\title{
Part 2. A MODEL OF THE GREAT LAGOON FOOD WEB
}

\section{Zbigniew Witek and Norbert Wolnomiejski}

\subsection{Introduction}

Mathematical models are becoming an indispensable tool in studies on complex ecological systems. Models make it possible to integrate a variety of information on the system and allow to control the consistency of the information. More importantly, such models provide better and deeper insights into the functioning of an ecosystem. Knowledge on mechanisms of functioning of ecosystems enhances their understanding and allows to predict their changes as well as to improve management of their resources. However, a mathematical ecosystem model has to be based on a sufficiently vast set of empirical data describing different components of habitats and communities in the ecosystem to be modelled.

The first attempt at a synthesis of knowledge on the functioning of the Szczecin Lagoon ecosystem based on research on different ecosystem components was made by Wiktor (1967). She described, in general terms, the food web structure of and the energy flow in the ecosystem, and assigned various groups of organisms to individual trophic levels. The rather low level of knowledge on the ecosystem and the early stage of ecosystem research methodology at that time prevented application of advanced analyses or quantitative assessments. Despite the subsequent continuous efforts to broaden the knowledge on habitats and communities of the Lagoon, the functioning of its entire ecosystem has not been tackled by researchers. Although descriptions of mathematical modelling of primary production and element cycling in the Szczecin Lagoon were published in the 2000s (Humborg et al., 2000; Wielgat, 2003; Wielgat and Witek, 2004), only the phytoplankton was considered, no other community component being taken into account.

It is becoming increasingly urgent to develop mathematical models of aquatic ecosystems not only for the sake of knowledge itself, but also for practical reasons. Overfishing observed in numerous fishing grounds worldwide and the frequently resultant elimination of the species exploited, advanced environmental degradation and irreversible biological damage (Marten, 1979; Sissenwine and Rosenberg, 1993; Fogarty and Murawski, 1998; Pauly et al., 1998; Clark, 2006) have led to realisation that the fisheries policy and governance 
have to be rooted in the ecosystem context. During the last two decades, the concept of the 'Ecosystem-Based Fishery Management' has been recognised worldwide (NMFS, 1999; Pikitch et al., 2004; FAO, 2005). The concept involves development of models as one of major activities indispensable for effective policy for sustainable management of aquatic ecosystems. The European Commission, too, has planned to reform the Common Fishery Policy in 2012 so that the knowledge base of legal regulations pertaining to fisheries is augmented by including the knowledge on the functioning of marine ecosystems (POSTNOTE, 2010).

The aim of this part of the study was to develop a static, mass-balance food web model of the central part of the Szczecin Lagoon (known as the Great Lagoon) based on a relatively large set of empirical data which could be collected in the area in 1998-2002, and which were described in the Part 1. Certain less or poorly known biotic components of the ecosystem required that the empirical data be supplemented by compilation of information found in the literature. The model may be treated as a starting point from which to develop more complex ecosystem-portraying tools which could aid decision making process involved in management of the area. The authors' intention was also to use the model to highlight those parts of the ecosystem the knowledge of which is still insufficient, and which require suitably planned, intensive studies.

\subsection{Description of the Model}

The food web of the Great Lagoon is described by a bottom-up static model, i.e., a model constructed starting from the bottom of the trophic pyramid up. A static mass-balance model is a system in which the internal structure of the community remains stable, the supply of matter/energy from the outside being balanced by the matter/energy losses and accumulation in the sediment. The organisms making up the Lagoon communities as well as the non-living organic matter were divided, for the purpose of the model, into trophic-functional categories generally termed the system components. These include also dead organisms (carcasses) and faeces. The matter/energy flow in the ecosystem was described by a matrix of trophic links between individual system components, energy budget equations, and a few additional simple formulae to describe sedimentation and export. The matter flow in the ecosystem was expressed in $\mathrm{gC} \mathrm{m}^{-2} \mathrm{yr}^{-1}$. The model, written in an MS Excel spreadsheet, can be easily modified or adjusted to specific conditions of other ecosystems.

System components. The model consists of three basic groups of components: autotrophs, heterotrophs, and different categories of non-living organic matter. A part of non-living organic matter is allochthonous. Autotrophs 
together with the allochthonous non-living organic matter constitute the first trophic level, that of producers, which lies at the base of the trophic pyramid. The primary production of the autotrophs and the magnitude of allochthonous organic matter supply are based in the model on empirical data and belong to the so-called model drivers. All the system components may be consumed by heterotrophs. The model estimates the secondary production of all heterotrophic components as well as the "production" of autochthonous non-living organic matter. It is the task of the model operator to adjust model coefficients so that the heterotrophic production the model estimates matches the values determined in direct empirical studies.

Matrix of trophic links. The matrix of trophic links determines how the production (or the supply from the outside) of each component is utilized within the ecosystem. Coefficients $F_{i j}$ define the part of the production (supply) of component $i$ utilised by component $j$ (by ingestion). To some extent, a component is allowed to utilise its own production (feeding on members of that component trophic-functional category). Selection of appropriate values of $F$ for individual system components is a basic task of the operator during model parameterization.

Live components, in addition to being susceptible to mortality caused by grazing or predation, may suffer additional 'natural' mortality not associated with feeding of other components, and produced by, e.g., autolysis, disease, senility etc. Dead organisms resulting from natural mortality (carcasses) are a separate component in the model. In the case of fishes, in addition to natural mortality, the model makes allowance for that caused by fishing.

Sedimentation, export and accumulation. In the pelagic compartment of the ecosystem, the part of phytoplankton production, allochthonous organic matter supply, dead organisms and faeces which have not been utilised by the remaining ecosystem components may be sedimented or exported (export being understood as removal and transfer from the Lagoon to the Pomeranian Bay). The phytoplankton sedimenting to the benthic part of the ecosystem, the deposited allochthonous organic matter, and the sinking dead organisms and faeces are treated by the model as separate system components available as food to the benthos, fishes and birds. The unused part of the production of all the remaining system components (bacterio- and zooplankton) the sedimentation of which is not allowed in the model is - in addition to natural mortality subjected to export only. In the benthic compartment of the ecosystem, the unused dead organisms, faeces, and the unused sedimented phytoplankton and allochthonous material are accumulated in the bottom sediments. It is only insect larvae that can be exported from the benthic compartment (via emergence of imagines). Fish migrations to/from other parts of the Odra river mouth system are not taken into account in the model. It is assumed instead that the emigration of fish from the Great Lagoon is counterbalanced by immigration 
of fish from outside of the Lagoon. Aquatic birds, the terminal links in the food web, spend a part of their lives outside the Lagoon's aquatic ecosystem and are treated by the model primarily as consumers; their production is regarded as exported from the ecosystem.

Energy budget equations. As already mentioned, the (net) primary production and the supply of allochthonous organic matter, making up the base of the trophic pyramid, have to be entered in the model as data from independent studies. The production $(P)$ of the remaining, heterotrophic system components is calculated from:

$$
P=C \times A E \times K_{2^{\prime}}
$$

where $C$ is the amount of food consumed; $A E$ is the food assimilation efficiency coefficient; and $K_{2}$ is the coefficient associated with the amount of assimilated food used for growth; it is also termed the net production efficiency. Consumption of component $j$ is a sum of products $F_{i j} \times P_{i}$ of all the food items ( $\left.i\right)$ of the component in question:

$$
C_{j}=\sum_{i=1}^{n}\left(F_{i j} \times P_{i}\right)
$$

where $n$ is the number of system components in the food of component $j$. Coefficients $A E$ and $K_{2}$ are parameters which have to be entered as data from independent studies. The knowledge of $C, A E$, and $K_{2}$ allows easy estimation of the remaining components of the energy budget, i.e., respiration $(R)$ :

$$
R=C \times A E \times\left(1-K_{2}\right)
$$

and the non-assimilated portion of food (faeces, FU):

$$
F U=C \times(1-A E)
$$

The system of energy budget equations is constructed by proceeding from the base of the trophic pyramid up towards its top. The food sources for the firstorder consumers are the primary production and the non-living organic matter.

System components feeding on representatives of their own group (withingroup consumption). Development of energy budget equations becomes somewhat complicated when system components feeding on representatives of their own trophic-functional category have to be dealt with. These include protists collectively treated as a single system component in which, e.g., numerous ciliates feed on heterotrophic flagellates and predatory ciliates feed on non- 
predatory ones. The within-group consumption is the case also in predatory fish. In such cases, to reflect the consumption of such system component in the model, only the food originating from other system components, $C_{n k^{\prime}}$ is taken into account so that:

$$
C_{j}=C_{n k}
$$

The consumption calculated this way is lower than the sum of consumption by all the elements (individuals) a system component contains. The production of such a component is calculated in the model as a sum of production based on food from both other system components $\left(P_{n k}\right)$ and from the system component in question $\left(P_{k}\right)$ minus consumption within the group $\left(C_{k}\right)$ :

$$
P_{j}=P_{n k}+P_{k}-C_{k}
$$

The production estimated this way is lower than the summary production of all the elements making up a given system component; it is the net production available as food to other system components. On the other hand, respiration and excretion of the unassimilated part of the food of a system component whose elements feed within their own category is equal to, respectively, summary respiration and summary excretion by all the elements of the component.

The coefficients $F_{i j}$ pertaining to within-group feeding $(i=j)$, are located along the diagonal of the trophic linkages matrix. Their meaning differs somewhat from that of all the remaining coefficients $F_{i j^{\prime}}$ as they denote a part of the production of component $i(=j)$ based on the food derived only from other system components, which is consumed by component $j(=i)$ :

$$
C_{j j}=C_{k}=F_{j j} \times P_{n k}
$$

Export of pelagic components. For objects passively floating in the water, export to the Pomeranian Bay (Exp) may be expressed as a ratio between water outflow $(Q)$ and concentration of a given system component. As the component's absolute biomass $(B)$ in the Lagoon is equal to the product of the Lagoon volume $(V)$ and the component's concentration, the export to biomass ratio is equal to the ratio between the outflow and the Lagoon volume:

$$
\operatorname{Exp} / B=Q / V
$$

By standardizing export by production of a given component, we get:

$$
\operatorname{Exp} / P=(Q / V) /(P / B) .
$$


It is worth noting that, even at a total lack of mortality, the production rate $(P / B)$ of the components floating passively in the water has to be higher than the water exchange ratio ( $Q / V)$. Should the opposite be the case, export would exceed production, whereby the component could not persist in the Lagoon.

Removal of individual objects from the Lagoon can be mediated by numerous agents. A higher density during the period of lower water outflow (e.g., in summer) and lower density during strong outflow (e.g., in winter) may, on the scale of one year, reduce losses produced by transport from the Lagoon compared to situations with stable flow and constant concentration of objects. In addition, export may be substantially modified by vertical migrations, whereby the objects (e.g., the zooplankton) during the day stay on or near the bottom, where the flow is reduced or is even directed opposite to that in the upper water layer.

Sedimentation. Equations describing sedimentation pertain to those system components which passively float in the water and do not resist gravitational settling (some phytoplankton, allochthonous particulate matter, faeces, remains of organisms). The bacterioplankton, zooplankton, and dissolved organic matter were assumed not to sediment. The equations define the part of production of a component not consumed in the water column (NC) which settles out $(S)$ to the benthic part of the ecosystem:

$$
S=N C \times k,
$$

where $k$ denotes the fraction subjected to sedimentation. The remaining part $(1-k)$ is exported. The coefficients $k$ should be entered into the model independently. Unfortunately, they are not easily amenable to measurements. In view of the lack of appropriate data, hypothetical values were assumed and fitted during model parameterization.

Iteration. As calculations of the amount of faeces and dead heterotrophs involve numerous feedbacks (because both faeces and dead organisms may be consumed by certain system components), it was necessary to carry out those calculations by iteration.

Results of calculations carried out by the model were checked by comparing the total matter supply and loss in the entire ecosystem. The supply consists of primary production of all autotrophic system components and the input of allochthonous organic matter. The loss consists of total respiration of all the living system components, export, catches, and accumulation in the sediment. The difference between the supply and the loss of matter should be zero.

Results of modelling. The basic results of model calculations are the magnitude of consumption $(C)$, production $(P)$, respiration $(R)$, amount of unassimilated food $(F U)$, additional mortality $(M)$, sedimentation $(S)$, accumulation in sediment (Acum), and export (Exp) of individual system components. In addition, the results of modelling include food composition of individual heterotrophic system 
components. Such data form a basis with which to estimate various ecological indicators describing the ecosystem under study.

Food composition. A table containing data on food composition of individual system components may be used as an auxiliary tool in model parameterization. The percent contribution of component $i$ to the diet of component $j\left(C \%_{i j}\right)$ is calculated from

$$
C \%_{i j}=\left(F_{i j} \times P_{i}\right) / C_{j} \times 100 .
$$

The food composition calculated by the model can be compared with results of independent studies, but the values of $C \%_{i j}$ cannot be directly changed. The food composition in the model can be modified only by appropriate selection of values of $F_{i j}$

Parameterization. The model is parameterized by adjusting the values of terms in energy budgets of individual system components, calculated by the model $\left(X_{m}\right)$ to the values produced by empirical studies $\left(X_{e}\right)$. This usually involves selection of $F_{i j}$ (or other parameters present in the model) such that the differences between the values compared do not exceed a preset level. The difference is measured by the relative error $(R E)$ expressed as a percentage:

$$
R E=\left(X_{m}-X_{e}\right) / X_{e} \times 100
$$

In this work, the differences were adjusted to the level below $1 \%$ of the empirical value $(R E<1 \%)$.

Production of invertebrates is an energy budget term which is easiest to determine independently of the model. Although production of aquatic ecosystem components is seldom measured directly, it is possible to determine production of numerous species indirectly, based on the empirically determined biomass $(B)$ and published $P / B$ ratios. The biomass of numerous components of the Great Lagoon biota, particularly that of the benthos (cf. Part 1), is relatively well known. In addition, there is ample literature (cited profusely in Part 1) on the $\mathrm{P} / \mathrm{B}$ ratios of various invertebrates inhabiting temperate fresh- and brackishwater areas. It should be mentioned that production of a component calculated from biomass $(B)$ and the $P / B$ ratio is the gross production (a sum of production of all the individuals in a given component of the food web); therefore, during parameterization, rather than comparing it with the net production calculated by the model, it is compared with gross production $\left(P_{g}\right)$ calculated as

$$
P_{g}=R \times K_{2} /\left(1-K_{2}\right)
$$

In the case of birds, rather than calculating the relative error of production, it was calculated for consumption determined by the model and by independent analyses. 
The knowledge on certain components of the Great Lagoon ecosystem proved too scant for empirical determination of their biomass or any element of energy budget. Such components include primarily pelagic, benthic, and periphytic bacteria, fungi, and protists. Their production could be estimated only tentatively from proportions between various components and from patterns known from other ecosystems. In those cases, the values of energy budget terms carry the highest load of uncertainty.

\subsection{The Great Lagoon Food Web}

\subsubsection{Defining the Food Web Components}

The structure of the Great Lagoon food web defined for the purpose of developing the model is based primarily on taxonomic groups and ecological formations identified in Part 1. However, in some cases the division was modified.

The entire phytoplankton was treated as a single component. The mesozooplankton was divided into rotifers, non-predatory cladocerans, and copepods as well as the predatory cladoceran Leptodora kindti, a species differing from the remaining mesozooplankton by its large body size, feeding mode, and importance as food for other organisms. The macrozooplankton was represented by the mysid Neomysis vulgaris. In addition, two other components, important for the functioning of the entire ecosystem, were defined in the pelagic compartment of the system: the bacterioplankton and the protozooplankton. Those microorganisms were not discussed in Part 1 due to the absence of relevant data from the Great Lagoon. However, they are extremely important in any aquatic ecosystem and cannot be ignored in a food web model. The macrophytes were divided into two components: 1) emergent plants, with stems protruding above the water surface, and 2) submerged plants, including those with floating leaves. The periphytic community on macrophytes was divided into phyto-, mesozoo-, and two categories of macrozooperiphyton: sessile and motile macrozooperiphyton. Despite the absence of relevant empirical data from the Great Lagoon, two additional components were defined within the periphyton: 1) periphytic bacteria and fungi, and 2) periphytic protists (protoperiphyton).

Among benthic invertebrates, the meiobenthos was treated as a single component, whereas the macrobenthos was divided into six groups: 1) Chironomus sp. larvae, 2) macrobenthic ostracods, 3) oligochaetes, 4) the zebra mussel (Dreissena polymorpha), 5) other molluscs, and 6) remaining zoobenthos including chironomid larvae other than those of Chironomus, larvae of other insects, crustaceans, hirudineans, hydracarids, etc. The majority 
of organisms grouped under the 'remaining zoobenthos' are littoral forms. Additionally, microbiological components were defined in the benthos as well: 1) microphytobenthos, 2) benthic bacteria and fungi, and 3) benthic protists, although no relevant quantitative data were available from the Great Lagoon. The microphytobenthos consists of unicellular and colonial algae inhabiting the littoral bottom; they are taxonomically and functionally very similar to the phytoperiphyton.

The fish fauna was divided into three categories: planktivores, benthivores, and predators, each being subdivided into two components, one consisting of larvae and fry, and the other composed of juveniles and adults. The final group included in the model are birds, treated as four components: herbivores, molluscivores, omnivores, and piscivores. Humans are a 'hidden' component of the food web, their contribution to the energy flow in the system being expressed only as a fish yield.

The food web includes also, as components, different forms of non-living organic matter. The model identifies three forms of allochthonous organic matter: 1) allochthonous dissolved organic matter (DOM), 2) allochthonous particulate organic matter (POM) in the water column, and 3) allochthonous organic matter settled out from the water column to the bottom sediment. In addition, some categories of autochthonous organic matter were defined. The pelagic compartment in the system supports two pools of autochthonous organic matter: faeces and remains of pelagic organisms. The benthic part contains four pools: 1) sedimented phytoplankton, 2) faeces of the benthos and faecal pellets sedimented from the water column, 3) animal remains, including those sedimented from the water column, and 4) remains of benthic and periphytic plants.

A total of 45 components were thus identified in the Great Lagoon food web (Fig. 2.1). Five components are autotrophic (phytoplankton, emergent macrophytes, submerged and floating leaved macrophytes, phytoperiphyton, and microphytobenthos), 31 components representing various functionaltrophic groups of heterotrophs (7 belonging to the plankton, 5 to the periphyton, 9 to the benthos, 6 to fish, and 4 to the waterfowl); the remaining 9 components cover non-living organic matter ( 3 and 6 involve allochthonous and autochthonous organic matter, respectively).

It has to be borne in mind that the division adopted cannot fully reflect the complexity of the Great Lagoon biota. Particularly simplified is the part of the food web situated close to the base of the trophic pyramid, as only the elementary trophic-functional categories were identified, without setting off some narrower, more specialised groups or individual fractions of non-living organic matter. The benthic macrofauna and top consumers, i.e. fish and birds, were treated in more detail, as the three animal groups are represented by half of the live system components. 


\section{Food web components}

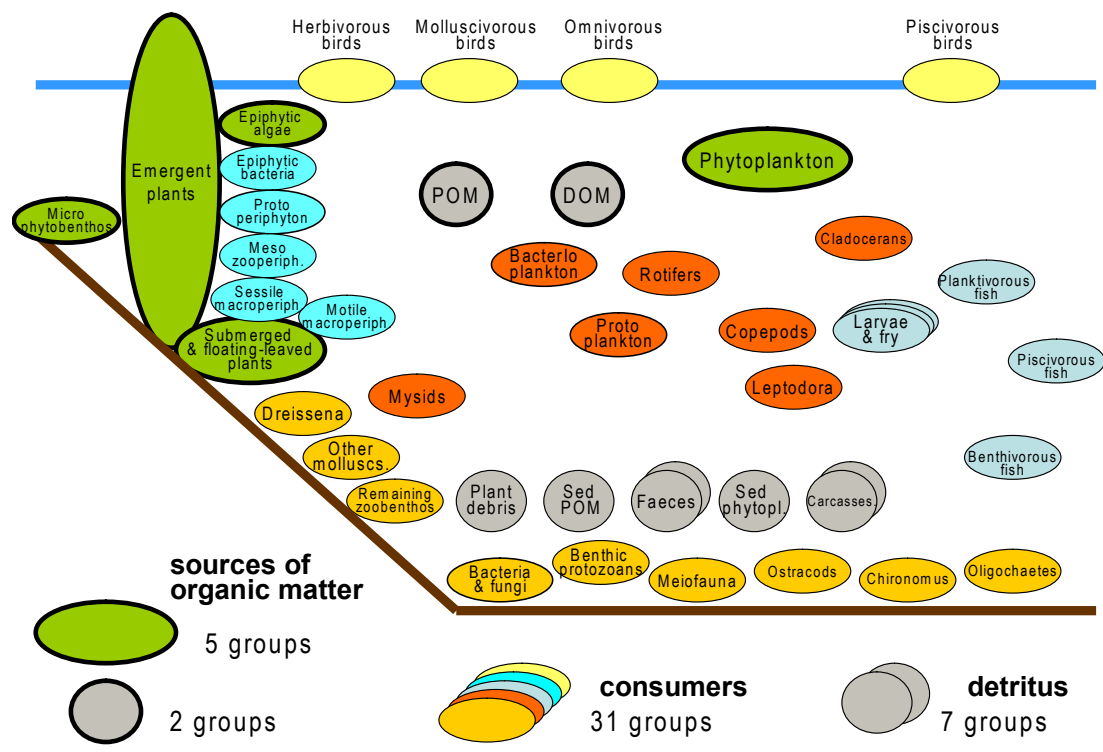

Figure 2.1 Components of the Great Lagoon (Szczecin Lagoon) food web. Components forming the source of organic matter to the ecosystem are marked with thick contours; grey-filled circles denote components composed of non-living organic matter.

\subsubsection{Bioenergetic Coefficients}

The energy budget of all the heterotrophic components of the food web required that bioenergetic coefficients $A E$ and $K_{2}$ be entered into the model for each group. As there are no published data on the values of those coefficients for organisms living in the Great Lagoon, the coefficients were derived from studies in other ecosystems. In the first place, the data collected in the Vistula Lagoon, an area ecologically similar to the Szczecin Lagoon, were used. In the Vistula Lagoon, bioenergetic analyses of the youngest developmental stages of certain fish species and the mysid Neomysis integer were carried out by Maciejewska and Margoński (2001), Maciejewska and Opaliński (2002; 2004; 2010) and Opaliński et al. (2004). Maciejewska and Opaliński (2010) reported values of $A E$ and $K_{2}$ for the youngest developmental stages of herring, smelt, three-spined stickleback, and perch. The food assimilation efficiency coefficient $(A E)$ was found to range within 0.40-0.69 (averaging 0.50), the net production efficiency coefficient $\left(K_{2}\right)$ ranging within 0.17-0.31 (averaging 0.26). Maciejewska and Opaliński (2002) 
supplied data necessary for determining $A E$ for $N$. integer. As shown by those data, food assimilation efficiency was similar between different size classes of the mysid and ranged within 0.66-0.81 (averaging 0.75). The corresponding values of the coefficients for other components of the Great Lagoon ecosystem had to be looked for in publications pertaining to other areas worldwide.

The literature contains very diverse estimates of food assimilation efficiency $(\mathrm{AE})$ and net production efficiency $\left(K_{2}\right)$, depending on age and conditions of the animals studied, type and abundance of food, temperature and other experimental conditions, and the measurement technique applied. Certain general patterns can only be derived from review papers. Based on data from dozens of publications, Valiela (1995) demonstrated food assimilation to depend largely on the type of food consumed (detritus, plants, animals). Although assimilation efficiency estimates of detritus, plants, and bacteria as food have covered a very wide range in the individual published studied (from a few to $100 \%)$, assimilation efficiency of detritus in most publications was reported as ranging from a few to about $60 \%$; assimilation efficiency of macrophytes ranged from 20 to $80 \%$, whereas unicellular organisms (bacteria, algae, yeasts) were assimilated with an efficiency of 40 to more than $80 \%$. In none of the publications was the assimilation efficiency of animal food lower than $40 \%$, most observations indicating more than $80 \%$. Based on those general patterns, for most of the system components whose diet relies on phytoplankton and bacteria, and much less so on animals and detritus, the model calculations assumed $A E=0.6(60 \%)$. $A E$ was assumed to be 0.7 for mysids (Maciejewska and Opaliński, 2002) and for benthivorous fish whose diet, in addition to animals, includes a substantial contribution of detritus. A lower $A E(0.4)$ was assumed for those components relying more on detritus or macrophytes. Based on Maciejewska and Opaliński (2010), AE for fish larvae and fry was assumed to be 0.5 . On the other hand, elevated $A E$ values were assumed for planktivores and piscivores (0.8-0.9). For bacteria and fungi, the model assumed $A E=1$, as the food assimilated is the food consumed by those organisms with external digestion (Table 2.1).

Utilisation of the assimilated food for growth $\left(K_{2}\right)$ and respiration in the animal world was reviewed by Humphreys (1979) who examined 235 energy budgets published by other authors for natural animal populations, both aquatic and terrestrial. He demonstrated that poikilotherms can be divided, in terms of their utilisation of food for growth, into 3 groups: fish and social insects, invertebrates (except insects), and non-social insects. Within those groups, terrestrial and aquatic animals did not differ in the degree to which they converted their food for growth. The highest average $K_{2}(40.7 \%)$ was typical of non-social insects (including those living in aquatic habitats); a lower average $K_{2}(25 \%)$ was shown by non-insect invertebrates, the lowest (9.77\%) being typical of fish and social insects. Non-insect invertebrates could be additionally subdivided into 
Table 2.1 Food assimilation efficiency $(A E)$ and net growth efficiency $\left(K_{2}\right)$ of heterotrophic components of the food web (based on energy units).

\begin{tabular}{|c|c|c|}
\hline Functional group: & $A E$ & $K_{2}$ \\
\hline \multicolumn{3}{|l|}{ Plankton: } \\
\hline Bacterioplankton & 1 & 0.33 \\
\hline Protozooplankton & 0.6 & 0.5 \\
\hline Rotifers & 0.6 & 0.3 \\
\hline Non-predatory cladocerans & 0.6 & 0.3 \\
\hline Copepods & 0.6 & 0.3 \\
\hline Leptodora kindti & 0.8 & 0.3 \\
\hline Mysids & 0.7 & 0.3 \\
\hline \multicolumn{3}{|l|}{ Periphyton: } \\
\hline Epiphytic bacteria and fungi & 1 & 0.33 \\
\hline Protozooperiphyton & 0.6 & 0.5 \\
\hline Mesozooperiphyton & 0.6 & 0.3 \\
\hline Sessile macrozooperiphyton & 0.8 & 0.3 \\
\hline Motile macrozooperiphyton & 0.6 & 0.3 \\
\hline \multicolumn{3}{|l|}{ Benthos: } \\
\hline Benthic bacteria and fungi & 1 & 0.33 \\
\hline Benthic protists & 0.6 & 0.5 \\
\hline Meiobenthos & 0.4 & 0.3 \\
\hline Chironomus sp. larvae & 0.6 & 0.4 \\
\hline Ostracods > $0.5 \mathrm{~mm}$ & 0.4 & 0.3 \\
\hline Oligochaetes & 0.4 & 0.3 \\
\hline Dreissena polymorpha & 0.6 & 0.3 \\
\hline Other molluscs & 0.6 & 0.3 \\
\hline Remaining zoobenthos & 0.6 & 0.4 \\
\hline \multicolumn{3}{|l|}{ Ichthyofauna: } \\
\hline Larvae and fry of planktivorous fish & 0.5 & 0.25 \\
\hline Juvenile and adult planktivorous fish & 0.8 & 0.2 \\
\hline Larvae and fry of benthivorous fish & 0.5 & 0.25 \\
\hline Juvenile and adult benthivorous fish & 0.7 & 0.2 \\
\hline Larvae and fry of piscivorous fish & 0.5 & 0.25 \\
\hline Juvenile and adult piscivorous fish & 0.9 & 0.2 \\
\hline \multicolumn{3}{|l|}{ Avifauna: } \\
\hline Herbivorous birds & 0.4 & 0.015 \\
\hline Molluscivorous birds & 0.4 & 0.015 \\
\hline Omnivorous birds & 0.8 & 0.015 \\
\hline Piscivorous birds & 0.9 & 0.015 \\
\hline
\end{tabular}


3 categories, depending on the type of food consumed: detritivores, showing the highest $K_{2}$ (averaging 36.2\%); carnivores, of intermediate net production efficiency $(27.6 \%)$, and herbivores showing the lowest efficiency (20.8\%). Like other homoiotherms, birds were characterised by a very low $K_{2}$ (averaging $1.29 \%)$.

Fish in Humphreys's (1979) study were represented by a relatively low amount of data (9 sets). Later on, in connection with rapid development of studies on trophic relationships among fishes, new compilations of bioenergetic information, based on larger data sets, were made available. One of the most popular sources is the FishBase web site (www.fishbase.org). The FishBase data show the food conversion for growth in fishes to be higher than that shown by Humphreys (1979). Values of $K_{1}$ which describe gross production efficiency (production to food consumption ratio, $P / C$ ) for fish species occurring in inland waters and in the Baltic were in most cases within 0.1-0.2. Values of $K_{2}$ that can be derived from those data, assuming $80 \%$ food assimilation efficiency, were ranging, in more than $75 \%$ of the data, within $0.1-0.3$ (10-30\%; median of $21 \%)$.

Neither the FishBase, nor the paper by Humphreys (1979) contain data on $\mathrm{K}_{2}$ of unicellular organisms (protists, bacteria). With regard to protists, there is a fairly convergent opinion that their net production efficiency is higher than that of invertebrates and fishes. Estimates published by Callow (1977), Khlebovich (1979), and Fenchel and Finlay (1983) ranged within 0.44-0.60. On the other hand, production efficiency of bacteria is lower. Schwaerter et al. (1988) estimated the average production efficiency of bacteria in lakes at $29 \%$, whereas Middelboe et al. (1992) arrived at an estimated $21-45 \%$ as the bacterial production efficiency in marine and coastal waters. Numerous authors pointed to a dependence of bacterial production efficiency on the nutrition value of the organic matter utilised by bacteria. At high C:N and C:P ratios in the organic matter, evidencing nitrogen- and phosphorus-deficient food, bacterial production may be minimal, the food used being almost entirely respired; on the other hand, at low C:N and C:P ratios in the organic matter, bacterial production efficiency may even exceed 40\% (Hopkinson et al., 1989; Coffin et al., 1993; Kuparinen and Heinanen, 1993).

Based on all those data, the model assumed a fairly simplified pattern of $K_{2}$ variation among heterotrophic components of the Great Lagoon food web (Table 2.1). $K_{2}=0.3$ was assigned to all the invertebrates, except insects. A higher efficiency was assigned to insects (0.4) and protists (0.5). The earliest developmental stages of fish as well as fish juveniles and adults received somewhat lowered values ( 0.25 and 0.2 , respectively). The lowest $K_{2}$ value was assigned to birds (0.015). The bacterial $K_{2}=0.33$ was entered to the model after initial parameterization, taking into account the assumed total community respiration in which bacterial respiration is the dominant component. 


\subsubsection{Compilation of Microbial Production Estimates in the Great Lagoon}

The microbiological literature concerning the Great Lagoon lacks references dealing with quantitative estimates of bacteria, protists or microalgae for 19982002, as well as for any other period. Therefore, microbial production had to be estimated based on studies conducted in other areas under similar climatic conditions.

Bacterioplankton. Bacterial production can be approximated using the review of Cole et al. (1988) who demonstrated that in the photic zone of both fresh and marine areas it amounts to about $20 \%$ of the average net phytoplankton production. In the Gulf of Gdańsk, Ameryk et al. (2005) estimated bacterial production at $14.3 \%$ of the gross phytoplankton production. Therefore, bacterial production in the Great Lagoon was assumed to amount to $80 \mathrm{gC} \mathrm{m}^{-2} \mathrm{yr}^{-1}$, i.e., $20 \%$ of the net primary production or $16 \%$ of the gross primary production. In addition to allochthonous and autochthonous non-living organic matter, phytoplankton production was the major food source for the bacterioplankton.

Protozooplankton. In the Baltic Sea and temperate lakes, the protozooplankton is made up by three major groups of unicellular organisms: ciliates, heterotrophic dinoflagellates, and nanoplanktonic heterotrophic flagellates (Azam et al., 1983; Fenchel, 1987; Witek et al., 1993; Wetzel, 2001). In the Gulf of Gdańsk, the annual production of planktonic ciliates was estimated at $4-5 \%$ of the gross phytoplankton primary production (Witek, 1998); the production of heterotrophic dinoflagellates and heterotrophic nanoflagellates was estimated at 5-6\% of the gross primary production and at $10-33 \%$ of the bacterial production, respectively (Witek, 1995). Studies on the protozooplankton conducted in brackish coastal lakes, the Gardno and the Łebsko, showed planktonic ciliates to be abundant and heterotrophic dinoflagellates to occur at much lower densities (Rychert et al., 2012). The potential ciliate production in the two coastal lakes was estimated by the authors referred to at $12-13 \%$ of the gross primary production. In Lake Michigan, the production of heterotrophic flagellates and ciliates corresponded to about $40 \%$ of the bacterial production (Carrick et al., 1992). Taking those data into account, the total protozooplankton production in the Great Lagoon was estimated at $50 \mathrm{gC} \mathrm{m}^{-2} \mathrm{yr}^{-1}$, which is equivalent to $10 \%$ of the gross phytoplankton primary production or about $60 \%$ of the bacterial production.

The protozooplankton in the Lagoon was assumed to feed primary on phyto- and bacterioplankton; in addition, feeding within the protozooplankton was regarded as relatively important, as heterotrophic flagellates of the protozooplankton are an important food sources for other protists, the ciliates. 
Microphytobenthos. Masses of live microalgae are found on large areas of the Lagoon's bottom, particularly on muds (Wolnomiejski et al., 2000). These are, however, mainly phytoplankton (particularly diatoms), sedimented upon the bottom or "glued" to the sediment surface. Some of them may return to the water column, resuspended by waves and currents. Except for most cyanobacteria, more than half of those sedimented algae contain live chloroplasts. Particularly well-retained chloroplasts were seen in coccal chlorophytes, indicating their survival, for a certain period of time, on the muddy bottom beyond the littoral zone. However, the only microalgae found exclusively on the muddy bottom of the main Lagoon basin were the cyanobacteria Phormidium tenue (Wolnomiejski et al., 2000).

The littoral supports a specific community of microalgae forming the so-called biofilm or a microbiotic sediment layer which constitute an additional, substantial pool of organic matter on the bottom and produce various substances (mainly polysaccharides and proteins) consolidating the sediment particles (Johnson et al., 1989; Madsen et al., 1993; McLusky and Elliott, 2004). Unfortunately, those microalgae in the Great Lagoon have not been studied. Owing to the potential importance of benthic microalgae for primary production, particularly on the shallow bottom (e.g. Wasmund and Kowalczewski, 1982; Graneli and Sundbäck, 1986), even theoretical estimates of microalgal production merit inclusion into food web characterisation.

To arrive at a hypothetical estimate of microphytobenthos production, a compilation can be made from published information and from the authors' own observations and assumptions as to the role of sediment type, the presence of macrophytes and zebra mussel beds, exposure of the bottom to destructive effects of wave action etc., which will theoretically determine what part of the bottom is amenable for colonisation by and capable of supporting the microphytobenthos. The following major premises were taken into account:

- photic zone depth - Secchi disk visibility relationships (Kajak, 2001);

- bottom area amenable to colonisation by and development of strictly benthic microalgae in the Great Lagoon; this area is about $120 \mathrm{~km}^{2}$ $\left(40 \mathrm{~km}^{2}\right.$ of the unvegetated littoral bottom, $60 \mathrm{~km}^{2}$ of the phytolittoral bottom, and $20 \mathrm{~km}^{2}$ of bottom in embayments, within 2-4 $\mathrm{m}$ depth range);

- an opinion expressed by McLusky and Elliott (2004) that the production of estuarine microphytobenthos may be similar to that of the phytoplankton in the water column overlying the bottom supporting the microphytobenthos in question;

- opinions of other authors quoted by Wetzel (2001) that phytoplankton production among the littoral vegetation drops by an average of $42 \%$ (by more than $50 \%$ among pondweed) due to shading, $\mathrm{CO}_{2}$ and nutrient deficiency, and the release of plant inhibitors (mainly polyphenolic compounds) by macrophytes. 
A compilation based on the premises listed above yields a microphytobenthos production estimate of ca. $35 \mathrm{gC} \mathrm{m}^{-2} \mathrm{yr}^{-1}$.

Another way of estimating that production may involve a relationship developed by Boulion (2004a) in his review paper on primary production estimation in littoral and open parts of various lakes in the temperate zone of the northern hemisphere. He found the microphytobenthos production $\left(\mathrm{PP}_{\text {mphb }}\right)$ to be a function of the proportion of littoral in the surface area of the entire lake $\left(\mathrm{A}_{\text {litt }} / \mathrm{A}_{\text {lake }}\right)$ and the phytoplankton production $\left(\mathrm{PP}_{\text {phpl }}\right)$, which can be described by the equation:

$$
P P_{\text {mphb }}=0.32 \times A_{\text {litt }} / A_{\text {lake }} \times P P_{\text {phpl }}
$$

Assuming the littoral surface area to account for $25 \%$ of the Great Lagoon bottom, and the net phytoplankton production to be $400 \mathrm{gC} \mathrm{m}^{-2} \mathrm{yr}^{-1}$, the microphytobenthos production was estimated at $32 \mathrm{gC} \mathrm{m}^{-2} \mathrm{yr}^{-1}$. This value was used in the Great Lagoon food web model.

Benthic bacteria and fungi. The production of benthic bacteria and fungi in the Great Lagoon has not been studied so far. However, Cole et al. (1988) assessed the relationship between bacterial production and sediment organic carbon content. Their analysis was based on data collected in riverine and coastal marine ecosystems. The relationship was described with the equation:

$$
\log (S B P)=0.69 \times \log (S O C)-0.15 \quad\left(r^{2}=0.66\right),
$$

where SBP is the sedimentary bacteria production $\left(\mu \mathrm{gC}_{\text {d.w. }^{-1}} \mathrm{~d}^{-1}\right)$ and SOC is the sediment organic carbon content $\left(\mathrm{mgC}_{\mathrm{d} . \mathrm{w}}{ }^{-1}\right)$.

According to Osadczuk (2004), organic matter accounted for an average of $9.1 \%$ of dry weight of the silty fraction $(<63 \mu \mathrm{m})$ in the Szczecin Lagoon's muddy sediments, and for $5.9 \%$ of that fraction in sandy sediments. The silty fraction in the muddy and sandy sediments averaged 84.9 and $22 \%$ of the total sediment weight, respectively. The organic carbon content calculated from these data amounted to $7.7 \%\left(77 \mathrm{mgC}_{\text {d.w. }}{ }^{-1}\right)$ and $1.3 \%\left(13 \mathrm{mgC}_{\text {d.w. }}{ }^{-1}\right)$ of the total sediment weight in the muddy and sandy sediments, respectively. Using the equation developed by Cole et al. (1988) shown above, the bacterial production rate in the Great Lagoon can thus be estimated at about 14 and $4 \mu \mathrm{gC} \mathrm{g}_{\text {d.w. }}{ }^{-1} \mathrm{~d}^{-1}$ in the muddy and sandy sediments, respectively.

Information on bacterial production normalised to $1 \mathrm{~g}$ sediment dry weight cannot be, in a straightforward manner, utilised in estimates of production per unit bottom surface of a lagoon. It is necessary to know the 
amount of dry sediment per unit surface in a layer of a certain thickness. The amount of dry sediment per $1 \mathrm{~m}^{2}$ bottom can be expressed as:

$$
D M=10000 \times h \times B D \times(100-W) / 100,
$$

where: DM, sediment dry weight $\left(\mathrm{g} \mathrm{m}^{-2}\right)$,

h, sediment layer thickness $(\mathrm{cm})$

$\mathrm{BD}$, sediment bulk density $\left(\mathrm{g} \mathrm{cm}^{-3}\right)$,

$\mathrm{W}$, sediment moisture content (\% wet weight).

Sediment bulk density depends on the moisture content as well as on contents of organic and mineral matter. Assuming an approximately identical density of water and organic matter (about $1 \mathrm{~g} \mathrm{~cm}^{-3}$ ), and setting the mineral density at about $2.6 \mathrm{~g} \mathrm{~cm}^{-3}$, the sediment bulk density can be calculated as:

$$
B D=260 /(100+1.6 \times(W+O M-W \times O M / 100))
$$

where OM is the organic matter content (\% sediment dry weight).

The mean organic matter content in the silty fraction of the muddy and sandy sediments in the Szczecin Lagoon was estimated at 23.3 and $14.4 \%$ dry weight, respectively (Osadczuk, 2004). This yields 19.8 and $3.2 \%$ of the total sediment weight, respectively. No data on the Great Lagoon moisture content were found in the available literature. According to Graca et al. (2006), the moisture content of silty-clayey and clayey-silty sediments of the Gulf of Gdańsk ranged within $55-90 \%$, the sandy sediment most frequently showing the moisture content of $15-30 \%$. Assuming an average moisture content of muddy sediments of $70 \%$ and organic matter content of $20 \%$, the sediment bulk density can be assumed as about $1.2 \mathrm{~g} \mathrm{~cm}^{-3}$. Following such assumptions, a $1 \mathrm{~cm}$ thick layer of muddy sediment on $1 \mathrm{~m}^{2}$ bottom surface would contain about $3.5 \mathrm{~kg}$ sediment dry weight. On the sandy bottom of an average moisture content of $25 \%$ and organic matter content of $3 \%$, the sediment bulk density can be estimated at about $1.8 \mathrm{~g} \mathrm{~cm}^{-3}, 1 \mathrm{~cm}$ thick sediment layer of $1 \mathrm{~m}^{2}$ bottom surface containing $13.5 \mathrm{~kg}$ sediment dry weight. Before these data can be used to estimate the annual bacterial production, it is necessary to make further assumptions, this time with regard to the thickness of the biologically active sediment layer and depth distribution of bacterial production in the sediment. For example, at a 1-5 cm thick active layer and average annual bacterial production rate in this layer of 14 and $4 \mu g \mathrm{~g} \mathrm{~g}_{\text {d.m. }}{ }^{-1} \mathrm{~d}^{-1}$ in the muddy and sandy sediments, respectively, a similar annual bacterial production can be expected in both sediment types (18-100 $\left.\mathrm{gC} \mathrm{m}^{-2} \mathrm{yr}^{-1}\right)$. As the above estimates are very tentative and the expected annual production range is very wide, the sediment bacterial and fungal production have not been adjusted in the model to any concrete level. 
It was assumed that the sediment bacteria and fungi feed on all the forms of non-living organic matter and sedimented phytoplankton, present in the bottom deposits.

Benthic protists. The lack of local studies and the paucity of literature information on benthic protists made it impossible to estimate their production without using the model. The protozoobenthic organisms were assumed to feed on the sedimented phytoplankton, sediment-dwelling bacteria and fungi as well as on organic remains and faeces.

Periphytic bacteria, fungi, and protists. The absence of empirical and literature data on periphytic microorganisms, too, made it impossible to assess their production in the Great Lagoon without the recourse to the model. It was assumed that periphytic bacteria and fungi feed mainly on phytoperiphyton and dead tissues of macrophytes serving as substrate, whereas periphytic protists feed mainly on phytoperiphyton and periphytic bacteria and fungi; fine particles in suspension, containing phyto- and bacterioplankton as well as non-living organic matter, contribute to the diet as well.

\subsubsection{Primary Production and the Supply of Allochthonous Organic Matter}

Organic matter in an ecosystem originates from the autotrophic primary production and is also supplied from the outside of the system. Part 1 discussed production of different autotrophic system components in the Great Lagoon in 1998-2002. Those data were used as drivers in the model described in this part.

The gross primary production (GPP) of the phytoplankton was estimated at $500 \mathrm{gC} \mathrm{m}^{-2} \mathrm{yr}^{-1}$. Assuming the phytoplankton respiration to use up 20\% GPP, the net primary production was estimated at $400 \mathrm{gC} \mathrm{m}^{-2} \mathrm{yr}^{-1}$. A similar GPP loss on respiration was assigned to the remaining groups of aquatic plants, except helophytes (Table 2.2). In the latter, with their leaves and upper part of the stem protruding from the water, most of the gas exchange proceeds in the atmosphere. It was therefore assumed that helophyte respiration in water accounts for as little as $1 / 4$ of the total respiration, therefore the helophyte stipulated GPP in the water was assumed to be about $75.5 \mathrm{gC} \mathrm{m}^{-2} \mathrm{yr}^{-1}$.

The major supplier of allochthonous organic matter to the Great Lagoon is the River Odra. The annual supply with the Odra discharge can be estimated from monitoring data of the Regional Inspectorate of Environmental Protection (RIEP) in Szczecin. The average annual supply in 1998-2002, as determined for the Krajnik Dolny monitoring site, was slightly above 230 thou. tC $\mathrm{yr}^{-1}$ (Anon., 19912003). The RIEP data do not distinguish between the soluble and particulate fractions of organic matter. Analyses performed in River Vistula, where the two 
fractions were distinguished between, showed the dissolved fraction to account for $60 \%$ of the total organic matter load discharged by the river into the Baltic, the remaining part consisting of the particulate fraction (Pempkowiak and Kupryszewski, 1980). Assuming similar proportions for the Odra, the dissolved organic carbon (DOC) load discharged by the Odra in the Lagoon in 1998-2002 may be estimated at about 138 thou. $\mathrm{tC}^{\mathrm{yr}^{-1}}$.

However, it cannot be assumed that the entire particulate organic carbon (POC) load transported by the Odra and recorded at Krajnik Dolny reaches the Lagoon. The Krajnik Dolny site is located about $70 \mathrm{~km}$ away upstream from the Odra mouth. Along this section, the river flow slows down and the bed forks out to two branches: the Eastern and the Western Odra, the branches being connected with a system of transverse canals and wetlands. The Eastern Odra passes through Lake Dąbie before it reconnects with the Western Odra to form a common mouth area (the Roztoka Odrzańska) in the southern part of the Szczecin Lagoon. Nowak (1980) calculated that as little as 30\% of the suspended particulates transported by the Odra upstream of the forking point reaches the Szczecin Lagoon, the remaining $70 \%$ being sedimented out en route. Assuming those proportions to hold, the POC load discharged by the Odra into the Lagoon in 1998-2002 can be estimated at somewhat less than 28 thou. $\mathrm{tC}^{\mathrm{yr}} \mathrm{r}^{-1}$.

The city of Szczecin is an additional source of organic matter for the Lagoon. In the period covered by this study, the city's wastewater management was in a very bad shape. In 2001, of about 90 sewage outlets, only 2 were equipped with mechanical and biological sewage treatment devices (Jurkowski et al., 2003). In his report on the Szczecin Lagoon water quality, Mutko (1994) referred to the 1985 data showing the contribution of municipal and industrial sewage from the city of Szczecin to the total organic pollution in the Szczecin Lagoon to be estimated at about $24 \%$. Assuming this contribution and rounding it up to $25 \%$ to include sewage discharged by other settlements situated along the Lagoon shores, it can be demonstrated that, with the Odra's organic load identical to that in 1998-2002, the municipal and industrial wastes could have contributed additional 55 thou. tC $\mathrm{yr}^{-1}$. Assuming an even 50\% reduction of that load as a result of diminution of total wastewater production and progress in sewage treatment in 1985-2000, the total organic load from municipal and industrial sources can be estimated at about 27 thou. tC $\mathrm{yr}^{-1}$.

The total organic matter supply to the Great Lagoon in 1998-2002 may be thus estimated at about 193 thou. tC $\mathrm{yr}^{-1}$, about 152 thou. $\mathrm{tC} \mathrm{yr}^{-1}$ of which were supplied in the dissolved form, 41 thou. $\mathrm{tC} \mathrm{yr}^{-1}$ being contained in suspended particulates (assuming the DOC:POC ratio of 1:1 in the organic matter of municipal and industrial origin). When related to the Great Lagoon surface area $\left(410 \mathrm{~km}^{2}\right)$, the organic matter supply amounts to about $370 \mathrm{~g} \mathrm{DOC} \mathrm{m}^{-2} \mathrm{yr}^{-1}$ and about $100 \mathrm{~g} \mathrm{POC} \mathrm{m}^{-2} \mathrm{yr}^{-1}$, the combined value being comparable with the Lagoon's primary production (Table 2.2 ). 
Table 2.2 Sources of organic matter in the Great Lagoon in 1998-2002.

\begin{tabular}{|l|c|c|}
\hline Organic matter source & $\begin{array}{c}\text { gross } \\
{\left[g C \mathbf{~ m}^{-2} \mathbf{y r}^{-1}\right]}\end{array}$ & $\begin{array}{c}\mathbf{n e t} \\
{\left[g^{-2} \mathbf{~}^{-1}\right]}\end{array}$ \\
\hline Primary production of phytoplankton & 500 & 400 \\
\hline Primary production of emergent macrophytes & 75.5 & 71.7 \\
\hline $\begin{array}{l}\text { Primary production of submerged and floating-leaved } \\
\text { macrophytes }\end{array}$ & 14.5 & 11.6 \\
\hline Primary production of microphytobenthos & 40 & 32 \\
\hline Primary production of epiphytic algae & 27.5 & 22 \\
\hline Supply of allochthonous particulate organic matter (POM) & & 100 \\
\hline Supply of allochthonous dissolved organic matter (DOM) & & 370 \\
\hline
\end{tabular}

The sum total of gross primary production of all the autotrophic components of the Great Lagoon ecosystem in 1998-2002 was estimated at $658 \mathrm{gC} \mathrm{m}^{-2} \mathrm{yr}^{-1}$, the supply of allochthonous organic matter being estimated at $470 \mathrm{gC} \mathrm{m}{ }^{-2} \mathrm{yr}^{-1}$; thus the total input to the ecosystem was $1128 \mathrm{gC} \mathrm{m}^{-2} \mathrm{yr}^{-1}$. However, consumers are capable of utilising the net primary production only (537 $\mathrm{gC} \mathrm{m}^{-2} \mathrm{yr}^{-1}$ ), for which reason the true organic matter supply to the heterotrophic part of the system was about $1000 \mathrm{gC} \mathrm{m}^{-2} \mathrm{yr}^{-1}$. Almost half of that supply (47\%) was in the form of allochthonous organic matter, $40 \%$ were contributed by the phytoplankton production, $8 \%$ by macrophytes, the remaining $5 \%$ being contributed by production of the microphytobenthos and phytoperiphyton.

\subsubsection{Production of Heterotrophic Components, Used in Model Parameterization}

As already mentioned in the section describing the model, it processes all organic matter fluxes in the ecosystem on an annual basis. Production of most heterotrophic ecosystem components was estimated in Part 1, based primarily on the biomass averaged for the growing season (210 days, from April through October) and seasonal P/B values. When estimated by multiplying the average seasonal biomass by the seasonal $P / B$, the production value in fact represented that of the growing season. A possible discrepancy between the annual and the growing season production may introduce certain inaccuracy to the model. In autumn-winter (NovemberMarch), when water temperature is usually lower that $5{ }^{\circ} \mathrm{C}$, life processes of poikilotherms slow considerably down, and some species (e.g. numerous copepods: Bosselmann, 1975; Alekseev, 1987) enter the diapause state. Under such conditions, the assumption of the annual production being equal 
to that of the growing season does not err too much. However, certain species continue growing also after the growing season has terminated, as evidenced by, e.g., the development of a winter generation of Chironomus plumosus in Lake Jeziorak (Giziński and Wiśniewski, 1971). In those cases, the annual production is higher than that during the growing season. Another sources of error in production estimates from seasonal values of biomass and P/Bs may be sought in differences between the length of the growing season used in the in biomass estimates and in the P/B estimates. In the temperate zone, depending on climatic conditions (and also on resources in a researcher's disposal), the field season can take from 6 to 12 months during a year. If, for example, the production estimate is based on the biomass averaged over a period shorter than that used for the P/B estimate, the biomass may easily be relatively higher than that estimated over a longer period of time, covering more autumn-winter months, because biomass of numerous aquatic organisms (e.g., rotifers, cladocerans) decreases in autumn-winter. Then the production will be ultimately overestimated. Such inaccuracies are difficult to avoid in a compilation-based work, but the interpretation of modelling results has to take into account a possibility of such errors.

Table 2.3 summarises production estimates for those heterotrophic system components for which it was calculated in Part 1 or estimated in Section 2.3.3 above. All the production estimates were treated as annual values, production of each system component being understood here as a sum total of production of all the individuals making up the component. These production estimates were used to parameterize the model.

The highest production in the plankton was typical of bacteria and protists (80 and $50 \mathrm{gC} \mathrm{m}^{-2} \mathrm{yr}^{-1}$, respectively). Their respective production was an order of magnitude higher than the production of mesozooplanktonic components (rotifers, cladocerans, and copepods; $1-13 \mathrm{gC} \mathrm{m}^{-2} \mathrm{yr}^{-1}$ ). Owing to the lack of reliable biomass data, production of mysids was not included in the table.

Production values of the mesozooperiphyton, sessile and motile macrozooperiphyton were similar (0.8-2.8 $\left.\mathrm{gC} \mathrm{m}^{-2} \mathrm{yr}^{-1}\right)$ and indicative of a several-fold lower production of zooperiphyton, compared with production of the zooplankton or that of the zoobenthos. The lack of appropriate data made it impossible to estimate the production of periphytic bacteria and protists without the assistance of the model.

In the benthic community, production of the meiofauna $\left(16 \mathrm{gC} \mathrm{m}^{-2} \mathrm{yr}^{-1}\right)$ was only slightly lower than that of the total macrozoobenthos ( $\left.22 \mathrm{gC} \mathrm{m}^{-2} \mathrm{yr}^{-1}\right)$. A distinct component of the latter was Chironomus sp. the production of which (11.7 $\mathrm{gC} \mathrm{m}^{-2} \mathrm{yr}^{-1}$ ) was several times higher than production of any of the remaining components (0.6-3.7 $\left.\mathrm{gC} \mathrm{m}^{-2} \mathrm{yr}^{-1}\right)$. Production of benthic bacteria and protists could not be estimated without the recourse to the model. 
Table 2.3 Secondary production in the Great Lagoon in 1998-2002, estimated from field observations and theoretical assumptions. Production of each component is considered here to be the sum total of production of all individuals contributing to the component.

\begin{tabular}{|c|c|}
\hline Food web component & $\begin{array}{l}\text { Production } \\
{\left[\mathrm{gC}^{-2} \mathrm{yr}^{-1}\right]}\end{array}$ \\
\hline \multicolumn{2}{|l|}{ Plankton: } \\
\hline Bacterioplankton & 80 \\
\hline Protozooplankton & 50 \\
\hline Rotifers & 5.95 \\
\hline Non-predatory cladocerans & 13.01 \\
\hline Copepods & 5.48 \\
\hline Leptodora kindti & 1.28 \\
\hline \multicolumn{2}{|l|}{ Periphyton: } \\
\hline Mesozooperiphyton & 2.75 \\
\hline Sessile macrozooperiphyton & 0.80 \\
\hline Motile macrozooperiphyton & 1.30 \\
\hline \multicolumn{2}{|l|}{ Benthos: } \\
\hline Meiofauna & 16.30 \\
\hline Chironomus sp. larvae & 11.71 \\
\hline Oligochaetes & 2.43 \\
\hline Macrobenthic ostracods & 0.60 \\
\hline Dreissena polymorpha & 3.70 \\
\hline Other molluscs & 0.60 \\
\hline Remaining zoobenthos & 3.39 \\
\hline \multicolumn{2}{|l|}{ Ichthyofauna: } \\
\hline Larvae and fry of planktivorous fish & 0.17 \\
\hline Juvenile and adult planktivorous fish & 0.32 \\
\hline Larvae and fry of benthivorous fish & 1.01 \\
\hline Juvenile and adult benthivorous fish & 1.91 \\
\hline Larvae and fry of piscivorous fish & 0.41 \\
\hline Juvenile and adult piscivorous fish & 0.63 \\
\hline
\end{tabular}


Among the system components representing adult and juvenile fish, the highest production ( $1.9 \mathrm{gC} \mathrm{m}^{-2} \mathrm{yr}^{-1}$ ) was typical of benthivorous fish. In contrast, production of the planktivorous fish was low (about $0.3 \mathrm{gC} \mathrm{m}^{-2} \mathrm{yr}^{-1}$ ), whereas production of predatory fish corresponded to $1 / 3$ of the benthivore production (in excess of $0.6 \mathrm{gC} \mathrm{m}^{-2} \mathrm{yr}^{-1}$ ). Noteworthy is the substantial production of larvae and fry, estimated jointly for all the fish categories at about $1.6 \mathrm{gC} \mathrm{m}^{-2} \mathrm{yr}^{-1}$.

With regard to the waterfowl, the model was parameterized with their annual consumption (Table 2.4 ) rather than annual production. The consumption values estimated for herbivorous, molluscivorous, and piscivorous birds were similar, from 0.15 to $0.20 \mathrm{gC} \mathrm{m}^{-2} \mathrm{yr}^{-1}$, consumption of omnivores being lower by 2 orders of magnitude $\left(0.002 \mathrm{gC} \mathrm{m}^{-2} \mathrm{yr}^{-1}\right)$, but only with respect to the food originating directly in the Lagoon. As mentioned in Part 1, the omnivorous birds (gulls, terns) obtain a large part of their food outside of the Lagoon ecosystem (at garbage dumps, in town, etc.).

Table 2.4 Food consumption of avifauna in the Great Lagoon, estimated from field observations and theoretical assumptions.

\begin{tabular}{|l|c|}
\hline Birds' trophic group: & $\begin{array}{c}\text { Consumption } \\
\mathbf{g C ~}^{-2} \mathbf{~} \mathbf{r}^{-1}\end{array}$ \\
\hline Herbivorous birds & 0.163 \\
\hline Molluscivorous birds & 0.149 \\
\hline Omnivorous birds & 0.002 \\
\hline Piscivorous birds & 0.203 \\
\hline
\end{tabular}

\subsubsection{Export of Pelagic Ecosystem Components to the Pomeranian Bay}

Transport of planktonic ecosystem components to the Pomeranian Bay was estimated based on the assumptions discussed in Section 2.2. Assuming the water outflow to the Pomeranian Bay $(Q)$ to be balanced out by the sum total of riverine inflow and to average $18.4 \mathrm{~km}^{3} \mathrm{yr}^{-1}$, and approximating the Great Lagoon volume $(V)$ at $1.6 \mathrm{~km}^{3}$, the water exchange rate $(Q / V)$ in the Great Lagoon can be estimated at about $11.5 \mathrm{yr}^{-1}$. As the concentration of planktonic organisms is strongly season-dependent, and during the growing season (April-October) is usually several-fold higher than at other times, export of plankton varies as well and peaks during the growing season. The outflow in 
April-October amounts to about 50\% of the annual outflow (Majewski, 1980). Some planktonic organisms (cladocerans, copepods, Leptodora) spend about half of the diurnal cycle near the bottom, away from the main current. It may be thus assumed, for simplicity, that the effective volume of water exporting the plankton $\left(Q_{-}\right)$equals only half, or even $1 / 4$, of the total volume of water outflowing from the Lagoon. The part of the planktonic production that is exported $($ Exp/P) can be calculated as:

$$
\operatorname{Exp} / P=\left(Q_{e} / Q\right) \times(Q / V) /(P / B)
$$

Table 2.5 lists the parts of planktonic production exported, as estimated based on the premises described above.

Table 2.5 Estimation of the proportion of pelagic production exported from the Great Lagoon. $\mathrm{P} / \mathrm{B}$, annual production/biomass ratio; $Q_{-} / Q_{-}$, part of the outflow effectively transporting plankton; Exp/P, part of production exported. The Lagoon volume $V=1.6 \mathrm{~km}^{3}$; the total water outflow $Q=18.4 \mathrm{~km}^{3} \mathrm{yr}^{-1}$

\begin{tabular}{|l|c|c|c|}
\hline Functional group: & P/B & O-/Q & Exp/P \\
\hline Phytoplankton & 75 & 0.5 & 0.077 \\
\hline Bacterioplankton & $50^{\mathrm{a}}$ & 0.5 & 0.115 \\
\hline Protozooplankton & $150^{\mathrm{b}}$ & 0.5 & 0.038 \\
\hline Rotifers & 60 & 0.5 & 0.096 \\
\hline Non-predatory cladocerans & 27 & 0.25 & 0.106 \\
\hline Copepods & 10 & 0.25 & 0.288 \\
\hline Leptodora kindti & 15 & 0.25 & 0.192 \\
\hline
\end{tabular}

a guess estimate (compare with annual average P/B of bacterioplankton in Lake Constance, Germany $=0.13 \mathrm{day}^{-1}$ (Straile, 1998 in Wetzel, 2001))

${ }^{b}$ guess estimate (compare with P/B of combined heterotrophic nanoflagellates and ciliates in the Gulf of Gdańsk (the Baltic Sea) = $149 \mathrm{yr}^{-1}($ Witek, 1995))

Mysids were assumed to be capable of resisting the outflowing current, therefore their passive export was not included. Mysids are even known of arriving to the Lagoon from the Pomeranian Bay (cf. Section. 1.14.4).

In addition to live ecosystem components (the plankton), non-living organic matter is exported as well. It was assumed that the entire DOM load not used in the water column is exported to the Pomeranian Bay. With respect to POM (allochthonous POM, faeces, detritus), $90 \%$ of its remains not utilised by consumers were arbitrarily regarded as sedimenting to the bottom $(k=0.9)$, the remaining $10 \%$ being exported to the Pomeranian Bay. 


\subsubsection{Directions of Matter and Energy Flows in the Ecosystem of the Lagoon}

The model operator's basic task when calibrating the model was to select the $F_{i j}$ values which would form the matrix of trophic connections and define proportions at which the production of various food web components would be utilised by consumers (Tables 2.5 - 2.11). It was also necessary to determine the fate (export, natural mortality, fishing, etc.) of that part of the production which was not utilised by consumers. The parameterization procedure was started with components forming the basis of the trophic pyramid, and proceeded along the matter flux direction towards the top of the pyramid. The $F_{i j}$ indices are rarely directly determined, and were not dealt with in any study focusing on the Szczecin Lagoon or on other Baltic coastal water bodies. Estimation of $F_{i j}$ values is, on the other hand, aided by results of research on food composition and food rations of aquatic organisms. In the Great Lagoon, such studies were conducted with respect to some fish species (Wolnomiejski and Grygiel, 1994b; 1994C; 2002) and Chironomus sp. larvae (Wolnomiejski et al., 2000). For the remaining aquatic organisms, relevant were studies carried out in other, similar ecosystems, and the theoretical knowledge. Thus, the extent to which production of individual ecosystem components was utilised was estimated by successive approximations in which the values of $F_{i j}$ were selected so that production, food composition, catches (landings), export etc. of possibly largest number of components corresponded to production, food composition etc. determined from empirical data or from theoretical knowledge. Effort was made not to violate the matter conservation principle. It should be realised that, at a high number of all the theoretically possible trophic links between food web components and their scalar nature, there is an infinite number of possible trophic link matrices which would reflect the reality more or less accurately. The picture proposed in this work represents the current knowledge and the authors' intuitions. As new data are collected in the future, and as the knowledge on ecosystems of the type represented by the Great Lagoon increases, the picture is likely to be modified and refined.

\subsubsection{Utilisation of Plankton Production and Non-living Organic Matter Supply in the Water Column}

The trophic link matrix developed from the selection of $F_{i j}$ values shows the phytoplankton production to be utilised to the highest degree (20 and 25\%) by the bacterio- and protozooplankton, respectively, the metazoan zooplankton utilising a somewhat lower fraction (about 17\%) (Table 2.6). Almost $1 / 5$ of the 
Table 2.6 Utilisation of phytoplankton primary production and non-living organic matter supply in the pelagic compartment. Values in each column add up to 1.

\begin{tabular}{|c|c|c|c|c|c|}
\hline PRODUCER OR FOOD SOURCE & 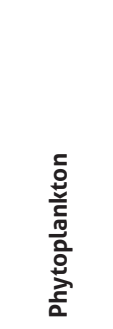 & 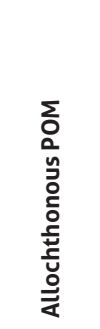 & 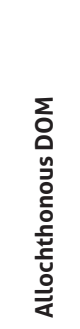 & 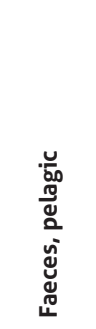 & 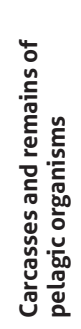 \\
\hline \multicolumn{6}{|l|}{ Plankton: } \\
\hline Bacterioplankton & 0.2 & 0.2 & 0.22 & 0.4 & 0.45 \\
\hline Protozooplankton & 0.25 & 0.05 & & 0.05 & 0.07 \\
\hline Rotifers & 0.04 & 0.0009 & & 0.005 & 0.007 \\
\hline Non-predatory cladocerans & 0.09 & 0.005 & & 0.03 & 0.04 \\
\hline Copepods & 0.042 & 0.0005 & & 0.01 & 0.04 \\
\hline Mysids & 0.0003 & 0.0001 & & 0.0001 & 0.001 \\
\hline \multicolumn{6}{|l|}{ Periphyton: } \\
\hline Epiphytic bacteria and fungi & & 0.002 & 0.001 & 0.005 & 0.005 \\
\hline Protozooperiphyton & 0.001 & 0.001 & & 0.006 & 0.008 \\
\hline Mesozooperiphyton & 0.0085 & 0.002 & & 0.005 & 0.005 \\
\hline Sessile macrozooperiphyton & 0.0005 & 0.0005 & & 0.0005 & 0.003 \\
\hline Motile macrozooperiphyton & 0.0035 & 0.0005 & & & \\
\hline \multicolumn{6}{|l|}{ Benthos: } \\
\hline Chironomus sp. larvae & 0.017 & 0.001 & & & \\
\hline Dreissena polymorpha & 0.024 & 0.01 & & 0.01 & 0.06 \\
\hline Other molluscs & 0.0016 & 0.0007 & & 0.0016 & 0.005 \\
\hline \multicolumn{6}{|l|}{ Ichthyofauna: } \\
\hline Larvae and fry of planktivorous fish & 0.00001 & & & & \\
\hline Larvae and fry of benthivorous fish & 0.0001 & & & & \\
\hline Larvae and fry of piscivorous fish & 0.00003 & & & & \\
\hline Natural mortality & 0.05 & & & & \\
\hline Export & 0.077 & 0.073 & 0.779 & 0.048 & 0.031 \\
\hline Sedimentation & 0.194 & 0.653 & & 0.429 & 0.275 \\
\hline
\end{tabular}


phytoplankton production was sedimented on the bottom, about $8 \%$ being exported to the Pomeranian Bay.

The efficiency of allochthonous organic matter utilisation in the Great Lagoon pelagic compartment was low. The major consumer utilising about $20 \%$ of the organic matter supply was the bacterioplankton. Zooplankton and -benthos utilised as little as few per cent of the allochthonous POM supplied. About $65 \%$ of the total POM supply were sedimented, whereas almost $80 \%$ of the allochthonous DOM supplied were exported to the Pomeranian Bay.

Consumers in the ecosystem relied more on faeces and remains of organisms produced in the water column than they did on the allochthonous organic matter, as the bacterio- and zooplankton as well as bivalves together used up more than half of the amount produced. The non-utilised detritus was sedimented, some small amounts being exported from the system.

The bacterioplankton was the most important pelagic consumer of non-living organic matter and was, in turn, consumed primarily by protists responsible for using up half of the bacterial production (Table 2.7). A high proportion (about $30 \%$ ) of the bacterioplankton production was also used up by the metazoan zooplankton, mainly cladocerans.

In the zooplankton, the trophic link matrix was somewhat complicated by within-group utilisation (feeding on representatives of the same trophic group). This phenomenon is particularly pronounced in protists when they are treated as a single food web component. It was assumed in the model, that protists feeding on other protists utilised $30 \%$ of the protist production based on consumption of other food web components. Representatives of the metazoan zooplankton were the most important consumers of the net protozooplankton production (i.e., the sum total of production of all protists minus consumption of protists feeding on other protists); taken together, they utilised about $85 \%$ of that production. Only a slight proportion of the protist production (less than $4 \%$ ) was exported, the fast growth rate of protists compensating for most losses due to export.

The production of rotifers, the finest fraction of the metazoan zooplankton, was primarily (more than 40\%) utilised by the larger zooplankters: copepods and the predatory cladoceran Leptodora kindti. Fish, primarily larvae and fry, utilised about $25 \%$ of the rotifer production, a few per cent each being available to the sessile zooperiphyton (Cordylophora) and the zebra mussel. Productions of non-predatory cladocerans and copepods were utilised to a similar degree. The predatory cladoceran L. kindti removed from several to $20 \%$, the highest proportion (about 50\%) being used up by fish. They utilised also almost the entire available production of $L$. kindti and mysids. Export of the metazoan zooplankton production was estimated from 10 to almost 30\%, whereas export of mysids was considered non-existent because, as already mentioned, they are capable of resisting the outflowing current and may even enter the Great 
Table 2.7 Utilisation of bacterio- and zooplankton production. Values in italics indicate the withingroup utilisation. Values in each column (without within-group utilisation) add up to 1 .

\begin{tabular}{|c|c|c|c|c|c|c|c|}
\hline 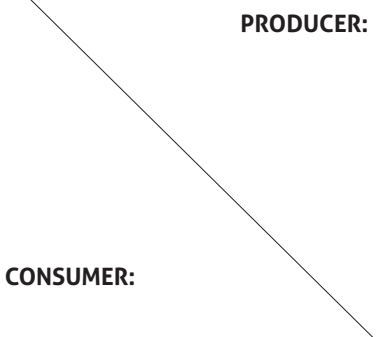 & 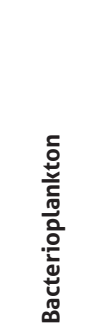 & 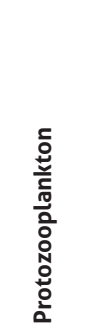 & 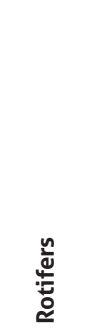 & 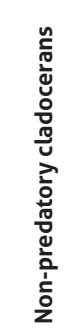 & 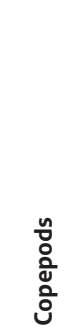 & 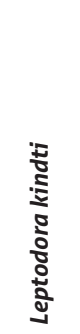 & 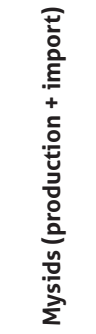 \\
\hline \multicolumn{8}{|l|}{ Plankton: } \\
\hline Protozooplankton & 0.5 & 0.3 & & & & & \\
\hline Rotifers & 0.06 & 0.3 & 0.05 & & & & \\
\hline Non-predatory cladocerans & 0.22 & 0.357 & & & & & \\
\hline Copepods & 0.02 & 0.2 & 0.2 & 0.06 & 0.04 & & \\
\hline Leptodora kindti & & & 0.21 & 0.203 & 0.14 & & \\
\hline Mysids & & & 0.015 & 0.005 & 0.005 & 0.015 & \\
\hline \multicolumn{8}{|l|}{ Periphyton: } \\
\hline Protozooperiphyton & 0.0025 & & & & & & \\
\hline Mesozooperiphyton & 0.002 & & & & & & \\
\hline Sessile macrozooperiphyton & 0.001 & 0.01 & 0.04 & 0.015 & 0.015 & & \\
\hline \multicolumn{8}{|l|}{ Benthos: } \\
\hline Dreissena polymorpha & 0.025 & 0.035 & 0.05 & 0.01 & 0.01 & & \\
\hline Other molluscs & 0.0016 & 0.0016 & 0.0016 & & & & \\
\hline \multicolumn{8}{|l|}{ Ichthyofauna: } \\
\hline Larvae and fry of planktivorous fish & & & 0.065 & 0.05 & 0.025 & 0.03 & 0.01 \\
\hline Juvenile and adult planktivorous fish & & & 0.03 & 0.03 & 0.021 & 0.07 & 0.53 \\
\hline Larvae and fry of benthivorous fish & & & 0.107 & 0.23 & 0.3 & 0.11 & 0.01 \\
\hline Juvenile and adult benthivorous fish & & & & 0.05 & 0.05 & 0.46 & 0.08 \\
\hline Larvae and fry of piscivorous fish & & & 0.047 & 0.1 & 0.076 & 0.05 & 0.23 \\
\hline Juvenile and adult piscivorous fish & & & & 0.018 & 0.018 & 0.02 & 0.08 \\
\hline \multicolumn{8}{|l|}{ Birds: } \\
\hline Herbivorous birds & & & & & & & 0.011 \\
\hline Molluscivorous birds & & & & & & & 0.0045 \\
\hline Omnivorous birds & & & & & & & 0.00077 \\
\hline Natural mortality & 0.05 & 0.06 & 0.14 & 0.123 & 0.052 & 0.05 & 0.044 \\
\hline Export & 0.115 & 0.038 & 0.098 & 0.106 & 0.288 & 0.192 & 0 \\
\hline
\end{tabular}


Lagoon from the Pomeranian Bay. This active migration of mysids to the Lagoon was factored in into the model as their additional supply, in addition to the autochthonous production.

To summarise utilisation of the production and organic matter supply in the pelagic compartment of the ecosystem, it has to be emphasised that the largest part (65-95\%) of the production of live components is utilised as food by other ecosystem components (Fig. 2.2). The autochthonous non-living organic matter was a less important food source, but more than $50 \%$ of its supply was consumed in the water column. The allochthonous organic matter was utilised the least. Most of the allochthonous DOM was exported, unused, to the Pomeranian Bay, whereas most of the allochthonous POM sedimented onto the bottom. In addition, an estimated $30-40 \%$ of autochthonous organic matter and about $20 \%$ of the phytoplankton production sedimented out. From a few to almost $30 \%$ of the planktonic production was exported to the Pomeranian Bay.

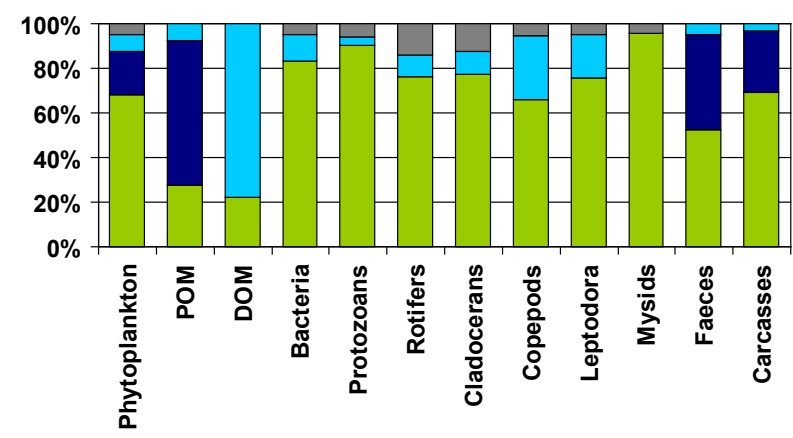

$\square$ predation mortality / consumption $\square$ sedimentation $\square$ export $\square$ natural mortality

Figure 2.2 Utilisation of production of planktonic organisms and non-living organic matter in the pelagic compartment of the ecosystem.

\subsubsection{Utilisation of Periphyton Production}

Trophic relationships in the Great Lagoon periphyton belong to those known the least, therefore the periphyton components' production utilisation coefficients (Table 2.8) are mostly based on the authors' intuitions or are guess estimates. It was assumed that the phytoperiphyton production was utilised primarily by the periphytic bacteria and fungi (about 40\%), protists (about 20\%), and meso- and macrozooperiphyton (about 35\% taken together). In addition to the periphyton, also littoral invertebrates could utilize some (about $5 \%$ ) of the 
Table 2.8 Utilisation of periphytic production. Values in italics indicate the within-group utilisation. Values in each column (without within-group utilisation) add up to 1.

\begin{tabular}{|c|c|c|c|c|c|c|}
\hline$x$ & 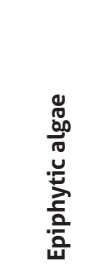 & 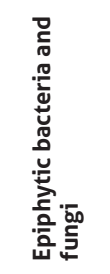 & 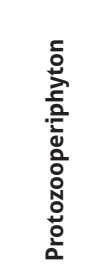 & 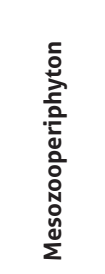 & 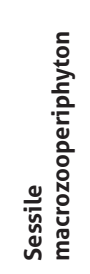 & 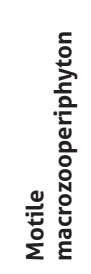 \\
\hline \multicolumn{7}{|l|}{ Plankton: } \\
\hline Mysids & 0.001 & 0.001 & 0.001 & 0.001 & & \\
\hline \multicolumn{7}{|l|}{ Periphyton: } \\
\hline Epiphytic bacteria and fungi & 0.37 & & & & & \\
\hline Protozooperiphyton & 0.18 & 0.65 & 0.15 & & & \\
\hline Mesozooperiphyton & 0.26 & 0.17 & 0.88 & 0.1 & & \\
\hline Sessile macrozooperiphyton & 0.005 & 0.02 & 0.05 & 0.4 & & 0.25 \\
\hline Motile macrozooperiphyton & 0.09 & 0.1 & 0.02 & 0.55 & 0.4 & 0.25 \\
\hline \multicolumn{7}{|l|}{ Benthos: } \\
\hline Other molluscs & 0.002 & 0.001 & 0.001 & 0.001 & 0.001 & \\
\hline Remaining zoobenthos & 0.048 & 0.02 & 0.01 & 0.01 & 0.002 & 0.001 \\
\hline \multicolumn{7}{|l|}{ Ichthyofauna: } \\
\hline Larvae and fry of planktivorous fish & 0.0001 & 0.0002 & 0.0005 & 0.001 & 0.005 & 0.006 \\
\hline Juvenile and adult planktivorous fish & 0.0001 & 0.0001 & 0.0001 & 0.0001 & & 0.0001 \\
\hline Larvae and fry of benthivorous fish & 0.005 & 0.001 & 0.001 & 0.001 & 0.025 & 0.08 \\
\hline Juvenile and adult benthivorous fish & 0.0005 & 0.0005 & 0.0005 & 0.00015 & 0.03 & 0.48 \\
\hline Larvae and fry of piscivorous fish & & & & & 0.005 & 0.025 \\
\hline Juvenile and adult piscivorous fish & & & & & & 0.06 \\
\hline \multicolumn{7}{|l|}{ Birds: } \\
\hline Herbivorous birds & 0.0002 & 0.0002 & 0.0002 & 0.0002 & 0.001 & 0.0015 \\
\hline Molluscivorous birds & 0.00005 & 0.00005 & 0.00005 & 0.00005 & 0.0003 & 0.0002 \\
\hline Emergence & & & & & & 0.04 \\
\hline Natural mortality & 0.04 & 0.04 & 0.04 & 0.04 & 0.53 & 0.06 \\
\hline
\end{tabular}


epiphytic algal production. The periphytic bacteria and fungi were assumed to be consumed primarily (65\% of production) by periphytic protists, almost the entire remainder being used by the zooperiphyton. The mesozooperiphyton was assigned, in the model, a role of the major periphytic protist consumer (consumption of about $90 \%$ of the net production) assisted, to some extent, by the macrozooperiphyton. The within-group protist consumption was included in the model as well. The internal cycling played a role in the mesozooperiphyton, too, the macrozooperiphyton being considered the major consumer of its net production. The sessile macrozooperiphyton production was assumed to be consumed primarily by the motile macrozooperiphyton (40\%, mainly gammarid predation on Cordylophora), but about $5 \%$ of the production could be also used by fish (mainly those feeding on the juvenile zebra mussel). The fish were also considered the most important consumer of the motile macrozooperiphyton (about $2 / 3$ of the net production). In the motile macrozooperiphyton, of importance was probably the within-group predation. The motile macrozooperiphyton consisted of, i.a., insect larvae. Emergence of the adult insects and the associated energy losses could amount to about few per cent of production of this component.

With the assumptions as above, more than $90 \%$ of the periphyton production was used as food, the natural mortality amounting to a few percent of production (Fig. 2.3). An exception was the sessile macrozooperiphyton the production of which was much less (about 60\%) utilised; chitinous covers, exoskeletons, shells etc. of those animals protect them from predation and increase the importance of natural mortality.

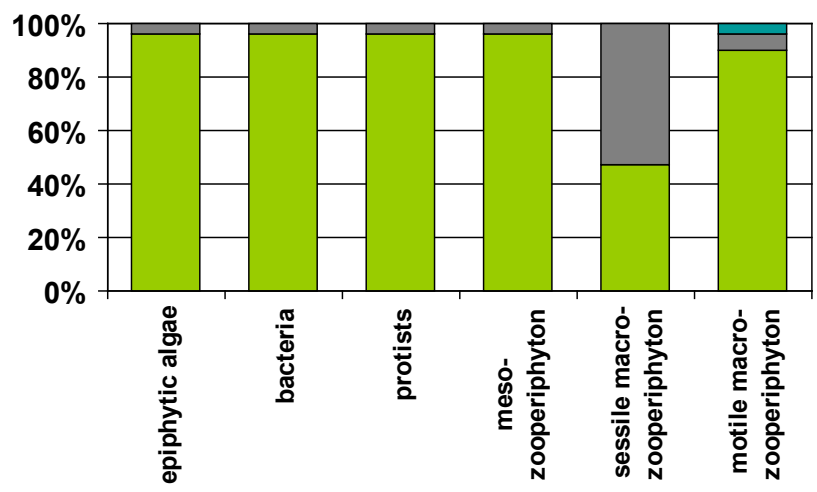

$\square$ predation mortality $\square$ natural mortality $\square$ emergence 


\subsubsection{Utilisation of Benthic Production and Non- living Organic Matter Supply in the Sedimentary Compartment of the Ecosystem}

Based on the general hydrobiological knowledge (Wetzel, 2001), the benthic vegetation of the Great Lagoon was assumed to be, when fresh, poorly utilised by consumers (Table 2.9; Fig. 2.4). No animal was a consumer of the rush (emergent) plants. Production of soft (submerged and floating-leaved) macrophytes was used mostly by littoral and periphytic invertebrates, but their consumption engaged as little as a few per cent of the production. A relatively high utilisation rate was assumed for the microphytobenthos (about $3 / 4$ of the production), the meio- and macrobenthos being deemed the major microalgal grazers.

Almost the entire helophyte production, more than $90 \%$ of the production by soft macrophytes, and about one-quarter of the microphytobenthos production contributed to the phytodetritus pool which served as food mainly for benthic bacteria and fungi and for the meiobenthos. The sedimented phytoplankton, treated in the model as a separate food web component, was most probably consumed by benthic animals more efficiently than the phytobenthos. The major consumers of sedimented phytoplankton were, in addition to bacteria, Chironomus sp. larvae and the meiobenthos. The importance of sedimented phytoplankton in the diet of Chironomus sp. larvae was pointed out by Wolnomiejski et al. (2000). Like in the pelagic ecosystem compartment, the major consumers of non-living organic matter in the sediment were bacteria and fungi. The model assumed that, in addition to plant remains, bacteria and fungi used up $50 \%$ of the sedimented allochthonous matter and $60-70 \%$ of the sedimented faeces and animal remains. Among invertebrates, the meiobenthos was attributed the highest utilisation of the non-living organic matter (Table 2.9). It is likely that animal remains were a form of non-living organic matter consumed most readily by benthic animals.

The non-living organic matter not utilised by consumers is accumulated in bottom sediments. For the purposes of the model, it was assumed that the highest accumulation rate (more than $30 \%$ of the supply to the sediment) was typical of the allochthonous matter, followed by faeces and plant debris (several percent of the supply each). Only a small part (a few per cent) of the sedimented phytoplankton and animal remains eventually were accumulated in the sediment (Fig. 2.4).

Benthic bacteria, fungi and protists were most likely consumed primarily by the meiobenthos. In the model, the meiobenthos was attributed about $70 \%$ utilisation of production of those components (Table 2.10). Of the remaining invertebrates, a larger part in the overall consumption of benthic bacteria, fungi, 
The Szczecin Lagoon Ecosystem:

The Biotic Community of the Great Lagoon and its Food Web Model

Table 2.9 Utilisation of phytobenthos primary production and non-living organic matter supply in the benthic ecosystem compartment. Values in individual columns add up to 1.

\begin{tabular}{|c|c|c|c|c|c|c|c|c|}
\hline $\begin{array}{r}\text { PRODUCER } \\
\text { OR FOOD } \\
\text { SOURCE: }\end{array}$ & 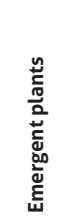 & 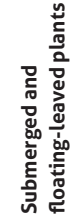 & 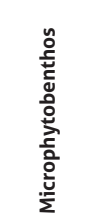 & 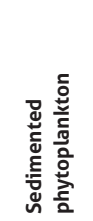 & 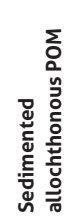 & $\begin{array}{l}\frac{n}{5} \\
\frac{0}{0} \\
\frac{0}{0} \\
\frac{\ddot{c}}{a} \\
\frac{0}{a}\end{array}$ & 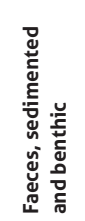 & 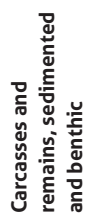 \\
\hline \multicolumn{9}{|l|}{ Plankton: } \\
\hline Mysids & & & 0.01 & 0.005 & 0.0001 & 0.001 & 0.0003 & 0.001 \\
\hline \multicolumn{9}{|l|}{ Periphyton: } \\
\hline $\begin{array}{l}\text { Epiphytic bacteria and } \\
\text { fungi }\end{array}$ & 0.005 & 0.005 & & & & 0.05 & 0.001 & 0.0001 \\
\hline Mesozooperiphyton & & & & & & 0.02 & & \\
\hline $\begin{array}{l}\text { Motile } \\
\text { macrozooperiphyton }\end{array}$ & & 0.02 & 0.0025 & & & 0.0066 & & \\
\hline \multicolumn{9}{|l|}{ Benthos: } \\
\hline $\begin{array}{l}\text { Benthic bacteria and } \\
\text { fungi }\end{array}$ & & & 0.01 & 0.3 & 0.5 & 0.6 & 0.7 & 0.68 \\
\hline Benthic protists & & & 0.025 & 0.05 & 0.03 & 0.01 & 0.01 & 0.05 \\
\hline Meiofauna & & & 0.36 & 0.2 & 0.1 & 0.1 & 0.09 & 0.1 \\
\hline Chironomus sp. larvae & & & 0.1 & 0.34 & 0.02 & 0.015 & 0.0082 & 0.005 \\
\hline $\begin{array}{l}\text { Macrobenthic } \\
\text { ostracods }\end{array}$ & & & 0.042 & 0.005 & 0.001 & 0.002 & 0.0035 & 0.01 \\
\hline Oligochaetes & & & 0.075 & 0.02 & 0.03 & 0.01 & 0.019 & 0.02 \\
\hline Dreissena polymorpha & & & & 0.04 & 0.002 & & & \\
\hline Other molluscs & & & 0.022 & 0.0033 & 0.0007 & 0.0015 & 0.0012 & 0.0015 \\
\hline Remaining zoobenthos & & 0.02 & 0.1 & 0.008 & 0.005 & 0.02 & 0.001 & 0.05 \\
\hline \multicolumn{9}{|l|}{ Ichthyofauna: } \\
\hline $\begin{array}{l}\text { Larvae and fry of } \\
\text { planktivorous fish }\end{array}$ & & 0.0002 & 0.00005 & 0.00005 & & & & \\
\hline $\begin{array}{l}\text { Juvenile and adult } \\
\text { planktivorous fish }\end{array}$ & & 0.0005 & 0.00005 & 0.00001 & & & & \\
\hline $\begin{array}{l}\text { Larvae and fry of } \\
\text { benthivorous fish }\end{array}$ & & 0.01 & 0.004 & 0.00001 & & & & 0.001 \\
\hline $\begin{array}{l}\text { Juvenile and adult } \\
\text { benthivorous fish }\end{array}$ & & 0.02 & 0.006 & 0.0002 & & 0.001 & & 0.005 \\
\hline $\begin{array}{l}\text { Larvae and fry of } \\
\text { piscivorous fish }\end{array}$ & & & & 0.0001 & & & & \\
\hline $\begin{array}{l}\text { Juvenile and adult } \\
\text { piscivorous fish }\end{array}$ & & & & & & & & 0.0001 \\
\hline \multicolumn{9}{|l|}{ Birds: } \\
\hline Herbivorous birds & & 0.0105 & & & & 0.0002 & & \\
\hline Molluscivorous birds & & 0.0011 & & & & 0.00005 & & \\
\hline Natural mortality & 0.995 & 0.91 & 0.24 & & & & & \\
\hline $\begin{array}{l}\text { Deposition in bottom } \\
\text { sediments }\end{array}$ & & & & 0.028 & 0.311 & 0.163 & 0.166 & 0.076 \\
\hline
\end{tabular}




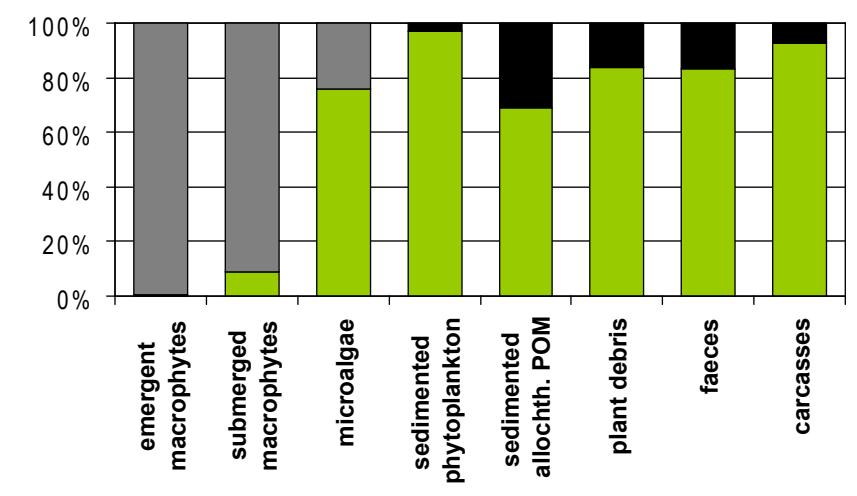

$\square$ predation mortality / consumption $\square$ natural mortality $\square$ accumulation

Figure. 2.4 Utilisation of benthic primary production and non-living organic matter supply in the benthic compartment of the ecosystem.

and protists could be played by the pelophilous taxa: oligochaetes, ostracods, and chironomid larvae. Pelophilous macroinvertebrates were most likely also the major consumers of the meiobenthos. The model assumed Chironomus sp., macrobenthic ostracods, and oligochaetes to jointly utilise about $50 \%$ of the meiofaunal production. About $10 \%$ of the meiobenthic production could be used up by littoral invertebrates, a few per cent each - by the zooplankton (mainly Leptodora) and benthivorous fish.

As opposed to the ecological categories discussed so far, for which estimates of production utilisation stemmed mainly from literature and theoretical knowledge, utilisation of production by macrobenthic components could be estimated, to a large extent, on results of fish feeding studies, carried out in the Great Lagoon (Wolnomiejski and Grygiel, 1994b; 1994C; 2002). Production of the macrobenthic invertebrates was utilised primarily by benthivorous fish. They were assumed to consume an estimated $85-90 \%$ of the production of Chironomus sp. larvae and macrobenthic ostracods. Fish were most probably the main predators on the zebra mussel, other molluscs, and the remaining littoral zoobenthos, and consumed $15-50 \%$ of their production. Studies on food composition of fish in the Great Lagoon failed to show any substantial contribution of oligochaetes to the fish diet. It was therefore assumed that oligochaetes fell prey primarily to other invertebrates; assuming the oligochaete contribution to the fish food not exceeding $2 \%$, fish would consume less than $20 \%$ of the oligochaete production. In addition to benthivorous fish, an important role in consumption of certain macrobenthic components could be played by predatory fish. They (perch, eel) were assumed to consume several percent each 
The Szczecin Lagoon Ecosystem:

The Biotic Community of the Great Lagoon and its Food Web Model

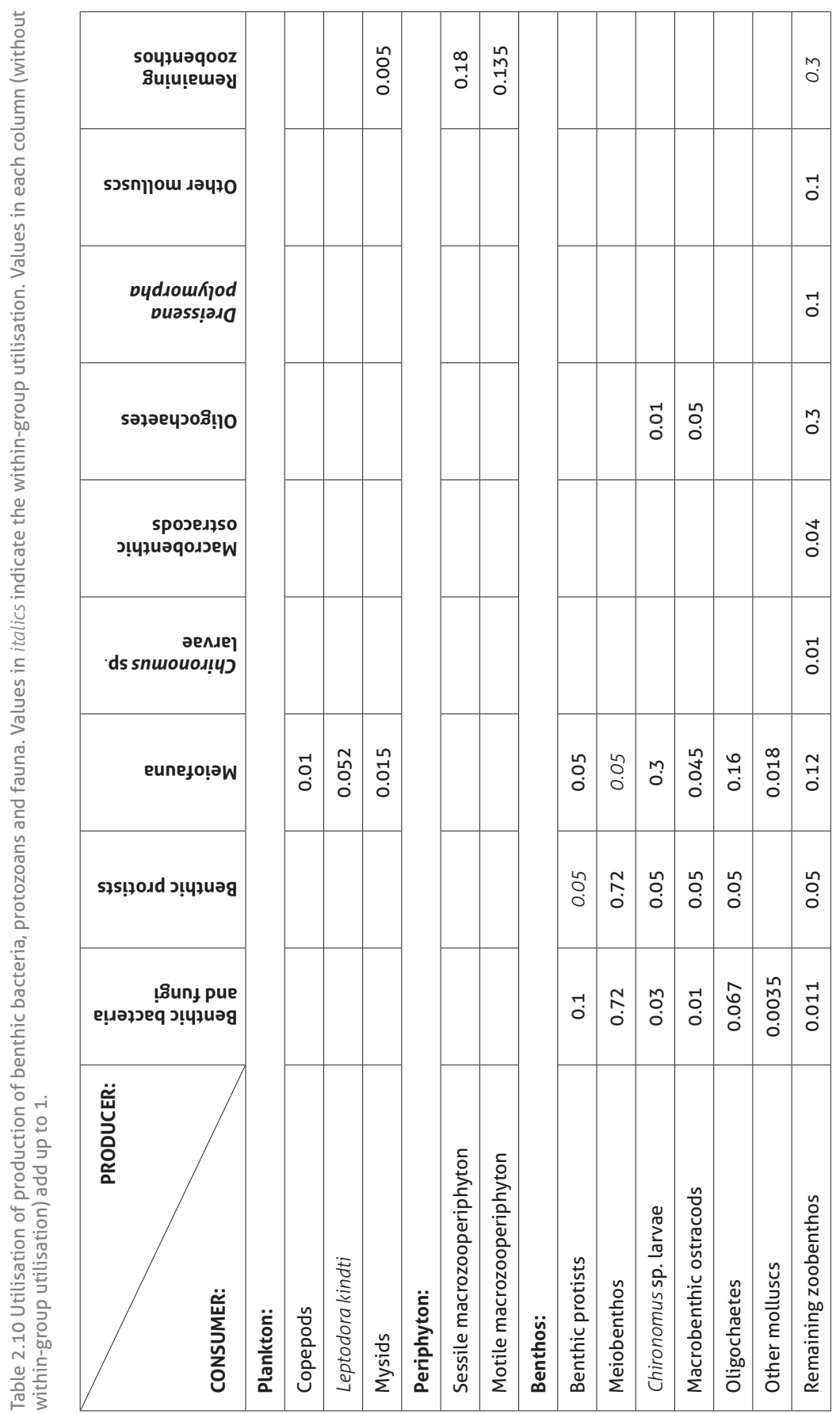




\begin{tabular}{|c|c|c|c|c|c|c|c|c|c|c|c|}
\hline $\begin{array}{l}\text { soyzuəqooz } \\
\text { 8u!̣u!̣məy }\end{array}$ & & $\stackrel{\sim}{o}$ & 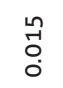 & $\begin{array}{l}\infty \\
0 \\
0\end{array}$ & ma & $\begin{array}{l}\tilde{n} \\
\tilde{O} \\
0 \\
0\end{array}$ & $\tilde{m}$ & & 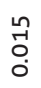 & $\stackrel{0}{\circ}$ & नें \\
\hline sЈsnן|l גәчғо & & $\begin{array}{l}\stackrel{-}{0} \\
\dot{0}\end{array}$ & $\begin{array}{l}\hat{\circ} \\
\stackrel{0}{0}\end{array}$ & $\begin{array}{l}7 \\
0 \\
0\end{array}$ & ษั่ & $\begin{array}{l}\hat{0} \\
0 \\
0 \\
\dot{0}\end{array}$ & & & $\begin{array}{l}\underset{N}{\tilde{O}} \\
\stackrel{0}{0}\end{array}$ & & ले \\
\hline $\begin{array}{r}\text { pydiownilod } \\
\text { Duass!ada }\end{array}$ & & $\begin{array}{l}\pi \\
0 \\
0 \\
0\end{array}$ & $\begin{array}{l}\text { o̊ } \\
\text { o. }\end{array}$ & $\begin{array}{l}\hat{0} \\
\stackrel{0}{0} \\
0\end{array}$ & $\stackrel{\text { กิ }}{\circ}$ & & $\begin{array}{ll}-1 \\
0 \\
\dot{0}\end{array}$ & & $\tilde{o}$ & & $\underset{0}{N}$ \\
\hline ธәңәечวовి!1ం & & $\begin{array}{l}\ddot{1} \\
0 \\
0\end{array}$ & $\begin{array}{l}\stackrel{M}{o} \\
\stackrel{0}{0}\end{array}$ & $\stackrel{\circ}{\circ}$ & กั่ & $\begin{array}{l}\hat{\circ} \\
\stackrel{0}{0} \\
\dot{0}\end{array}$ & $\stackrel{-1}{0}$ & & & & ֻै \\
\hline 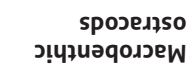 & & $\begin{array}{l}\text { ñ } \\
0 \\
0 \\
0\end{array}$ & o̊ & 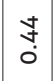 & $\stackrel{\text { Ma }}{0}$ & $\stackrel{1}{\circ}$ & $\begin{array}{l}-1 \\
0 \\
0\end{array}$ & & & & $\begin{array}{l}\text { nم } \\
\text { Oे }\end{array}$ \\
\hline $\begin{array}{r}\text { әелגе] } \\
\text { ds snmouod!ly }\end{array}$ & & 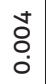 & 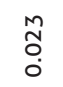 & $\mid \begin{array}{l}1 \\
0 \\
0 \\
0\end{array}$ & $\begin{array}{l}\stackrel{n}{\hat{0}} \\
\stackrel{0}{0}\end{array}$ & $\begin{array}{l}\tilde{\Omega} \\
0 \\
0\end{array}$ & $\begin{array}{l}N \\
\hat{O} \\
0\end{array}$ & & & $\stackrel{\infty}{\infty}$ & $\stackrel{\text { no }}{0}$ \\
\hline eunejo!̣W & & $\begin{array}{l}\tilde{o} \\
\text { ¿ } \\
0\end{array}$ & $\begin{array}{l}\text { n̊ } \\
\stackrel{0}{0} \\
0\end{array}$ & \begin{tabular}{l}
0 \\
\multirow{U}{*}{} \\
0 \\
0
\end{tabular} & $\stackrel{\text { Ln }}{0}$ & & & & & & m. \\
\hline 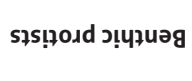 & & & & & 望 & & & & & & ô. \\
\hline 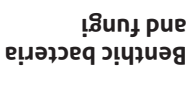 & & & & & $\begin{array}{l}\text { ¿n } \\
\stackrel{0}{0} \\
0\end{array}$ & & & & & & : \\
\hline 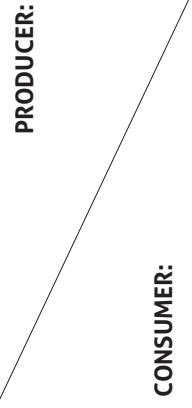 & 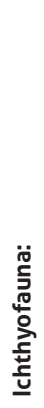 & 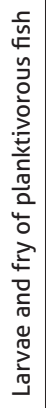 & 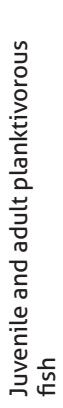 & 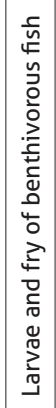 & 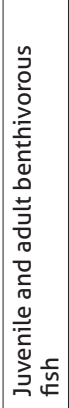 & 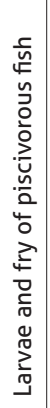 & 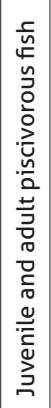 & 苑 & 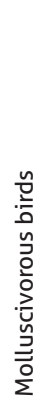 & 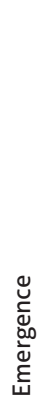 & 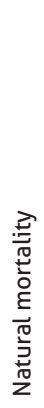 \\
\hline
\end{tabular}


of production of Chironomus sp. larvae and littoral invertebrates other than the zebra mussel. In the case of non-mollusc littoral zoobenthos ('remaining zoobenthos': insects, crustaceans, and leeches), within-group predation could be of importance (estimated at $30 \%$ of production based on consumption of other components). A few per cent of production of molluscs and other littoral invertebrates were consumed by molluscivorous birds.

A part of the aquatic insect larvae production is utilised for metamorphosis and emergence of the imagines. Energy losses associated with emergence of adult insects, metamorphosis, and export of exuvia to the Pomeranian Lagoon were estimated at about $8 \%$ of production of Chironomus sp. and a somewhat lower percent of production of the remaining (mainly littoral) zoobenthos and motile macrozooperiphyton (Tables 2.8 and 2.10), a substantial contribution to which is provided by insect larvae.

Natural mortality of some benthic components (bacteria, protists, Chironomus sp. larvae, ostracods) was estimated at a low level of a few percent of production. However, natural mortality of molluscs, particularly D. polymorpha, and oligochaetes, was estimated to be high, at $35-70 \%$ of their production. This high natural mortality is most likely related to poor availability of those animals to consumers. Natural mortality of the meiobenthos and the remaining, primarily littoral, zoobenthos, assumed intermediate values at a level of several percent of production (Fig. 2.5).

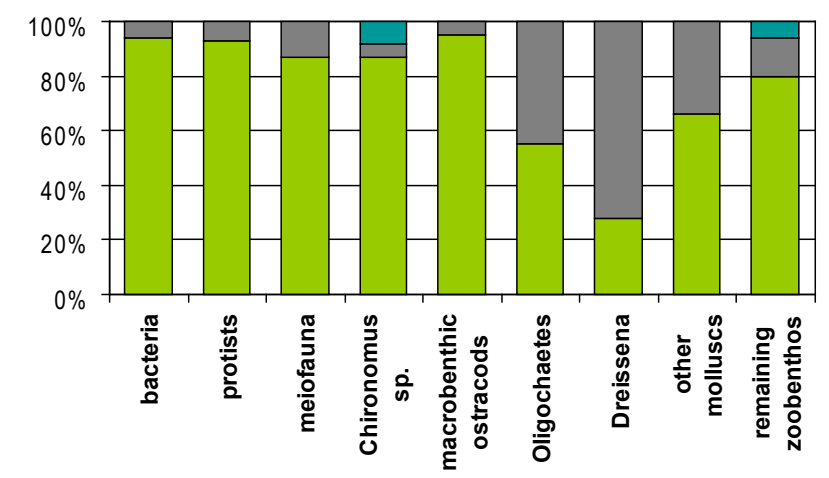

$\square$ predation mortality $\square$ natural mortality $\square$ emergence 


\subsubsection{Utilisation of Fish Production}

Production of larvae and fry of planktivorous, benthivorous, and predatory fish was utilised in a similar manner. The largest part of larval and fry production (about 60-70\%) was consumed by juvenile and adult predatory fish. Predation pressure of planktivorous fish was estimated at a few per cent of larvae and fry production; the main prey of planktivorous fish (primarily smelt) was the ichthyoplankton. Predation on larvae and fry by piscivorous birds was estimated at a few per cent of production as well, but the major prey was the fry. About $10 \%$ of production of fish larvae and fry constituted recruitment to that part of the population consisting of juveniles and adult fish. Natural mortality of fish larvae and fry was at a level of as little as a few per cent (Table 2.11).

Production of older plankti- and benthivorous fish was utilised in a similar manner. Those fish groups were mainly preyed upon by predatory species

Table 2.11 Utilisation of fish production. Values in italics indicate the within-group utilisation. Values in each column (without within-group utilisation) add up to 1.

\begin{tabular}{|c|c|c|c|c|c|c|}
\hline CONSUMER: & 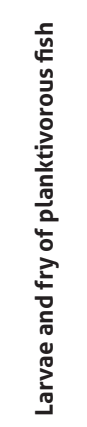 & 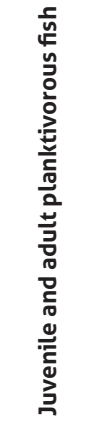 & 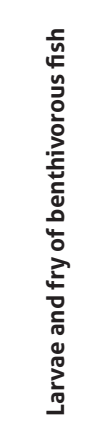 & 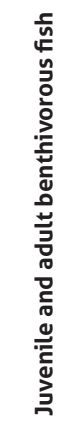 & 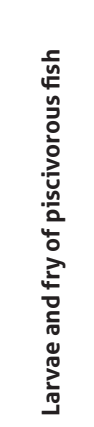 & 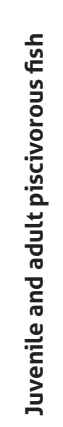 \\
\hline \multicolumn{7}{|l|}{ Ichthyofauna: } \\
\hline Juvenile and adult planktivorous fish & 0.05 & & 0.05 & & 0.05 & \\
\hline \multicolumn{7}{|l|}{ Juvenile and adult benthivorous fish } \\
\hline Larvae and fry of piscivorous fish & 0.13 & & 0.15 & & 0.08 & \\
\hline Juvenile and adult piscivorous fish & 0.594 & 0.682 & 0.585 & 0.622 & 0.7 & 0.2 \\
\hline \multicolumn{7}{|l|}{ Birds: } \\
\hline Omnivorous birds & 0.0005 & & 0.00078 & & 0.0003 & \\
\hline Piscivorous birds & 0.09 & 0.07 & 0.061 & 0.04 & 0.06 & \\
\hline Recruitment & 0.1 & & 0.1 & & 0.1 & \\
\hline Natural mortality & 0.04 & 0.17 & 0.05 & 0.16 & 0.09 & 0.68 \\
\hline Fishing mortality & & 0.0785 & & 0.18 & & 0.32 \\
\hline
\end{tabular}


(60-70\% of production) and by piscivorous birds (a few per cent of production). Fishing mortality in planktivorous and benthivorous fish was less than $10 \%$ and less than $20 \%$ of their production, respectively. Natural mortality of planktiand benthivorous fish was estimated at dozen or so per cent. In the case of predatory fish, within-group predation could be important; it was estimated at $20 \%$ of production of those fish feeding on other food web components. Fishing mortality concerned $32 \%$ of the net production of juvenile and adult predatory species, the remaining types of mortality affecting as much as $68 \%$ of the production.

With respect to juvenile and adult fish, natural mortality shown in Table 2.11 includes also the reproductive material deposited during spawning in the environment. Although fish spawning is usually seen as production of new biomass, actually the newly hatched larvae account only for a small fraction of the reproductive material deposited; a much larger part of that material dies off during embryonic development or becomes food for other animals (Szczerbowski, 1993). In the juvenile and adult fish taken together, production of the reproductive materials accounts for about $10 \%$ of the total production of those fish (Section 1.12.5.6). In the present model, natural mortality of planktiand benthivorous fish due to diseases, damages, senility, etc. concerns a few percent of production of juveniles and adults. In the case of predatory fish, natural mortality due to such causes would concern as much as over $50 \%$ of their production (Fig. 2.6). Such a high natural mortality of predatory fish does not seem plausible. The discrepancy would point out to real catches much exceeding the reported landings.

With regard to the waterfowl, their entire production was assumed to be exported from the system.

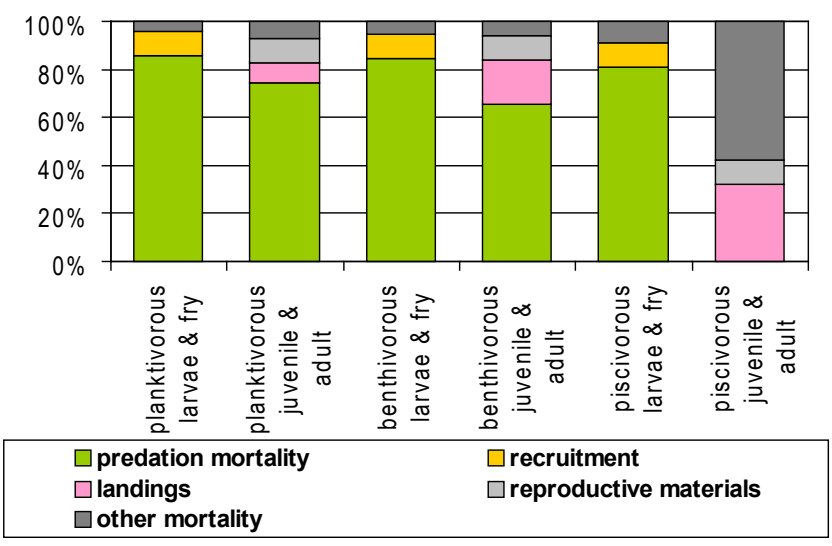

Figure 2.6 Utilisation of fish production. Within-group predation not shown. 


\subsubsection{Energy Flow Budget in the Great Lagoon Ecosystem}

Basic elements of the energy budget of all the food web components in the Great Lagoon, produced by the model, are shown in Table 2.12. Additionally, the table contains the empirical biomass data and the P/B values adopted in this study. It can be seen that in some cases, the production estimated by the model deviates strongly from that produced by the biomass multiplied by P/B (cf. Table 2.3). The discrepancies are due to within-group consumption discussed earlier, which concerns certain food web components. Due to this effect, net production of a component available as food to other components is lower than the algebraic sum of production of all the individuals making up the component. Similarly, consumption of those components affected by within-group consumption, given in Table 2.12, is lower than the algebraic sum of consumption of all the individuals making up the component, as it concerns only the uptake of food derived from other food web components.

The model allowed to determine production of those components, for which biomass and production rate data were missing. The most important food web components, characterized only with the aid of the model, include benthic bacteria and fungi; according to the model, their production was by several per cent higher than that of the bacterioplankton. On the other hand, production of the benthic protists turned out to be almost 6 times lower than production of the pelagic protists.

When comparing biomasses of individual food web components, it is evident (Fig. 2.7) that the highest biomass in the Great Lagoon was that of vascular plants, primarily the emergent vegetation (mainly reed). Macrophyte biomass was several times higher than that of the phytoplankton, and accounted for almost $80 \%$ of the total biomass of the Great Lagoon flora and fauna combined (but without the biomass of bacteria and protists). The highest contribution to the animal biomass was provided by the zebra mussel (about $1 / 4$ of the animal biomass). The total zoobenthos accounted for almost $60 \%$ of the faunal biomass; fish, zooplankton, zooperiphyton, and waterfowl contributed 27, 8, 5, and $0.1 \%$, respectively. Among the fish, the highest biomass was attributed to the benthivorous species. The biomass of larvae and fry accounted for as little as $7 \%$ of all the fish biomass in the ecosystem. Compared to the zoobenthos and ichthyofauna, biomass of the zooplankton was low, 7 times lower than the biomass of the zoobenthos and 3 times lower than that of fish. Thus, a larger part of the plant and animal biomass in the Great Lagoon was confined to the bottom, primarily to the littoral zone.

The energy flow in the Great Lagoon was controlled by unicellular organisms. Among autotrophs, the dominant role was played by the phytoplankton (74\% of net primary production), bacteria and fungi being of major importance in the heterotrophic part of the biota. Bacterial and fungal consumption, secondary 
The Szczecin Lagoon Ecosystem:

The Biotic Community of the Great Lagoon and its Food Web Model

Table 2.12 Biomass and energy budgets of the Great Lagoon food web components. $B$, average biomass (empirical data); $P / B$, production to biomass ratio; $C$, consumption; $P$, production (net); $R$, respiration;

FU, faeces and exuvia. C, P, R, and FU are estimates produced by the model.

\begin{tabular}{|c|c|c|c|c|c|c|}
\hline & B & P/B & C & $\mathbf{P}$ & $\mathbf{R}$ & FU \\
\hline & $\mathrm{gC} \mathrm{m}^{-2}$ & season $^{-1}$ & \multicolumn{4}{|c|}{$\mathrm{gC} \mathrm{m}^{-2} \mathrm{yr}^{-1}$} \\
\hline \multicolumn{7}{|l|}{ Plankton: } \\
\hline $\begin{array}{l}\text { Allochthonous } \\
\text { organic matter, POM }\end{array}$ & & & & 100.0 & & \\
\hline $\begin{array}{l}\text { Allochthonous } \\
\text { organic matter, DOM }\end{array}$ & & & & 370.0 & & \\
\hline Phytoplankton & & & & 400.0 & 100.0 & \\
\hline Bacterioplankton & & & 243.5 & 80.4 & 163.2 & \\
\hline Protozooplankton & & & 153.3 & 36.3 & 50.1 & 66.9 \\
\hline Rotifers & 0.10 & 60 & 32.6 & 5.6 & 13.8 & 13.2 \\
\hline $\begin{array}{l}\text { Non-predatory } \\
\text { cladocerans }\end{array}$ & 0.48 & 26.9 & 72.0 & 13.0 & 30.2 & 28.8 \\
\hline Copepods & 0.55 & 10 & 30.2 & 5.3 & 12.8 & 12.2 \\
\hline Leptodora kindti & 0.085 & 15 & 5.4 & 1.3 & 3.0 & 1.1 \\
\hline Mysids $^{a}$ & 0.034 & 3.3 & 1.5 & 0.3 & 0.8 & 0.5 \\
\hline Faeces, pelagic & & & & 122.5 & & \\
\hline $\begin{array}{l}\text { Carcasses and } \\
\text { remains, pelagic }\end{array}$ & & & & 29.1 & & \\
\hline \multicolumn{7}{|l|}{ Periphyton: } \\
\hline Epiphytic algae & 1.570 & 14 & & 22.0 & 5.5 & \\
\hline $\begin{array}{l}\text { Epiphytic bacteria } \\
\text { and fungi }\end{array}$ & & & 14.6 & 4.6 & 9.8 & \\
\hline Protozooperiphyton & & & 8.8 & 2.4 & 2.7 & 3.7 \\
\hline Mesozooperiphyton & 0.089 & 31 & 14.9 & 2.5 & 6.4 & 6.1 \\
\hline $\begin{array}{l}\text { Sessile } \\
\text { macrozooperiphyton }\end{array}$ & 0.400 & 2 & 3.3 & 0.8 & 1.9 & 0.7 \\
\hline $\begin{array}{l}\text { Motile } \\
\text { macrozooperiphyton }\end{array}$ & 0.324 & 5.3 & 6.9 & 1.0 & 3.0 & 2.9 \\
\hline \multicolumn{7}{|l|}{ Benthos: } \\
\hline $\begin{array}{l}\text { Sedimenting } \\
\text { allochthonous POM }\end{array}$ & & & & 65.3 & & \\
\hline $\begin{array}{l}\text { Sedimenting } \\
\text { phytoplankton }\end{array}$ & & & & 77.8 & & \\
\hline $\begin{array}{l}\text { Sedimenting pelagic } \\
\text { faeces }\end{array}$ & & & & 52.6 & & \\
\hline $\begin{array}{l}\text { Sedimenting pelagic } \\
\text { carcasses and remains }\end{array}$ & & & & 8.0 & & \\
\hline Emergent plants & 90.6 & 0.79 & & 71.7 & $3.8^{b}$ & \\
\hline $\begin{array}{l}\text { Submerged and } \\
\text { floating-leaved plants }\end{array}$ & 13.9 & 0.84 & & 11.6 & 2.9 & \\
\hline Microphytobenthos & 2.1 & 15 & & 32.0 & 8.0 & \\
\hline $\begin{array}{l}\text { Benthic bacteria and } \\
\text { fungi }\end{array}$ & & & 277.8 & 91.7 & 186.1 & \\
\hline Benthic protists & & & 20.8 & 6.0 & 6.3 & 8.4 \\
\hline
\end{tabular}


Table 2.12 Biomass and energy budgets of the Great Lagoon food web components. B, average biomass (empirical data); $P / B$, production to biomass ratio; $C$, consumption; $P$, production (net); $R$, respiration; FU, faeces and exuvia. C, P, R, and FU are estimates produced by the model.

\begin{tabular}{|c|c|c|c|c|c|c|}
\hline & B & P/B & C & $\mathbf{P}$ & $\mathbf{R}$ & FU \\
\hline & $\mathrm{gC} \mathrm{m}^{-2}$ & season $^{-1}$ & \multicolumn{4}{|c|}{$\mathrm{gC} \mathrm{m}^{-2} \mathrm{yr}^{-1}$} \\
\hline Meiobenthos & 2.04 & 8 & 134.8 & 15.5 & 38.0 & 81.3 \\
\hline Chironomus sp. larvae & 1.46 & 8 & 48.8 & 11.7 & 17.6 & 19.4 \\
\hline $\begin{array}{l}\text { Macrobenthic } \\
\text { ostracods }\end{array}$ & 0.22 & 2.7 & 5.0 & 0.6 & 1.4 & 3.0 \\
\hline Oligochaetes & 0.49 & 5 & 20.3 & 2.4 & 5.7 & 12.2 \\
\hline Dreissena polymorpha & 3.70 & 1 & 20.6 & 3.7 & 8.6 & 8.2 \\
\hline Other molluscs & 0.54 & 1.11 & 3.3 & 0.6 & 1.4 & 1.3 \\
\hline $\begin{array}{l}\text { Remaining } \\
\text { zoobenthos }\end{array}$ & 0.56 & 6.05 & 13.2 & 2.4 & 5.1 & 5.7 \\
\hline Plant debris & & & & 90.6 & & \\
\hline Faeces $^{c}$ & & & & 217.0 & & \\
\hline $\begin{array}{l}\text { Carcasses and } \\
\text { remains }^{d}\end{array}$ & & & & 22.4 & & \\
\hline \multicolumn{7}{|l|}{ Ichthyofauna: } \\
\hline $\begin{array}{l}\text { Larvae and fry of } \\
\text { planktivorous fish }\end{array}$ & 0.034 & 5 & 1.36 & 0.17 & 0.51 & 0.68 \\
\hline $\begin{array}{l}\text { Juvenile and adult } \\
\text { planktivorous fish }\end{array}$ & 0.440 & 0.733 & 1.89 & 0.32 & 1.21 & 0.38 \\
\hline $\begin{array}{l}\text { Larvae and fry of } \\
\text { benthivorous fish }\end{array}$ & 0.202 & 5 & 8.11 & 1.01 & 3.04 & 4.05 \\
\hline $\begin{array}{l}\text { Juvenile and adult } \\
\text { benthivorous fish }\end{array}$ & 2.600 & 0.733 & 13.61 & 2.01 & 7.62 & 4.08 \\
\hline $\begin{array}{l}\text { Larvae and fry of } \\
\text { piscivorous fish }\end{array}$ & 0.082 & 5 & 3.24 & 0.38 & 1.23 & 1.64 \\
\hline $\begin{array}{l}\text { Juvenile and adult } \\
\text { piscivorous fish }\end{array}$ & 1.055 & 0.6 & 3.40 & 0.55 & 2.54 & 0.35 \\
\hline \multicolumn{7}{|l|}{ Birds: } \\
\hline Herbivorous birds & 0.0022 & & 0.163 & 0.00098 & $0.064^{e}$ & 0.098 \\
\hline Molluscivorous birds & 0.002 & & 0.149 & 0.00090 & $0.059^{e}$ & 0.090 \\
\hline Omnivorous birds & 0.000043 & & 0.002 & 0.000024 & $0.0016^{e}$ & 0.0004 \\
\hline Piscivorous birds & 0.0017 & & 0.202 & 0.00273 & $0.179^{e}$ & 0.020 \\
\hline
\end{tabular}

a in addition to the autochthonous population shown in the table, the model included also the input of mysids from the Pomeranian Bay, estimated at $0.65 \mathrm{gC} \mathrm{m}^{-2} \mathrm{yr}^{-1}$

${ }^{\mathrm{b}}$ respiration attributed to the submerged part of plants

' total: sedimented from the water column as well as derived from periphyton, benthos, fish and birds

d total: sedimented from the water column as well as derived from periphyton, benthos and fish

e outside the aquatic environment 


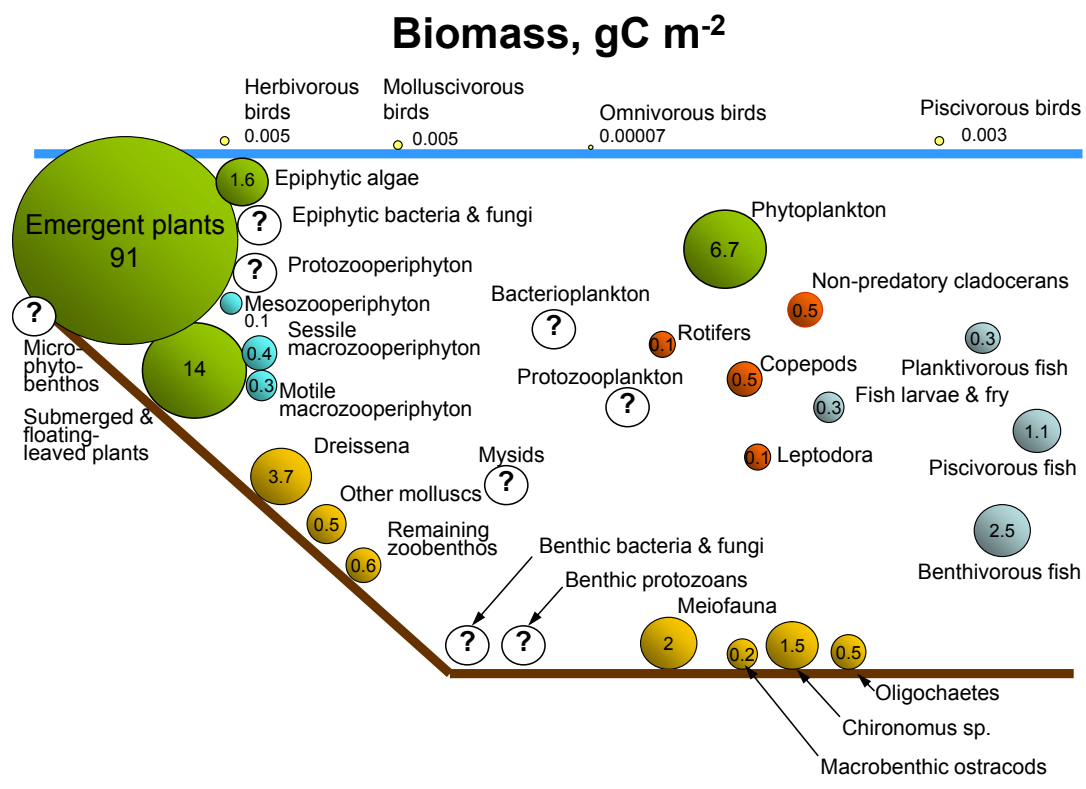

Figure 2.7 Biomass of various components of the Great Lagoon food web.

production, and respiration were, both in the water column and in the sediment, higher than those of all the other food web components. Out of about $1000 \mathrm{gC} \mathrm{m}^{-2} \mathrm{yr}^{-1}$ organic matter supplied to the system and available to consumers, heterotrophs respired about $580 \mathrm{gC} \mathrm{m}^{-2} \mathrm{yr}^{-1}$. Bacteria and fungi accounted for more than $60 \%$ of that, further $10 \%$ being used by protists. Thus, metazoan animals utilised less than $30 \%$ of the organic matter supply respired by heterotrophs.

The role of benthic and planktonic communities in the overall matter and energy flow in the ecosystem was similar. Benthos and plankton were found to be responsible for utilisation of 46 and $47 \%$ of the organic matter used up the heterotrophic part of the biota, respectively, the periphyton and fish utilising 4 and $3 \%$, respectively. The higher biomass of the benthic organisms was counterbalanced by a higher metabolic rate of the plankters.

From the standpoint of fisheries management in the Lagoon, it may be interesting to compare production of benthic invertebrates and plankters (Fig. 2.8), as both groups constitute the basic food of non-predatory fish. Production of the metazoan zooplankton in the Great Lagoon was estimated at about $25 \mathrm{gC} \mathrm{m}^{-2} \mathrm{yr}^{-1}$, production of the zoobenthos amounting to about $37 \mathrm{gC} \mathrm{m}^{-2} \mathrm{yr}^{-1}$. After deducting the production of rotifers and meiobenthos, 


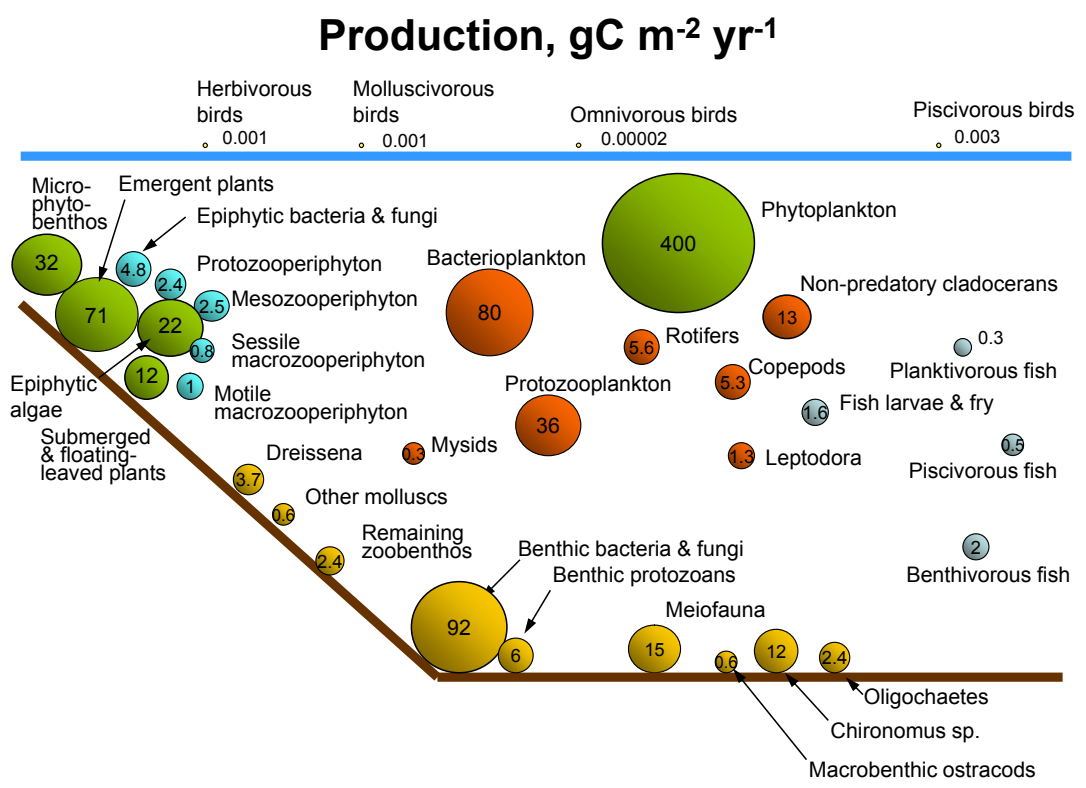

Figure 2.8 Production of various components of the Great Lagoon food web.

which owing to their small size, do not contribute much to the fish food, production of the crustacean zooplankton and the macrozoobenthos may be estimated at about 20 and about $22 \mathrm{gC} \mathrm{m}^{-2} \mathrm{yr}^{-1}$, respectively. As the two values are close, the substantial (several-fold) domination of landings by benthivorous fish species over planktivorous ones may be puzzling. The apparent contradiction is explained by the fact that a considerable part of production of the crustacean zooplankton is consumed by larvae and fry of all the fish species, including benthivores and predators. The amount of food consumed by larvae and fry of all the fish species was almost 10 times that consumed by adult and juvenile planktivores. An additional effect is the zooplankton export to the Pomeranian Bay. As mentioned above, the export accounted for 10 to $30 \%$ of the crustacean zooplankton production.

The Great Lagoon ecosystem produced about $420 \mathrm{gC} \mathrm{m}^{-2} \mathrm{yr}^{-1}$ of non-living organic matter in the form of faeces and remains of plants and animals. These, together with allochthonous organic matter, constituted a substantial food resource for decomposers (Fig. 2.9). Detritus consumption in the Lagoon was estimated at about $590 \mathrm{gC} \mathrm{m}^{-2} \mathrm{yr}^{-1}$ and was similar to the biomass consumption estimated at about $570 \mathrm{gC} \mathrm{m}^{-2} \mathrm{yr}^{-1}$. The detritus consumption was dominated (about 75\%) by bacteria. 


\section{Dead organics, $\mathrm{gC} \mathrm{m}^{-2} \mathrm{yr}^{-1}$}

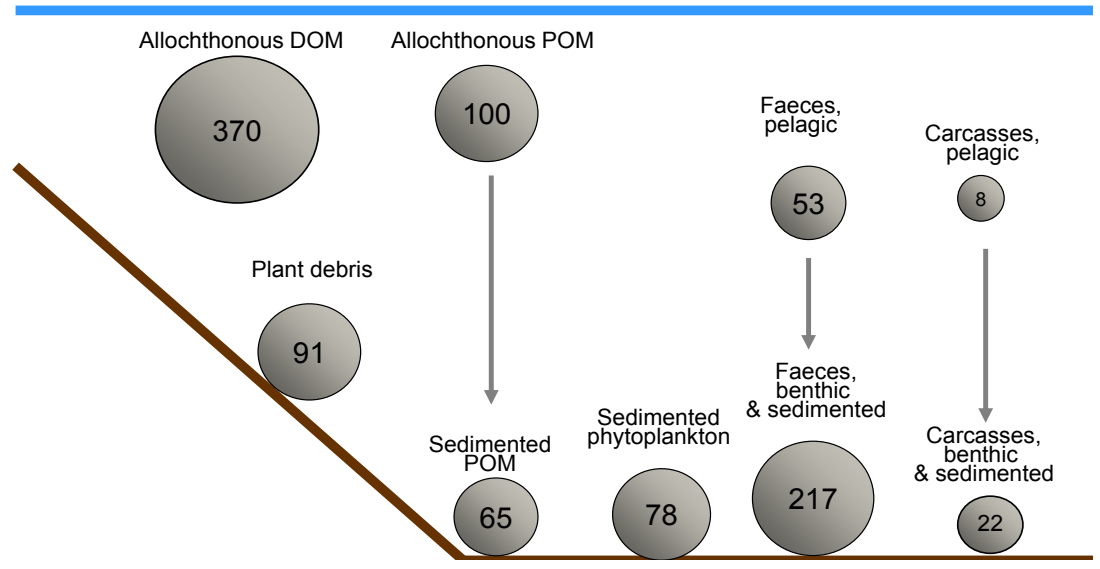

Figure 2.9 Input and production of non-living organic matter in the Great Lagoon. Note internal detritus fluxes between certain components due to sedimentation.

\subsubsection{Composition of Food Consumed by Individual Components of the Lagoon Biotic Community}

The food composition as shown by the model, is a result of selecting the values of $F_{i j}$ and production of individual food web components, adopted for the purpose of modelling. It was in a few cases only (Chironomus sp., fish) that the food composition as defined by the model could be compared with the empirical data from the Great Lagoon. However, even in those cases the verification could not be deemed decisive due to the presence of numerous factors affecting results of food composition studies (year and season, area, age of animals examined, identifiability of diet items and their amenity to weighing, etc.). Thus, the food composition of ecosystem components determined by the model should be treated with utmost caution and regarded as hypothetical only, and in need of further verification. On the other hand, it does not seem possible to obtain exhaustive information on animal feeding solely by analysing alimentary tract contents. It cannot be expected that diet items such as protists, bacteria, naked rotifers, and other small invertebrates, organic remains, etc. would be correctly identified and quantified by microscopic examination only. Moreover, it does not seem possible to analyse the food of all the trophic web components in synchrony. Thus, determination 
of food composition of all the trophic web components by means of a model in which energy budgets of all the components are balanced may be treated as a valuable method with which to complement empirical studies. Application of the stable isotope technique would be extremely helpful for the analysis of trophic relationships (Lajtha and Michener, 1994; Fry, 2006), but the stable isotope-based studies are only at their infancy in Poland (Sokołowski, 2009) and have not been so far carried out in the Great Lagoon.

When estimating food composition, it had to be remembered that numerous components of gut contents, invisible or rapidly digested (particularly the microorganisms) had to be consumed in passing, e.g., when an animal was grazing on the phytoperiphyton or microphytobenthos. The food of suspension feeders consists not only of an appropriate seston fraction, e.g., the sedimenting phytoplankton, but contains also a rich bacterial flora decomposing the phytodetritus. When feeding on plants, herbivorous birds take up also the periphyton, including invertebrates. Thus the data on food composition of the aquatic organisms (based mainly on Monakov, 1974; 1998) had to be appropriately adjusted.

In the model, the bacterioplankton fed on allochthonous DOM, allo- and autochthonous POM as well as phytoplankton-derived food, the three items being taken up in more or less similar proportions (Table 2.13). The food of protists, rotifers, non-predatory cladocerans, and copepods was dominated (about 50\% or more) by the phytoplankton. The bacterioplankton was an important diet item for protists, rotifers, and cladocerans (15-25\% contribution to the diet). The third (in addition to the phyto- and bacterioplankton) major food item for rotifers, cladocerans, and copepods were protists. Zooplankton, primarily non-predatory cladocerans, contributed $85 \%$ to the food of the predatory cladoceran Leptodora kindti. Meiobenthic animals could be an additional food item for L. kindti, which the cladoceran could pick up from the sediment surface. Mysids showed the most diverse food. The major components were microalgae which contributed more than half of the food and were collected from the near-bottom water layer (sedimenting phytoplankton), from the sediment surface (microphytobenthos), from the water column (phytoplankton), and from aquatic vegetation (phytoperiphyton). The animal food (primarily the meiobenthos) accounted for about a quarter of the food, the remainder consisting of particulate organic matter of diverse origin.

In the periphyton, all the components except the sessile macrozooperiphyton derived most of their food from the periphyton itself (Table 2.14). The major food sources for periphytic bacteria and fungi included phytoperiphyton and dead macrophyte tissues. Food of pelagic origin contributed less than $10 \%$ of the entire food. Periphytic protists fed primarily on phytoperiphyton and periphytic bacteria and fungi, a few per cent of their food only being obtained from the water column. According to the model, the mesozooperiphyton fed primarily on the phytoperiphyton, protists, and dead macrophyte tissues. About 30\% 
The Szczecin Lagoon Ecosystem:

The Biotic Community of the Great Lagoon and its Food Web Model

Table 2.13 Food composition (\%) of the planktonic components of the food web.

\begin{tabular}{|c|c|c|c|c|c|c|c|}
\hline 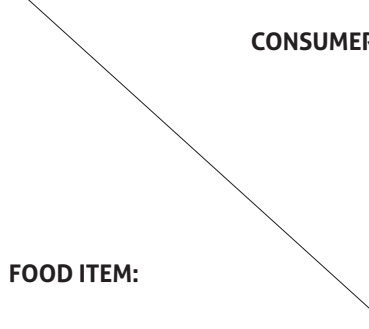 & 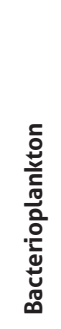 & 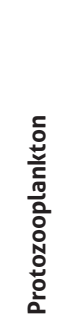 & 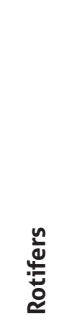 & 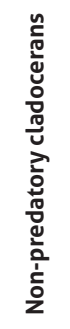 & 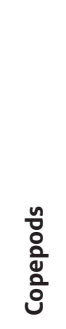 & 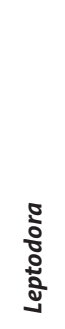 & 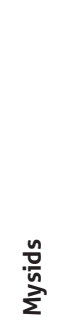 \\
\hline \multicolumn{8}{|l|}{ Planktonic: } \\
\hline Allochthonous POM & 8.2 & 3.0 & 0.3 & 0.7 & 0.2 & & 0.7 \\
\hline Allochthonous DOM & 33.4 & & & & & & \\
\hline Phytoplankton & 32.9 & 60.9 & 48.6 & 50.0 & 55.3 & & 7.8 \\
\hline Bacterioplankton & & 24.5 & 14.6 & 24.6 & 5.3 & & \\
\hline Protozooplankton & & 6.6 & 33.1 & 18.0 & 23.9 & & \\
\hline Rotifers & & & 0.9 & & 3.7 & 22.1 & 5.5 \\
\hline Non-predatory cladocerans & & & & & 2.6 & 49.1 & 4.2 \\
\hline Copepods & & & & & 0.7 & 13.7 & 1.7 \\
\hline Leptodora & & & & & & & 1.3 \\
\hline Faeces, pelagic & 20.1 & 3.7 & 1.9 & 5.1 & 4.0 & & 0.8 \\
\hline Carcasses, pelagic & 5.4 & 1.2 & 0.6 & 1.6 & 3.8 & & 1.9 \\
\hline \multicolumn{8}{|l|}{ Epiphytic: } \\
\hline Epiphytic algae & & & & & & & 1.4 \\
\hline Epiphytic bacteria \& fungi & & & & & & & 0.4 \\
\hline Protozooperiphyton & & & & & & & 0.2 \\
\hline Mesozooperiphyton & & & & & & & 0.2 \\
\hline \multicolumn{8}{|l|}{ Benthic: } \\
\hline Sedimented allochthonous POM & & & & & & & 0.4 \\
\hline Sedimented phytoplankton & & & & & & & 25.3 \\
\hline Microphytobenthos & & & & & & & 20.5 \\
\hline Meiofauna & & & & & 0.5 & 15.0 & 15.1 \\
\hline Remaining zoobenthos & & & & & & & 0.8 \\
\hline Plant debris & & & & & & & 5.9 \\
\hline Faeces & & & & & & & 4.2 \\
\hline Carcasses and remains & & & & & & & 1.5 \\
\hline
\end{tabular}


Table 2.14 Food composition (\%) of the epiphytic components of the food web.

\begin{tabular}{|c|c|c|c|c|c|}
\hline$x$ & 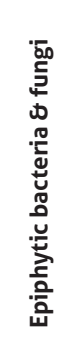 & 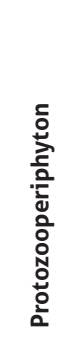 & 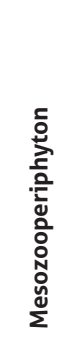 & 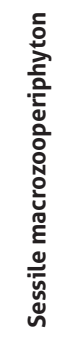 & 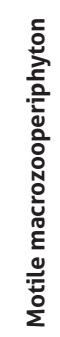 \\
\hline \multicolumn{6}{|l|}{ Planktonic: } \\
\hline Allochthonous POM & 1.4 & 1.1 & 1.3 & 1.5 & 0.7 \\
\hline Allochthonous DOM & 2.6 & & & & \\
\hline Phytoplankton & & 4.4 & 22.4 & 6.4 & 19.7 \\
\hline Bacterioplankton & & 2.2 & 1.1 & 2.4 & \\
\hline Protozooplankton & & & & 10.9 & \\
\hline Rotifers & & & & 6.7 & \\
\hline Non-predatory cladocerans & & & & 5.8 & \\
\hline Copepods & & & & 2.4 & \\
\hline Faeces, pelagic & 4.3 & 8.1 & 4.0 & 1.8 & \\
\hline Carcasses, pelagic & 1.0 & 2.6 & 1.0 & 2.6 & \\
\hline \multicolumn{6}{|l|}{ Epiphytic: } \\
\hline Epiphytic algae & 56.5 & 43.4 & 37.7 & 3.3 & 27.8 \\
\hline Epiphytic bacteria \& fungi & & 34.4 & 5.4 & 2.9 & 6.8 \\
\hline Protozooperiphyton & & 3.9 & 13.6 & 3.5 & 0.7 \\
\hline Mesozooperiphyton & & & 1.6 & 29.6 & 19.1 \\
\hline Sessile macrozooperiphyton & & & & & 4.5 \\
\hline Motile macrozooperiphyton & & & & 7.4 & 3.5 \\
\hline \multicolumn{6}{|l|}{ Benthic: } \\
\hline Emergent plants & 2.5 & & & & \\
\hline Submerged \& floating-leaved plants & 0.4 & & & & 3.3 \\
\hline Microphytobenthos & & & & & 1.1 \\
\hline Remaining zoobenthos & & & & 13.2 & 4.6 \\
\hline Plant debris & 31.4 & & 11.9 & & 8.4 \\
\hline
\end{tabular}


of the mesozooperiphyton food were obtained from the water column (mainly the phytoplankton). The motile macrozooperiphyton fed on phytoperiphyton, phytoplankton, mesozooperiphyton, live and dead macrophyte tissues, and to some extent also on periphytic bacteria and fungi as well as macrozooperiphytic animals. Pelagic components (phytoplankton) accounted for about $20 \%$ of the motile macrozooperiphyton food. On the other hand, the food of the sessile macrozooperiphyton represented primarily by the predatory hydrozoan Cordylophora caspia, consisted largely of zooplankters. Cladocerans, copepods, rotifers and planktonic protists contributed jointly more than $25 \%$ of the food. Further several per cent were contributed by the phytoplankton, bacterioplankton, and non-living seston. Of the periphytic components, the most important was the mesozooperiphyton. Motile littoral and macrozooperiphytic invertebrates could be important (more than 20\%) in the diet as well. Taken together, the animal food (protists and invertebrates) accounted for almost $80 \%$ of the sessile macrozooperiphyton food.

In the benthos (Table 2.15), the sediment-dwelling bacteria and fungi fed mainly on the autochthonous organic matter in the sediment, primarily faeces and phytodetritus.

In their turn, benthic bacteria and fungi were fed on primarily by the benthic protists and meiofauna. Sedimented phytoplankton and detritus was an additional, important food item for protists and meiobenthos. Those items were consumed also by the pelophilous macrobenthos. Two-thirds of the food of larval Chironomus sp. consisted of the phytoplankton, mainly the algae that sedimented on the bottom from the water column (Wolnomiejski et al., 2000). According to the model, the food of the macrobenthic ostracods and oligochaetes was more diverse, but the detritus, benthic bacteria and fungi, and microphytobenthos were the major constituents as well, and the meiofauna being an additional food source. The littoral macrozoobenthos relied on the pelagic and periphytic food to a much larger extent than the pelophilous macrofauna did. The zebra mussel consumed organic seston half of which was the phytoplankton. About one-third of the food of other molluscs was derived from the water column (mainly the phytoplankton), most of the food being collected from the bottom (mainly the microphytobenthos). The food of the remaining littoral zoobenthos was most diverse and consisted primarily of microphytobenthos, phytodetritus, meiobenthos, and phytoperiphyton.

According to the model, the zooplankton was the dominant item in the food of planktivorous fish and all the fish larvae and fry (Table 2.16). Almost all the fish groups consumed substantial amounts of Chironomus sp. larvae and pupae. Larval Chironomus sp. accounted for more than half of the food of juvenile and adult benthivorous fish. The larvae were the major food item for bream and ruffe in the Great Lagoon (Wolnomiejski and Grygiel, 1994C; 2002). Those fish not adapted to collecting their food from the bottom can catch the pupae of Chironomus sp. and other insects in the water column when the 
Table 2.15 Food composition (\%) of the benthic components of the food web.

\begin{tabular}{|c|c|c|c|c|c|c|c|c|c|}
\hline$x$ & 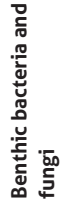 & 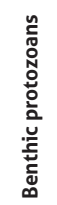 & 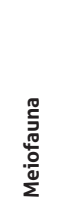 & 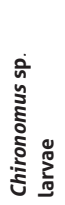 & 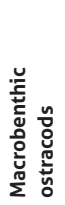 & 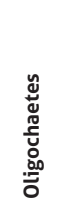 & 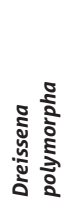 & 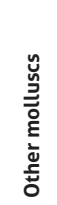 & 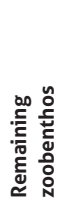 \\
\hline \multicolumn{10}{|l|}{ Planktonic: } \\
\hline Allochthonous POM & & & & 0.2 & & & 4.9 & 2.1 & \\
\hline Phytoplankton & & & & 13.9 & & & 46.7 & 19.2 & \\
\hline Bacterioplankton & & & & & & & 9.8 & 3.9 & \\
\hline Protozooplankton & & & & & & & 6.2 & 1.7 & \\
\hline Rotifers & & & & & & & 1.4 & 0.3 & \\
\hline Non-predatory cladocerans & & & & & & & 0.6 & & \\
\hline Copepods & & & & & & & 0.3 & & \\
\hline Faeces, pelagic & & & & & & & 6.0 & 5.9 & \\
\hline Carcasses, pelagic & & & & & & & 8.5 & 4.4 & \\
\hline \multicolumn{10}{|l|}{ Epiphytic: } \\
\hline Epiphytic algae & & & & & & & & 1.3 & 7.6 \\
\hline Epiphytic bacteria and fungi & & & & & & & & 0.1 & 0.7 \\
\hline Protozooperiphyton & & & & & & & & 0.1 & 0.2 \\
\hline Mesozooperiphyton & & & & & & & & 0.1 & 0.2 \\
\hline Sessile macrozooperiphyton & & & & & & & & & 0.01 \\
\hline Motile macrozooperiphyton & & & & & & & & & 0.01 \\
\hline \multicolumn{10}{|l|}{ Benthic: } \\
\hline $\begin{array}{l}\text { Sedimented allochthonous } \\
\text { POM }\end{array}$ & 11.8 & 9.3 & 4.8 & 2.7 & 1.3 & 9.6 & 0.6 & 1.4 & 2.3 \\
\hline Sedimented phytoplankton & 8.4 & 18.4 & 11.5 & 54.2 & 7.8 & 7.7 & 15.1 & 7.7 & 4.5 \\
\hline $\begin{array}{l}\text { Submerged and floating- } \\
\text { leaved plants }\end{array}$ & & & & & & & & & 1.7 \\
\hline Microphytobenthos & 0.1 & 3.8 & 8.5 & 6.3 & 26.9 & 11.8 & & 21.1 & 23.0 \\
\hline Benthic bacteria and fungi & & 43.5 & 48.7 & 5.6 & 18.3 & 30.2 & & 9.6 & 7.2 \\
\hline Benthic protists & & 1.4 & 3.2 & 0.6 & 6.0 & 1.5 & & & 2.2 \\
\hline Meiobenthos & & 3.7 & 0.6 & 9.5 & 13.9 & 12.2 & & 8.3 & 13.3 \\
\hline Chironomus sp. & & & & & & & & & 0.8 \\
\hline Macrobenthic ostracods & & & & & & & & & 0.2 \\
\hline Oligochaetes & & & & 0.05 & 2.4 & & & & 5.2 \\
\hline Dreissena polymorpha & & & & & & & & & 2.7 \\
\hline Other molluscs & & & & & & & & & 0.4 \\
\hline Remaining zoobenthos & & & & & & & & & 5.3 \\
\hline Plant debris & 19.6 & 4.3 & 6.7 & 2.8 & 3.6 & 4.5 & & 4.1 & 13.0 \\
\hline Faeces & 54.7 & 10.3 & 14.4 & 3.6 & 15.2 & 20.3 & & 7.8 & 1.6 \\
\hline Carcasses and remains & 5.5 & 5.3 & 1.7 & 0.2 & 4.5 & 2.2 & & 1.0 & 8.0 \\
\hline
\end{tabular}


The Szczecin Lagoon Ecosystem:

The Biotic Community of the Great Lagoon and its Food Web Model

Table 2.16 Food composition (\%) of fish.

\begin{tabular}{|c|c|c|c|c|c|c|}
\hline 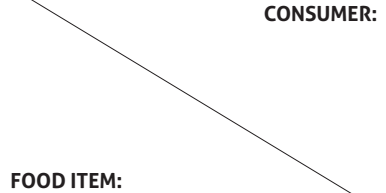 & 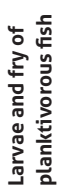 & 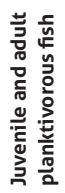 & 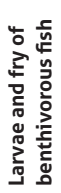 & 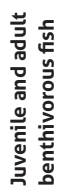 & 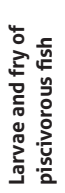 & 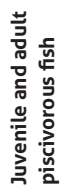 \\
\hline \multicolumn{7}{|l|}{ Planktonic: } \\
\hline Phytoplankton & 0.3 & & 0.5 & & 0.4 & \\
\hline Rotifers & 26.9 & 8.9 & 7.4 & & 8.1 & \\
\hline Non-predatory cladocerans & 47.7 & 20.5 & 36.8 & 4.8 & 39.6 & 6.6 \\
\hline Copepods & 9.7 & 5.8 & 19.4 & 1.9 & 12.2 & 2.7 \\
\hline Leptodora & 2.8 & 4.8 & 1.7 & 4.3 & 2.0 & 0.7 \\
\hline Mysids & 1.0 & 37.0 & 0.2 & 0.8 & 9.3 & 3.0 \\
\hline \multicolumn{7}{|l|}{ Epiphytic: } \\
\hline Epiphytic algae & 0.2 & 0.1 & 1.4 & 0.1 & & \\
\hline Epiphytic bacteria and fungi & 0.1 & & 0.1 & & & \\
\hline Protozooperiphyton & 0.1 & & & & & \\
\hline Mesozooperiphyton & 0.2 & & & & & \\
\hline Sessile macrozooperiphyton & 0.3 & & 0.2 & 0.2 & 0.1 & \\
\hline Motile macrozooperiphyton & 0.4 & & 1.0 & 3.5 & 0.8 & 1.7 \\
\hline \multicolumn{7}{|l|}{ Benthic: } \\
\hline Sedimented phytoplankton & 0.3 & & & 0.1 & 0.2 & \\
\hline Submerged and floating-leaved plants & 0.2 & 0.3 & 1.4 & 1.7 & & \\
\hline Microphytobenthos & 0.1 & 0.1 & 1.6 & 1.4 & & \\
\hline Benthic bacteria and fungi & & & & 0.3 & & \\
\hline Benthic protists & & & & 0.2 & & \\
\hline Meiofauna & 2.3 & 0.4 & 8.8 & 5.7 & & \\
\hline Chironomus sp. larvae & 3.4 & 14.2 & 10.7 & 58.1 & 18.6 & 10.7 \\
\hline Macrobenthic ostracods & 0.2 & 0.6 & 3.3 & 1.9 & 0.2 & \\
\hline Oligochaetes & 0.2 & 0.4 & 1.8 & 2.1 & 0.4 & 0.1 \\
\hline Dreissena polymorpha & 0.1 & 0.4 & 0.2 & 4.1 & & 0.1 \\
\hline Other molluscs & & 0.2 & 0.8 & 1.9 & 0.1 & \\
\hline Remaining zoobenthos & 3.6 & 1.9 & 2.4 & 5.4 & 1.9 & 2.1 \\
\hline Plant debris & & & & 0.7 & & \\
\hline Carcasses and remains & & & 0.3 & 0.8 & & 0.1 \\
\hline \multicolumn{7}{|l|}{ Fish: } \\
\hline Larvae and fry of planktivorous fish & & 0.4 & & & 0.7 & 2.9 \\
\hline Juvenile and adult planktivorous fish & & & & & & 6.2 \\
\hline Larvae and fry of benthivorous fish & & 2.7 & & & 4.6 & 16.9 \\
\hline Juvenile and adult benthivorous fish & & & & & & 35.9 \\
\hline Larvae and fry of piscivorous fish & & 1.0 & & & 0.9 & 7.5 \\
\hline Juvenile and adult piscivorous fish & & & & & & 3.1 \\
\hline
\end{tabular}


pupae are migrating upwards toward the water surface. Of other food items for benthivorous fish, those most important were molluscs and other littoral invertebrates as well as the meiobenthos, consisting mainly of ostracods. Fish accounted for about three quarters of the diet of juvenile and adult predatory fish, the zooplankton and benthos (mainly the larval Chironomus sp.) contributing several per cent each. In the Great Lagoon, those components are important in the food of juvenile perch (Wolnomiejski and Grygiel, 1994b). According to the model, periphytic organisms did not play any major role in fish food; they contributed as little as about 3\% to the diet of benthivorous fish (Table 2.16). This category of organisms was not accounted for at all in the empirical studies on food composition of the Great Lagoon fish. The macrozooperiphyton consists mainly of invertebrate taxa occurring also in the macrobenthos, particularly insect larvae and molluscs. Practically, the provenance (macrobenthos or macrozooperiphyton) of a fish food item cannot be identified with any certainty.

The food of herbivorous birds consisted primarily of soft macrophytes. As already mentioned, periphyton were most probably taken up together with them (Table. 2.17). The molluscivorous birds feed primarily on animal

Table 2.17 Food composition (\%) of birds.

\begin{tabular}{|c|c|c|c|c|}
\hline FOOD ITEM: CONSUMER: & $\begin{array}{l}\text { Herbivorous } \\
\text { birds }\end{array}$ & $\begin{array}{l}\text { Molluscivorous } \\
\text { birds }\end{array}$ & $\begin{array}{l}\text { Omnivorous } \\
\text { birds }\end{array}$ & $\begin{array}{l}\text { Piscivorous } \\
\text { birds }\end{array}$ \\
\hline \multicolumn{5}{|l|}{ Planktonic: } \\
\hline Mysids & 8.9 & 4.0 & 50.7 & \\
\hline \multicolumn{5}{|l|}{ Epiphytic: } \\
\hline Epiphytic algae & 2.7 & 0.7 & & \\
\hline Epiphytic bacteria and fungi & 0.6 & 0.2 & & \\
\hline Protozooperiphyton & 0.3 & 0.1 & & \\
\hline Mesozooperiphyton & 0.3 & 0.1 & & \\
\hline Sessile macrozooperiphyton & 0.5 & 0.2 & & \\
\hline Motile macrozooperiphyton & 0.9 & 0.1 & & \\
\hline \multicolumn{5}{|l|}{ Benthic: } \\
\hline Submerged and floating-leaved plants & 74.7 & 8.6 & & \\
\hline Dreissena polymorpha & & 49.6 & & \\
\hline Other molluscs & & 8.9 & & \\
\hline Remaining zoobenthos & & 24.6 & & \\
\hline Plant debris & 11.1 & 3.0 & & \\
\hline \multicolumn{5}{|l|}{ Fish: } \\
\hline Larvae and fry of planktivorous fish & & & 4.2 & 7.6 \\
\hline Juvenile and adult planktivorous fish & & & & 11.1 \\
\hline Larvae and fry of benthivorous fish & & & 39.4 & 30.5 \\
\hline Juvenile and adult benthivorous fish & & & & 39.7 \\
\hline Larvae and fry of piscivorous fish & & & 5.6 & 11.2 \\
\hline
\end{tabular}


food, more than $80 \%$ of their diet being accounted for by invertebrates, particularly the zebra mussel. The omnivorous birds fed, in addition to the food obtained on land, on mysids and fish larvae and fry. Their diet relied primarily on organisms or waste found on land (not included in the table) as well as on terrestrial insects found in water. The piscivorous birds fed exclusively on fish; half of their food consisted of fry, while juvenile and adult fish made up the other half.

\subsubsection{Trophic Levels}

The trophic position (trophic level, TL) of each consumer category in the Great Lagoon food web was calculated as a weighted average of trophic levels of all constituents of its food increased by 1 . Non-living organic matter, similarly to all the primary producers, were assigned to trophic level 1.

The majority of the food web components were placed between trophic levels 2 and 3 (Fig. 2.10). This TL range was occupied by herbivorous birds, protists, and almost all the invertebrate components. Molluscivorous birds, sessile macrozooperiphyton, Leptodora as well as plankti- and benthivorous fish were placed between trophic levels 3 and 4. The top consumers (TL between 3.9 and 4.5) consisted of omni- and piscivorous birds as well as predatory fish.

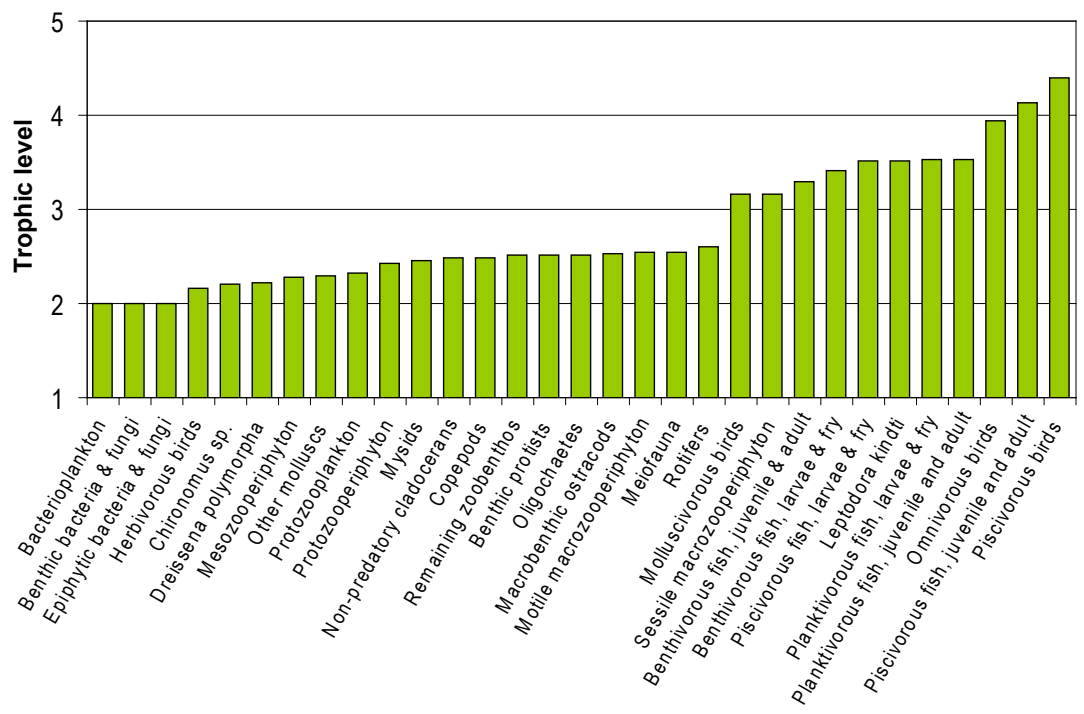

Figure 2.10 Trophic level of consumers in the food web. 


\subsubsection{Biogeochemical Macrofluxes}

The model is a good tool with which to calculate various biogeochemical fluxes (Table 2.18). Some of the calculated fluxes may be useful for comparisons with empirical measurements carried out at the ecosystem level, and for this reason they may be helpful also for the quality assessment of the model and for its improvement. Other fluxes or interactions between them are used to characterise the ecosystem and may be applied in the between-ecosystems comparisons.

In addition to the primary production, it is relatively easy to determine empirically fluxes such as pelagic and benthic community respiration, sedimentation, deposition in sediment, and export from the system, but only few of those fluxes have been quantified in the Great Lagoon.

The pelagic community respiration in the Great Lagoon was measured in the 1960 s by Wiktor (1971) when she determined primary production using the light and dark bottle-based oxygen method. The respiration that may be estimated from her measurement was about $750 \mathrm{gO}_{2} \mathrm{~m}^{-2} \mathrm{yr}^{-1}$, which is approximately equal to $280 \mathrm{gC} \mathrm{m}^{-2} \mathrm{yr}^{-1}$. Considering the increase in eutrophication level of the

Table 2.18 Biogeochemical fluxes in the Great Lagoon. Model estimates.

\begin{tabular}{|l|c|}
\hline & $\mathbf{g C ~}^{-2} \mathbf{~ y r}^{-1}$ \\
\hline Total gross primary production & 657.5 \\
\hline Total net primary production & 537.5 \\
\hline Supply of allochthonous organic matter & 470.0 \\
\hline Total system throughput ${ }^{\text {(TST) }}$ & 2638.3 \\
\hline Total respiration & 704.5 \\
\hline Pelagic community respiration & b \\
\hline Benthic community respiration & \\
\hline Sedimentation & 373.9 \\
\hline Deposition in sediment & 278.2 \\
\hline Catches/Landings & 203.7 \\
\hline Export & 74.9 \\
\hline
\end{tabular}

a sum total of consumption, export (outflow, emergence, catches), respiration, and transformation to detritus of all components

${ }^{b}$ respiration of phyto-, bacterio-, protozoo- and metazoan zooplankton (without mysids)

' respiration of microphytobenthos, benthic bacteria, fungi, protists, meio-, and macrozoobenthos (without respiration of macrophytes and periphyton) 
Great Lagoon taking place from the 1960 s until the end of the 20th century, the pelagic community respiration estimated by the model (about $370 \mathrm{gC} \mathrm{m}^{-2} \mathrm{yr}^{-1}$ ) can be regarded as very plausible.

Regarding the deposition in sediment, Leipe et al. (1998) as well as Meyer and Lampe (1999) demonstrated the lack of recent increase in the sediment thickness in the Szczecin Lagoon and explained this lack by sediment resuspension and removal, the processes counterbalancing sedimentation and matter input. However, maintenance of the navigability of the fairway intersecting the Lagoon calls for continuous dredging, which results in an annual dredge spoils of about 1 million $\mathrm{m}^{3}$ deposited on land (Maritime Office in Szczecin, unpubl. data). Assuming that $1 \mathrm{~m}^{3}$ of the sediment dredged out contains about $200 \mathrm{~kg}$ dry matter, and that $1 \mathrm{~kg}$ dry sediment is equivalent to $107 \mathrm{gC}$ org. (Minning, 2004), the amount of organic carbon removed by dredging can be estimated at $52 \mathrm{gC} \mathrm{m}^{-2} \mathrm{yr}^{-1}$. Therefore, the deposition estimated by the model (about $75 \mathrm{gC} \mathrm{m}^{-2} \mathrm{yr}^{-1}$ ) seems realistic as well.

The lack of any other empirical studies on biogeochemical fluxes in the Great Lagoon prevents any more comprehensive verification of model estimates. Therefore, the need for such studies is very urgent, both for a better understanding of the processes themselves and for the assessment, and improvement, of the performance of models describing the ecosystem.

\subsubsection{Ecological Efficiency}

There are numerous ways with which to characterise the trophic structure of ecosystems or their individual components, and which utilise various terms of energy budgets. The simplest indicators of ecosystem maturity were proposed by Odum (1969; 1971). More complex tools, rooted in information theory and utilising computer techniques, constitute the so-called ecosystem network analysis (Ulanowicz, 1986; Wulff et al., 1989). Their application is progressively increasing in ecological modelling (Christensen, 1995; Christensen et al., 2008). This section highlights only the simplest indicators, easy to calculate with the model results discussed above.

The ecotrophic efficiency $(E E)$ is an indicator characterising the degree to which production of various ecosystem components is utilised in this ecosystem:

$$
E E=\left(M_{2}+\operatorname{Exp}+A c u m+Y\right) / P=1-M_{0^{\prime}}
$$

where $M_{2}$ is mortality due to consumption; Exp is export (removal, emergence); Acum is accumulation in the ecosystem; $Y$ denotes fish catches; and $M_{0}$ is natural mortality. 
Among autotrophs, the highest ecotrophic efficiency was - according to the model -typical of microalgae, primarily the phytoperiphyton (Fig. 2.11). The phytoperiphyton ecotrophic efficiency of more than 0.95 may raise some reservations, as field observation show that, at the end of the growing season, much of the periphytic biomass is deposited on the bottom where it most likely dies off and enters the non-living organic matter pool. This process, a form of natural mortality, has not been quantified so far, but considering the relatively high periphyton biomass at the end of the growing season, it is likely that it exceeds 0.04 (4\%) of the phytoperiphyton production suggested by the model. The relatively low EE (about 0.75 ) of the phytoplankton seems plausible, as it is related to sedimentation some of the phytoplankton biomass to the bottom and its transfer to the deposited phytoplankton pool. Although observations show some of the deposited phytoplankton cells to be viable for some time (Wolnomiejski et al., 2000), the deposited phytoplankton was in the model classified with the non-living organic matter, as most of the phytoplankton reached the bottom of the relatively deep central part of the Lagoon where there are no conditions for photosynthesis. The very low ecotrophic efficiency of macrophytes, particularly the emergent ones, is also consistent with expectations.

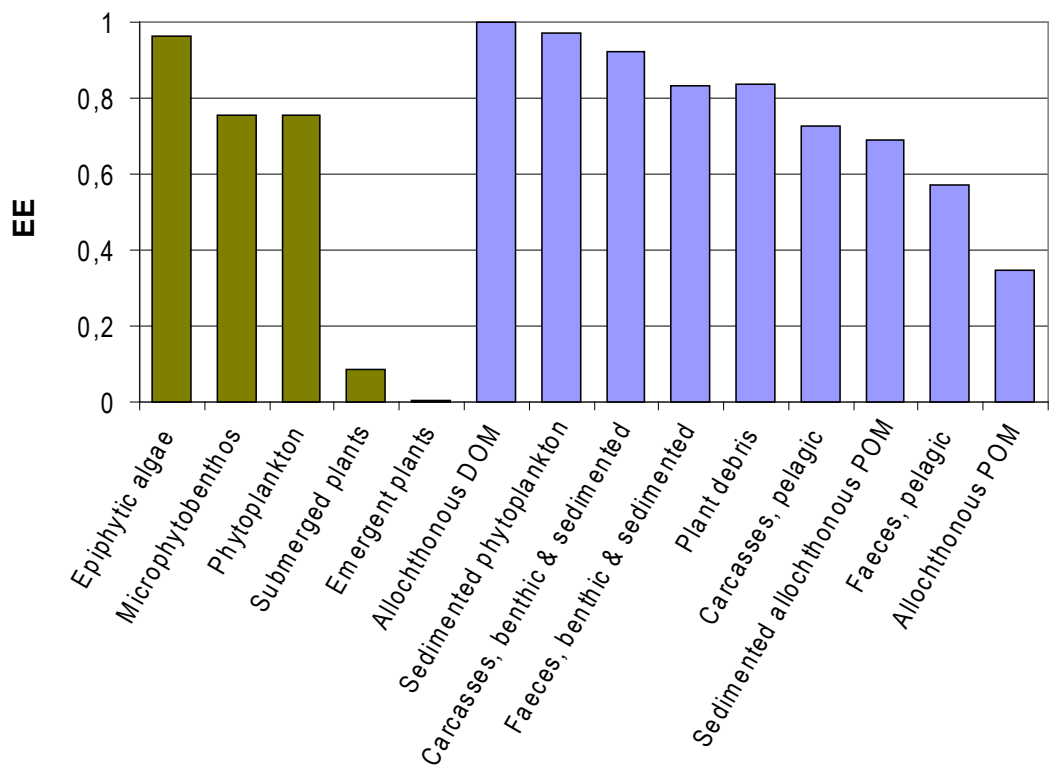

Figure 2.11 Ecotrophic efficiency $(E E)$ of autotrophs and non-living organic matter. 
Of the components representing non-living organic matter, the highest utilisation in the ecosystem was typical of the autochthonous components, particularly the deposited phytoplankton and animal remains (Fig. 2.11). The high (1.0) EE of the allochthonous DOM resulted from the export of the total pool of unused DOM. In reality, as little as $22 \%$ of the DOM input to the Great Lagoon was consumed. The allochthonous POM, too, was poorly utilised (EE of 0.35) while in the water column. Only when it sedimented to the bottom, its utilisation increased.

Most of heterotrophic components showed a high ecotrophic efficiency, exceeding or close to 0.9 (Fig. 2.12). Particularly high EEs were shown for periphytic components (the mesozoo- and protozooperiphyton as well as periphytic bacteria and fungi), which -in the light of the comments above pertaining to the phytoperiphyton - allows to conclude that either the selection of $F_{i j}$ values for the periphyton or the production of some periphytic components entered into the model had not been appropriate. The drawback here was the lack of empirical data on zooperiphyton feeding, including the contribution of pelagic components to the food of the periphytic ones, as well as a paucity of research on periphyton production rate. The ecotrophic efficiency of the bacterio- and protozooplankton as well as benthic bacteria, fungi, and protists (about 0.95) stems also from assumptions adopted by the authors without any empirical backing.

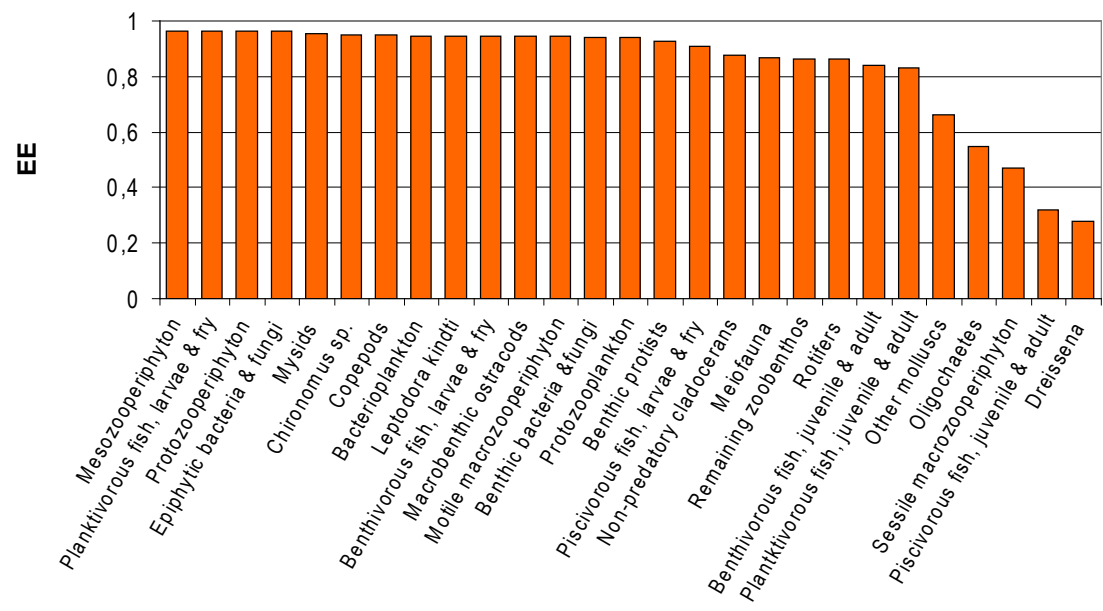

Figure 2.12 Ecotrophic efficiency $(E E)$ of heterotrophs. 
Six components showed somewhat lower ecotrophic efficiencies, between 0.9 and 0.8. Those components included cladocerans, rotifers, the meiobenthos, littoral benthos (other than molluscs) as well as plankti- and benthivorous fish. In the case of invertebrates (the first four components), reservations identical to those put forth for the periphyton can be presented, namely insufficient knowledge on the feeding of potential consumers of those categories as well as inadequate estimates of their production rates. On the other hand, somewhat lower EEs of adult and juvenile plankti- and benthivorous fish stemmed from assigning their reproductive materials to production destined to the detritus.

Low ecotrophic efficiency (0.3-0.7) was shown by molluscs (including the zebra mussel) and the sessile macrozooperiphyton, which can be explained by their effective protection from predation in the form of shells and external skeletons. The relatively low EE of oligochaetes (0.55) is difficult to explain. Perhaps the oligochaetes, living among the sediment particles, are protected from predation better than other organisms and succumb to natural mortality much more than other animals. Most of the oligochaete biomass is confined to the muddy bottom where they are available only to the obligatory benthophages, mainly bream. On the other hand, bream show a distinct preference towards feeding on large, more caloric pelophilous larvae of Chironomus which are much more abundant in the sediment. However, adoption of a too high oligochaete production in the model cannot be ruled out.

Particularly low ecotrophic efficiency was shown for the predatory fish. As already mentioned, this is most likely an artefact produced by underestimation of the true catches of those fish.

The most straightforward indicators characterising the ecosystem maturity is the net system production (GPP-R) and the primary production to respiration ratio (GPP/R) (Odum, 1971). The primary production to respiration ratio of the Great Lagoon close to unity (Table 2.19 ) evidences the ecosystem to have reached a high level of maturity. The negative net system production results from a substantial supply of organic matter from the outside. The absolute value of net production is low and corresponds to $7 \%$ of GPP.

Certain ecological indicators used to characterise ecosystems pertain to total biomass of the entire biota. However, not all the components of the Great Lagoon biota were amenable to biomass determination. To provide at least crude estimates of those indicators, the missing biomasses of the phytoplankton, bacteria, and protists were approximated in a simplified manner, assuming their P/B values at 75, 50, and $150 \mathrm{yr}^{-1}$ (as in Table 2.5). Thus, the total biomass of the Great Lagoon biota was estimated at about $143 \mathrm{gC} \mathrm{m}^{-2}$. An example of an indicator related to the total biomass is B/TST, i.e., biota biomass referred to unit ecosystem energy flow. It is believed that the B/TST 
Table 2.19 Ecological indicators characterising the Great Lagoon ecosystem.

\begin{tabular}{|c|c|}
\hline 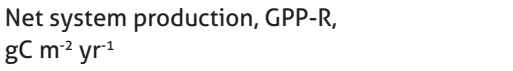 & -47 \\
\hline $\begin{array}{l}\text { Total GPP/R, } \\
\text { unitless }\end{array}$ & 0.933 \\
\hline $\begin{array}{l}\text { Total biomass, B } \\
\mathrm{gC} \mathrm{m}^{-2}\end{array}$ & 142.7 \\
\hline $\begin{array}{l}\text { Total NPP/B, } \\
\mathrm{yr}^{-1}\end{array}$ & 3.77 \\
\hline $\begin{array}{l}\text { Total biomass/total system throughput, } \\
\text { yr }\end{array}$ & 0.054 \\
\hline $\begin{array}{l}\text { Detritus consumption/biomass consumption, } \\
\text { unitless }\end{array}$ & 1.03 \\
\hline $\begin{array}{l}\text { Efficiency of fisheries, Y/NPP, } \\
\text { unitless }\end{array}$ & 0.001 \\
\hline $\begin{array}{l}\text { Fisheries yield, } \\
\text { tonnes ha-1 }\end{array}$ & 56 \\
\hline
\end{tabular}

increases with the increasing ecosystem maturity (Christensen et al. 2005). In the Great Lagoon, the annual estimate of B/TST was about 0.05. According to Christensen et al. (2005), the increasing maturity of the ecosystem may be expected to be also accompanied by an increasing primary production to total biomass ratio (NPP/B). In the Great Lagoon, the ratio was about $3.8 \mathrm{yr}^{-1}$. In the Lagoon, the value of the two indicators is strongly affected by the presence of macrophytes the biomass of which accounted for about $80 \%$ of the total biota biomass. Under such conditions, the utility of ecosystem maturity indicators based on the total biomass seems doubtful, as they could lead to contradictory conclusions. Particularly the later index (NPP/B) appears questionable. For example, the absence of macrophytes does not have to be a sign of ecosystem maturity, and their abundance does not have to signify the immaturity of an ecosystem.

As already mentioned in Section 2.3.8, consumption of non-living organic matter in the Great Lagoon was very similar to the biomass consumption, the ratio between the two being 1.03 .

The fishing efficiency of ecosystem can be expressed in a variety of ways. Catches amounting to $0.56 \mathrm{gC} \mathrm{m}^{-2} \mathrm{yr}^{-1}$, equivalent to $56 \mathrm{~kg}$ of fish caught from a hectare during the year, evidence a high production available to fisheries. With respect to the net primary production, the fishing efficiency was $0.1 \%$. Considering that the fish catches in the Great Lagoon were most probably underestimated, the true value of the indicators pertaining to the fishing efficiency could be higher than those reported in Table 2.19. 


\subsection{Discussion}

\subsubsection{The Model Concept Problem}

When setting off to develop a food web model, a researcher has to decide on the number and identification of functional groups, and on the way the equations in the model will be linked. The functional group identification for the purposes of a food web model will be understandably based on feeding mode of an organism (organisms) and the role of the latter as a food for other consumer groups. Important are also considerations such as the habitat occupied by an organism (water column, sediment, littoral zone, other organisms, etc.) as well as taxonomic affinity and size, translating into biological traits and metabolic rates. An additional subjective factor affecting the model structure is the level of knowledge of biology of individual organism categories and personal interests of a researcher. The number of model components is usually a trade-off between the required level of detail of the model and its operating capacity. A low number of components oversimplifies the trophic web structure, whereby individual characteristics of the ecosystem become obliterated and the individual components, combining very different species, become very abstract units the bioenergetic parameters of which require summing up or averaging, and may change depending on proportions in the species composition of a component. On the other hand, a high number of components identified, in addition to increasing the number of terms in the model, increases - in a geometric progression - the number of possible interactions between the components, thereby complicating the control of the system being modelled and extending the time necessary for preparing successive scenarios.

The 45 components of the Great Lagoon food web model, including 36 live components, is a very high number for mass-balance models of aquatic ecosystems, as can be seen from the review of a number of relevant publications which appeared during the recent two decades (Fig. 2.13). Particularly the number of components involving non-living organic matter (9) is higher than that in other models (usually 1-3). In the Great Lagoon model presented, the number of species included in different live components varies greatly. Some components consist of a high number of species, or even higher taxa (phytoplankton, meiobenthos, bacteria, protists) which may be even linked by significant within-group trophic interactions (e.g., protists). Other components are made up by a few taxonomically related species (e.g., copepods, ostracods), still others consisting of a single species each (Leptodora kindti, Chironomus sp., Dreissena polymorpha). The reason underlying such was, on the one hand, inadequate knowledge on some groups of organisms and the necessity of 
reducing the number of components, and - on the other - the intention of having a closer look at selected taxa, particularly benthic invertebrates, fish, and birds. In the case of fish, a group of organisms very important for the ecosystem functioning and undergoing a particularly extensive ontogenetic size changes accompanied by changes in food composition and feeding mode, different life stages were assigned to different food web components (larvae and fry versus juveniles and adults).

When constructing a food web model, energy budget components may be linked together starting from the bottom of the trophic pyramid bottom (a 'bottomup' approach), whereby the production is transferred, as food, to consumers at higher levels, according to the energy flow direction. This approach was adopted in, e.g., food web models of a number of estuaries (Baird and Ulanowicz, 1993) and Atlantic US coastal ecosystems (Link et al., 2006; the EcoNetwrk model). This is the approach adopted in this work as well. Another possibility is to arrange the equations starting from the top of the trophic pyramid (a 'top-down' approach)

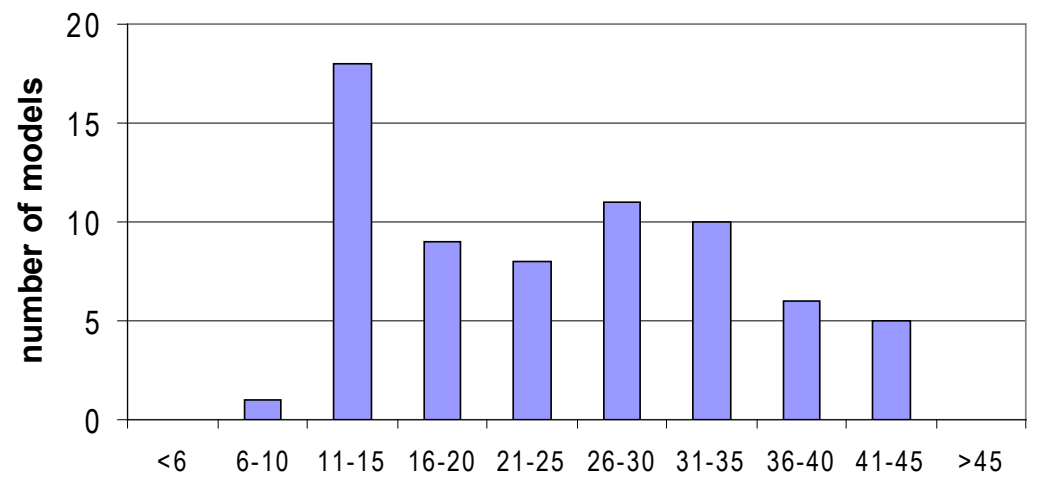

number of functional groups

Figure 2.13 Number of food web functional groups in 68 aquatic ecosystem models presented in 48 publications.

Data sources: Angelini and Agostinho, 2005; Arreguin-Sanchez et al., 2003; Baird and Ulanowicz, 1993; Barausse et al., 2009; Bradford-Grieve et al., 2003; Cerco et al., 2010; Chen et al., 2008; Coll et al., 2006; Cornejo-Donoso and Antezana, 2008; Cruz-Escalona et al., 2007; Darwall et al., 2010; Duan et al., 2009; Fetahi and Mengistou, 2007; Guenette et al., 2008; Harvey et al., 2003; Hauputhantri et al., 2008; Heymans and Baird, 2000; Heymans et al., 2007; Kissler, 2009; Kitchell et al., 2000; Lachica-Alino et al., 2006; Libralato and Solidoro, 2009; Lin et al., 1999; Lin et al., 2006; Link et al., 2006; 2009; Megrey and Aydin, 2009; Moloney et al., 2005; Monaco and Ulanowicz, 1997; Morales-Zarate et al., 2004; Moreau et al., 2001; Morissette et al., 2009; Osterblom et al., 2007; Patricio and Marques, 2006; Pinnegar et al., 2005; Rochette et al., 2009; Rosado-Solorzano and Guzman del Proo, 1998; Rybarczyk and Elkaim, 2003; Rybarczyk et al., 2003; Sandberg, 2007; Sandberg et al., 2000; Skurzak, 2009; Tomczak et al., 2009; Vega-Candejas and Arreguin-Sanchez, 2001; Vidal and Pauly, 2004; Villanueva et al., 2006; Villanueva et al., 2008; Zetina-Rejon et al., 2003 
and to determine food demand of the successive levels of the system in the descending order. This is the way the popular ECOPATH model is constructed (Ecopath with Ecosim (EwE) software, Christensen and Pauly, 1992; Christensen et al., 2008), applied primarily to show the position of fish and fisheries in the ecosystem context (Christensen and Pauly, 1993, 2004; Vasconcellos et al., 1997 and many others; Fig. 2.14).

The two model types produce an identical final effect, i.e., a balanced set of equations describing energy (matter) flow in an ecosystem. However, each model type has its specific properties. The bottom-up models require the operator to enter information on the fate of production of each biotic component at the ascending order of trophic levels. The drawback is that the fate of production of individual food web components, and particularly the quantification of production utilisation by other components, are seldom targeted by direct studies, therefore the relevant values needed by the model are usually calculated indirectly or selected by the trial and error method.

The situation is somewhat easier in the top-down models, because - rather than utilisation of production - the operator has to enter the components' food composition, the food being usually studied directly, at least at the upper trophic levels (fish, birds). However, proceeding from selected top trophic components down the trophic pyramid to its bottom, in a direction opposite to that of energy flow, creates a risk of ignoring important trophic web links which may

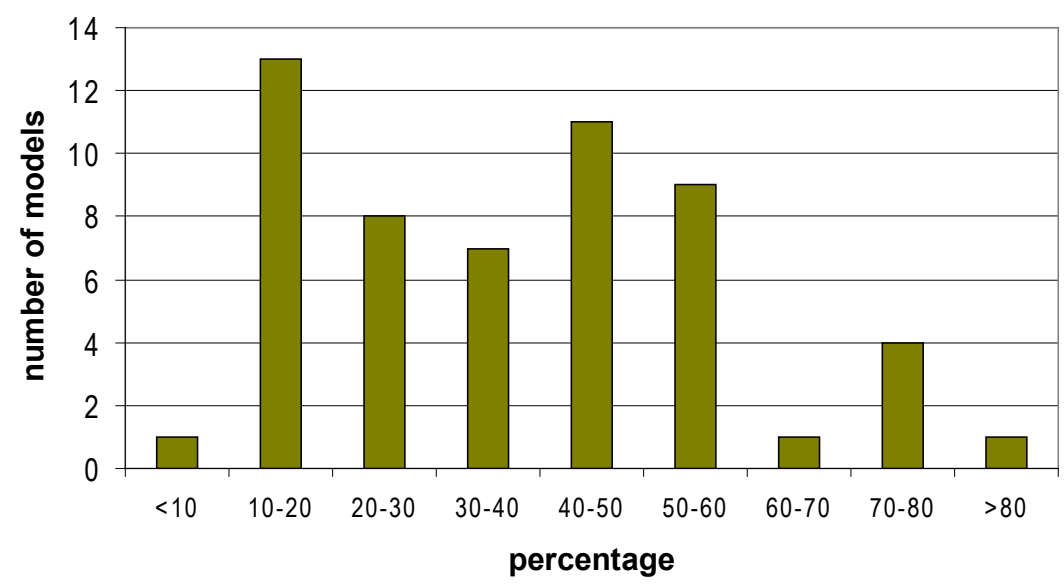

Figure 2.14 Percent contribution of fish components to the total number of food web components in 55 ecosystem models constructed with the ECOPATH software. In the Great Lagoon food web model, fish account for $13 \%$ of all the components. Data sources as in Fig. 2.13. 
be bypassed by trophic chains leading to top predators. Most frequently such overlooked (or ignored) food web components are microorganisms (bacteria, protists) and the meiobenthos.

Although a competent researcher is capable of including all the important categories in either model type, a surprisingly high number of studies involving the ECOPATH programme ignored the components mentioned above. Only 12 out of the 41 inspected models, published in the recent two decades, included bacteria and protists, 14 including the meiobenthos. And yet, as shown by this study as well as by publications considering those components in the trophic web structure, microbes and meiobenthos may be responsible for $40-90 \%$ of respiration of the entire biota. Ignoring them in models seriously distorts different indicators developed to characterise the ecosystem, such as the total respiration, total system throughput, net system production, primary production to respiration ratio, total biomass of the biota, etc. Unfortunately, analyses and comparisons of ecosystems, based on such distorted indicators, have no merit whatsoever.

An additional shortcoming of ECOPATH, when it is used to modelling the entire ecosystem, is the fact that - in the case of primary producers - it uses the net production and consequently ignores the respiration of phytoplankton, phytobenthos, and phytoperiphyton. As a result, respiration of the pelagic or benthic (littoral) community cannot be directly compared with field data, as these include also respiration of plant components.

Although less experienced authors frequently do not pay enough attention to such details, a seasoned researcher is capable of dealing with those ECOPATH shortcomings and supplement or adjust the model accordingly. Due to its clarity, a user-friendly interface, a rich armoury of system analysis tools (e.g., the Network Analysis Plugin), and the general availability of the EwE software (www.ecopath.org), ECOPATH has become a standard in aquatic ecosystem modelling, particularly in fisheries-oriented models. Its great advantage is a possibility of switching from a mass-balanced static model (ECOPATH) to time dynamic (ECOSIM) and spatial (ECOSPACE) modelling. For this potential to be utilised to its full capacity, it is important that a starting, correctly constructed, mass-balance model, is available. Towards this end, a food web model developed with the use of the ECOPATH software is confronted with a bottom-up model, for example such as the model of the Great Lagoon food web described in this work.

\subsubsection{The Quality and Availability of Empirical Data}

To assess the quality of data sources used to develop the model described in this work, a system proposed by the User Guide of the ECOPATH with ECOSIM 
modelling software (Christensen et al., 2005) was used. Four data categories were assessed: biomass, P/B (Q/B), food composition, and catches. Individual parameters were assigned an index (from 0.0 to 1.0) depending on the origin and accuracy of the data used: from inferred to compilation to original (measurements and analyses conducted by the authors). The assessment criteria are shown in Table 2.20 .

In the Great Lagoon, the best quality data were those on biomasses and fish catches (Table 2.21). Most of the data were derived from actual studies conducted in the Lagoon, although the scope of those studies not always allowed the assessment to be highly accurate. Unfortunately, there were no local biomass data on certain components (primarily microorganisms). The quality of $\mathrm{P} / \mathrm{B}$ and food composition data scored in the assessment lower than the biomass did. Almost all the P/B values used were derived from literature compilations. The provenance of data on food composition of various food web components was very diverse. In the case of fish food, the data were collected in the in situ quantitative studies; the in situ qualitative studies supplied data on food composition of larval Chironomus sp., while the literature was the only source of information on feeding of the remaining components. With respect to food composition of invertebrates, particularly useful was the study of Monakov (1998). In all the data categories, the lack of information was most acutely felt with respect to microorganisms.

The review above allows to conclude that, to increase the accuracy and reliability of future estimates of matter/energy flows in the food web of the Great (Szczecin) Lagoon, particularly urgent are studies on biomass, production, and feeding of various groups of microorganisms inhabiting the area, and studies on feeding of planktonic and benthic invertebrates. It would be very useful to have access to current data on primary production of the phytoplankton, phytoperiphyton, and microphytobenthos in the Lagoon, as those groups - together constituting the base of the trophic pyramid are the most important suppliers of easily assimilable organic matter in the ecosystem. Despite the high scores assigned to the phytoplankton, the data on its production used in the model were not collected during the period of study and were not entirely satisfactory in terms of methodology of their acquisition. Particularly useful would also be results of more comprehensive studies on the periphytic community and the littoral fauna. The relevant studies have been so far constrained by a low number of sites and a very short periods of study. Trophic links within those communities are far from understood as well.

The average collective score of all the four data categories was 0.421 . It corresponds almost ideally to the mid-point (0.420) of the score range of 0.164-0.676 found by Coll et al. (2006) in their review of 50 applications of the ECOPATH model. 
The Szczecin Lagoon Ecosystem:

The Biotic Community of the Great Lagoon and its Food Web Model

Table 2.20 A scale for classification of the quality of data sources used in the ECOPATH with ECOSIM model (Christensen et al., 2005).

\begin{tabular}{|c|c|}
\hline Parameter & Score \\
\hline \multicolumn{2}{|l|}{ Biomass } \\
\hline Missing parameter (estimated by model) & 0 \\
\hline From other models & 0 \\
\hline Guesstimates & 0 \\
\hline Approximate or indirect method & 0.4 \\
\hline Sampling-based, low precision & 0.7 \\
\hline Sampling-based, high precision & 1 \\
\hline \multicolumn{2}{|l|}{$P / B$ and $Q / B$} \\
\hline Missing parameter (estimated by model) & 0 \\
\hline Guesstimates & 0.1 \\
\hline From other models & 0.2 \\
\hline Empirical relationship & 0.5 \\
\hline Similar group/species, similar system & 0.6 \\
\hline Similar group/species, same system & 0.7 \\
\hline Same group/species, similar system & 0.8 \\
\hline Same group/species, same system & 1 \\
\hline \multicolumn{2}{|l|}{ Diet composition } \\
\hline General knowledge of related group/species & 0 \\
\hline From other models & 0 \\
\hline General knowledge of the same group/species & 0.2 \\
\hline Qualitative diet composition study & 0.5 \\
\hline Quantitative, but limited diet composition study & 0.7 \\
\hline Quantitative, detailed diet composition study & 1 \\
\hline \multicolumn{2}{|l|}{ Catches } \\
\hline Guesstimates & 0 \\
\hline From other models & 0 \\
\hline FAO statistics & 0.2 \\
\hline National statistics & 0.5 \\
\hline Local study, low precision/incomplete & 0.7 \\
\hline Local study, high precision/complete & 1 \\
\hline
\end{tabular}


Table 2.21 Quality of data sources used in the food web model of the Great Lagoon.

\begin{tabular}{|c|c|c|c|c|}
\hline \multirow{2}{*}{ Component } & \multicolumn{4}{|c|}{ Score } \\
\hline & (Bio)mass & P/B; Q/B & diet & catches \\
\hline \multicolumn{5}{|l|}{ Pelagic: } \\
\hline Allochthonous POM input & 0.4 & & & \\
\hline Allochthonous DOM input & 0.4 & & & \\
\hline Phytoplankton & 1 & 0.7 & & \\
\hline Bacterioplankton & 0 & 0 & 0 & \\
\hline Protozooplankton & 0 & 0 & 0.2 & \\
\hline Rotifers & 0.7 & 0.5 & 0.2 & \\
\hline Non-predatory cladocerans & 0.7 & 0.5 & 0.2 & \\
\hline Copepods & 0.7 & 0.5 & 0.2 & \\
\hline Leptodora kindti & 0.4 & 0.5 & 0.2 & \\
\hline Mysids & 0 & 0.5 & 0.2 & \\
\hline \multicolumn{5}{|l|}{ Epiphytic: } \\
\hline Epiphytic algae & 0.7 & 0.5 & & \\
\hline Epiphytic bacteria and fungi & 0 & 0 & 0.2 & \\
\hline Protozooperiphyton & 0 & 0 & 0.2 & \\
\hline Mesozooperiphyton & 0.7 & 0.5 & 0.2 & \\
\hline Sessile macrozooperiphyton & 0.7 & 0.5 & 0.2 & \\
\hline Motile macrozooperiphyton & 0.7 & 0.5 & 0.2 & \\
\hline \multicolumn{5}{|l|}{ Benthic: } \\
\hline Emergent plants & 0.4 & 0.5 & & \\
\hline Submerged and floating-leaved plants & 0.4 & 0.5 & & \\
\hline Microphytobenthos & 0 & 0.1 & & \\
\hline Benthic bacteria and fungi & 0 & 0 & 0.2 & \\
\hline Benthic protozoans & 0 & 0 & 0.2 & \\
\hline Meiobenthos & 0.7 & 0.5 & 0.2 & \\
\hline Chironomus sp. larvae & 1 & 0.5 & 0.5 & \\
\hline Macrobenthic ostracods & 0.7 & 0.5 & 0.2 & \\
\hline Oligochaetes & 1 & 0.5 & 0.2 & \\
\hline Dreissena polymorpha & 1 & 1 & 0.2 & \\
\hline Other molluscs & 1 & 0.5 & 0.2 & \\
\hline Remaining zoobenthos & 0.7 & 0.5 & 0.2 & \\
\hline
\end{tabular}


The Szczecin Lagoon Ecosystem:

The Biotic Community of the Great Lagoon and its Food Web Model

Table 2.21 Quality of data sources used in the food web model of the Great Lagoon.

\begin{tabular}{|l|c|c|c|c|}
\hline \multirow{2}{*}{ Component } & \multicolumn{4}{|c|}{ Score } \\
\cline { 2 - 5 } & (Bio)mass & P/B; Q/B & diet & catches \\
\hline Ichthyofauna: & 0.4 & 0.5 & 1 & \\
\hline Larvae and fry of planktivorous fish & 0.7 & 0.5 & 1 & 0 \\
\hline Juvenile and adult planktivorous fish & 0.4 & 0.5 & 1 & \\
\hline Larvae and fry of benthivorous fish & 0.7 & 0.5 & 1 & 0.7 \\
\hline Juvenile and adult benthivorous fish & 0.4 & 0.5 & 1 & \\
\hline Larvae and fry of piscivorous fish & 0.7 & 0.5 & 1 & 0.7 \\
\hline Juvenile and adult piscivorous fish & & & & \\
\hline Birds: & 0.4 & 0.2 & 0.2 & \\
\hline Herbivorous birds & 0.4 & 0.2 & 0.2 & \\
\hline Molluscivorous birds & 0.4 & 0.2 & 0.2 & \\
\hline Omnivorous birds & 0.4 & 0.2 & 0.2 & \\
\hline Piscivorous birds & 38 & 36 & 31 & 3 \\
\hline $\mathbf{n}$ & 0.497 & 0.392 & 0.358 & 0.467 \\
\hline Average score & & & \\
\hline
\end{tabular}

\subsubsection{Comparison of the Great (Szczecin) Lagoon with Other Ecosystems}

The comparison, conducted in Part 1 of this work (Section 1.14), of the trophic status and biological characteristics of the Great (Szczecin) Lagoon and other areas was limited mainly to the southern Baltic's coastal lagoons and lakes, dominated by the riverine water regime, where influxes of the brackish Baltic water are of secondary importance only. The freshwater nature of the Lagoon's flora and fauna allowed also to carry out biocoenotic comparisons with inland water bodies, particularly with dam reservoirs and larger lakes. The comparisons showed the biomass and production of the Lagoon biota components analysed to be high or very high. During the period of study (1998-2002), the area experienced no serious environmental stress, whereby the ecosystem was capable of functioning efficiently. This was evidenced by the high ecological efficiency of the great majority of the communities studied, corresponding to the efficiency observed in other highly productive temperate water bodies. However, the fully informative comparison of production potential of the Lagoon with that of other water bodies is possible only with the modelling approach in which units of measurements, system 
structure, assumptions adopted, etc. are formalised, and the matter/energy flow in various systems balanced out. There are a substantial number of publications on food web models of aquatic ecosystems in various climatic zones, which increases the representativeness of comparative analyses. This section reviews those aquatic ecosystems for which food web models have been developed.

To narrow down the analysis to ecosystems with physical conditions similar to those in the Great Lagoon, comparisons were performed on lagoonor estuary-type water bodies, usually shallow and land-bound. Another prerequisite was that a model would adopt one year as unit time. Of the 68 aquatic ecosystem models described in the literature reviewed, the criteria were met by 20 ecosystems (one of which, the Pearl River Estuary, was analysed in two different periods of study) described in 16 publications (Table 2.22). The different ways of expressing weight of functional groups (wet weight, organic carbon, dry weight, ahs-free dry weight, organic nitrogen) used in the models were converted to organic carbon units using, whenever possible, conversion factors provided in the original papers; the remaining case, conversion factors published by Atkinson and Smith (1983) Vinogradov and Shushkina (1987), and Opitz (1996).

Although the ecosystems compared are situated in different regions of the world, all are located in the northern hemisphere. Eleven of them are in the temperate zone, the remaining 9 being confined to the tropical zone. Their size ranges extensively, from 3 to $72,600 \mathrm{~km}^{2}$ (Table 2.22), most covering from several tens to few hundred $\mathrm{km}^{2}$.

The ecosystems compared differed widely in their productivity. The primary production in the most oligotrophic of them amounted to as little as a several tens of $\mathrm{gC} \mathrm{m}^{-2} \mathrm{yr}^{-1}$ (the Pearl River estuary and some Gulf of Mexico lagoons), 3 thou. $\mathrm{gC} \mathrm{m}^{-2} \mathrm{yr}^{-1}$ being the primary production in the most eutrophic one (the Chiku Lagoon, Taiwan). Three quarters of the ecosystems showed net primary production (NPP) ranging within 100-1000 $\mathrm{gC} \mathrm{m}^{-2} \mathrm{yr}^{-1}$. NPP of the Great Lagoon was in this range, closer to its upper boundary (538 gC m-2 $\mathrm{yr}^{-1}$ ) (Fig. 2.15). Like in the Great Lagoon, the primary production in many systems was dominated by that of the phytoplankton, but some ecosystems (e.g., the Venice Lagoon) featured the phytobenthos as the major organic matter producer.

The ecosystems compared differed widely in terms of the zooplankton and zoobenthos production as well, the differences being 200-fold in the extreme cases. The Pearl River Estuary and the Tampamachoco Lagoon in the Gulf of Mexico supported the total production of zooplankton and macrozoobenthos of a few $\mathrm{gC} \mathrm{m}^{-2} \mathrm{yr}^{-1}$, whereas the Chiku Lagoon and Lake Nokouke in the Gulf of Guinea showed several hundred gC $\mathrm{m}^{-2} \mathrm{yr}^{-1}$ (Fig. 2.16). In a vast majority of the ecosystems compared, the combined 


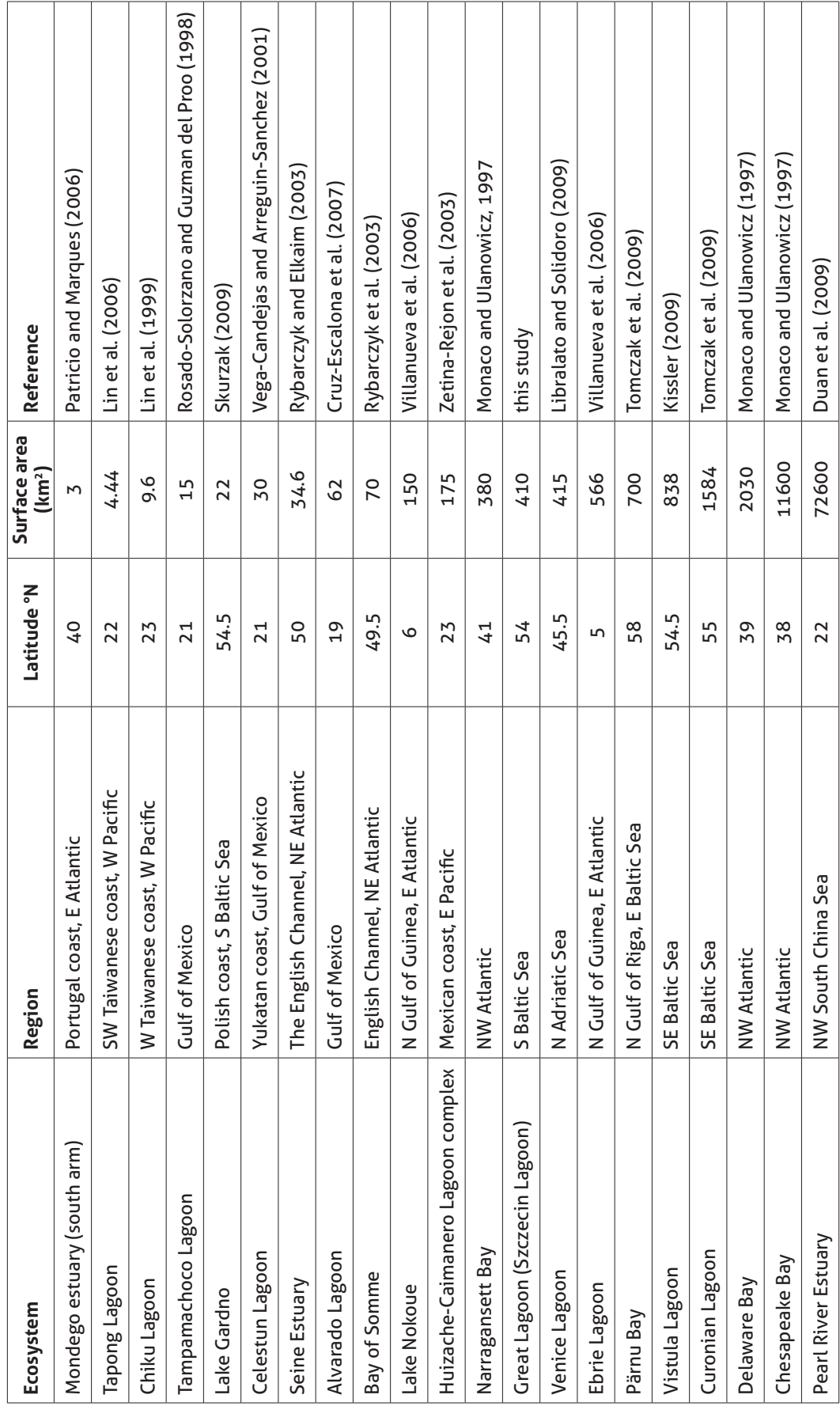




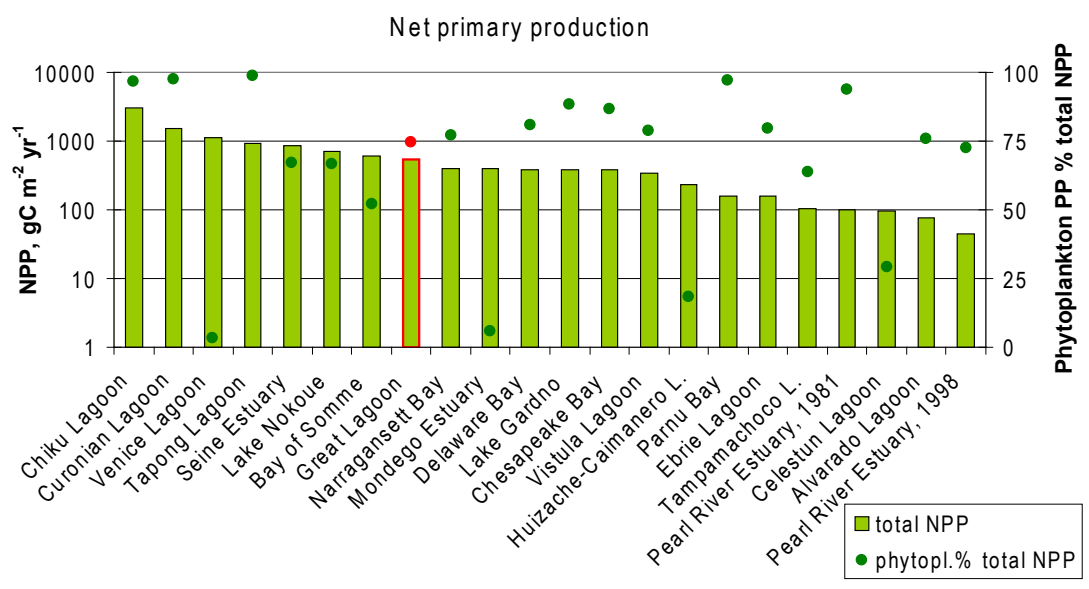

Figure 2.15 Primary production (NPP) in various lagoon- and estuary-type ecosystems, and contribution of phytoplankton production to total pelagic and benthic primary production.

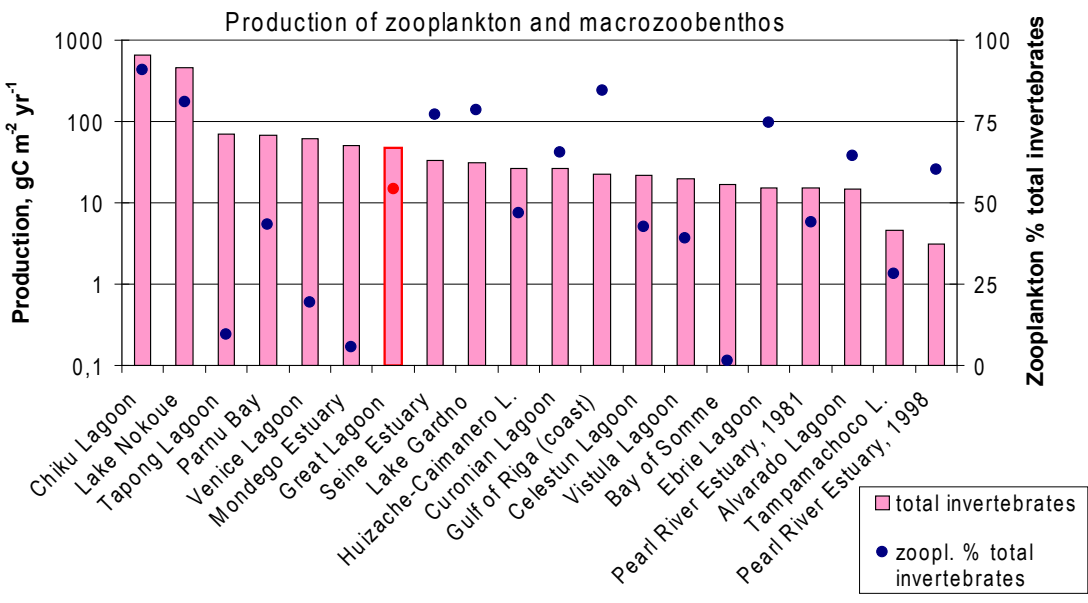

Figure 2.16 Combined production of zooplankton and macrozoobenthos in various lagoon- and estuary-type ecosystems, and contribution of zooplankton production to the combined zooplankton and macrozoobenthos production.

zooplankton and macrozoobenthos production was in the range of 10-100 $\mathrm{gC} \mathrm{m}^{-2} \mathrm{yr}^{-1}$. The invertebrate production in the Great Lagoon (47 $\mathrm{gC} \mathrm{m}^{-2} \mathrm{yr}^{-1}$ ) was in this range, too, the Lagoon being regarded as one of the more productive areas. The Lagoon zooplankton production was similar to 
that of the macrozoobenthos (25.5 and $21.5 \mathrm{gC} \mathrm{m}^{-2} \mathrm{yr}^{-1}$, respectively). Other ecosystems frequently show a distinct domination of production of one or the other ecological category.

The difference between the extreme values of fish production (800-fold) was still higher than that of the primary or invertebrate production. The lowest values were found in estuaries, particularly in the Seine Estuary (less than $0.1 \mathrm{gC} \mathrm{m}^{-2} \mathrm{yr}^{-1}$ ), the highest being reported for the Chiku Lagoon (close to $\left.75 \mathrm{gC} \mathrm{m}^{-2} \mathrm{yr}^{-1}\right)$. However, the fish production in most ecosystems ranged between 1 and $10 \mathrm{gC} \mathrm{m}^{-2} \mathrm{yr}^{-1}$ (Fig.2.17). In this case, too, the Great Lagoon was in the midrange $\left(4.4 \mathrm{gC} \mathrm{m}^{-2} \mathrm{yr}^{-1}\right)$.

As already discussed in Part 1, the Great Lagoon is characterised by particularly good conditions for a high fish production: a high production of the zooplankton and zoobenthos, i.e., the pool of natural food resources of fish, as well as a full availability of dietary items in the entire water column and throughout the surface of the bottom (no stratification, lack of anoxic zones). In addition, should edaphic and habitat conditions deteriorate locally, fish have a possibility to migrate to other areas of the Odra river mouth system.

Of all the parameters compared, the widest differences were observed in fish catches (Fig. 2.18). Those in the Celestun Lagoon in the Gulf of Mexico (0.026 $\mathrm{gC} \mathrm{m}^{-2} \mathrm{yr}^{-1}$ ) were almost 3000 times lower than in the Chiku Lagoon (76.4 $\mathrm{gC} \mathrm{m}^{-2} \mathrm{yr}^{-1}$ ). Most ecosystems (including the Great Lagoon) showed, however, a much narrower range of catch magnitude, between 0.1 and $1 \mathrm{gC} \mathrm{m}^{-2} \mathrm{yr}^{-1}$. Apart from the Baltic coastal water bodies, in few estuaries only the catches were limited to fish, molluscs and crustaceans being usually exploited as well.

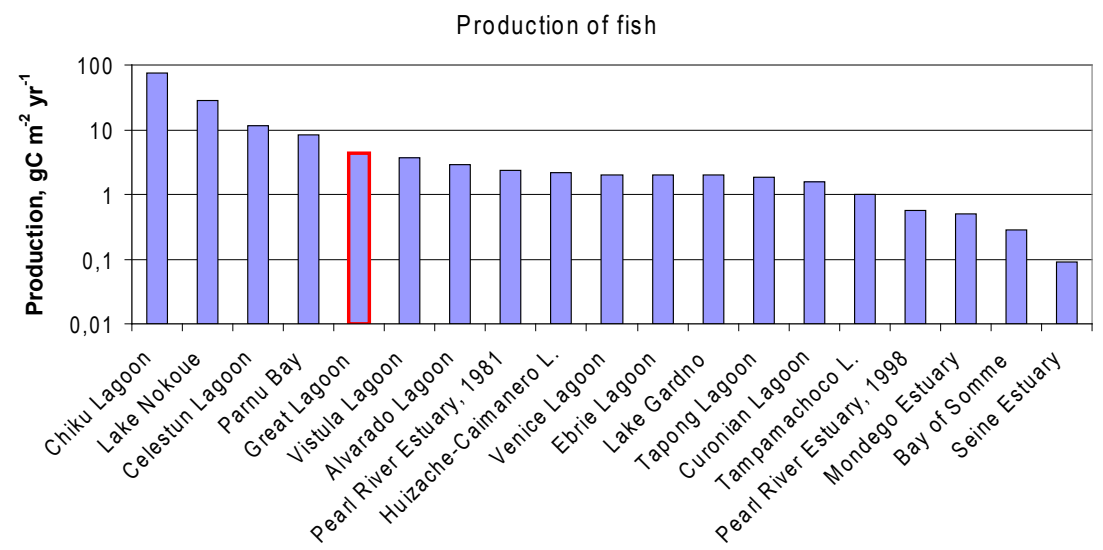

Figure 2.17 Fish production in various lagoon- and estuary-type ecosystems. 


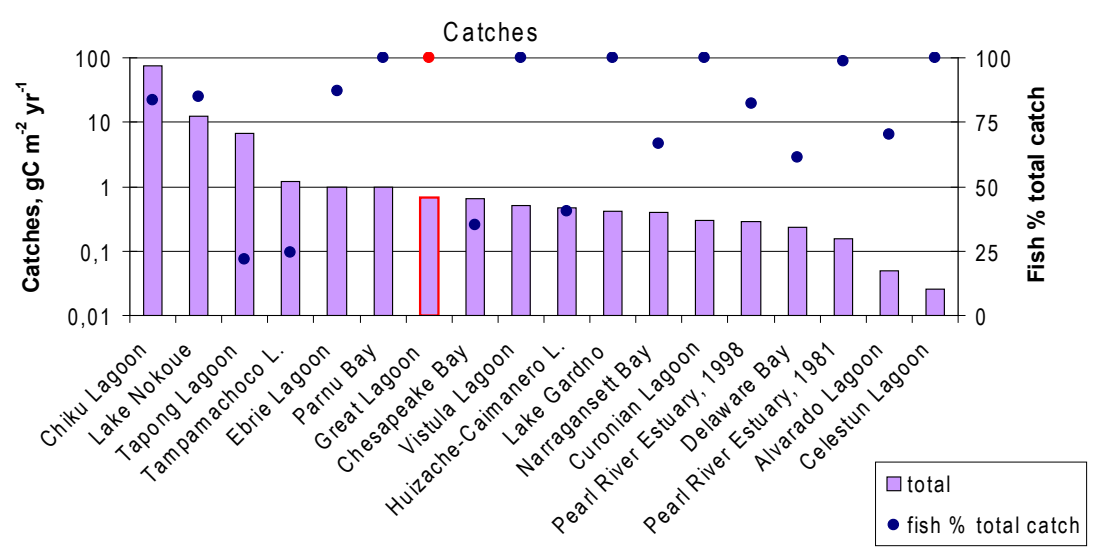

Figure 2.18 Total catches (landings) in various lagoon- and estuary-type ecosystems and contribution of fish to combined fish and shellfish catches.

In all the components compared, the highest production was typical of eutrophic water bodies from the tropical zone. The Chiku Lagoon inTaiwan was particularly productive. This is an ecosystem intensively fed with nutrients from the surrounding mangroves and culture ponds, in which the high primary production of the phytoplankton is very efficiently used in short trophic chains (the major fishery target are fish feeding on detritus and periphyton as well as oysters). In terms of the primary production, that of the Great Lagoon ecosystem was lower than the primary production in some most eutrophic tropical lagoons and some temperate lagoon-estuarine systems. However, the production of higher trophic levels, particularly of fish, and the fish catches in the Great Lagoon were only lower than those in warmer climates and in the Pärnu Bay in Estonia. As opposed to the latter, where a high proportion of catches is contributed by fish migrating from other Baltic areas to the Bay to spawn (herring), the Great Lagoon fisheries are based on the local fish fauna. Noteworthy is also the fact that the Great Lagoon supports no fish cultures, the total catches (landings) being the effects of exploitation of the wild stocks. The true magnitude of catches is doubtless higher than the official records, considering the by-catch of undersized fish and poaching (cf. Part 1, Sections 1.12 .3 and 1.14.11). This evidences a high ecological efficiency of the Great Lagoon ecosystem which allows a relatively large portion of energy assimilated by producers to be transferred to the highest trophic levels, even when the trophic chains are not extremely short, and climatic conditions are less favourable, compared to other ecosystems. 


\subsection{Summary}

The food web of the Great Lagoon (major basin of the Szczecin Lagoon) was modelled using a static model based on energy budget equations arranged from the bottom up to the top of a trophic pyramid. 45 components were differentiated in the food web. Five components involved autotrophs: the phytoplankton, emergent macrophytes, submerged and floating-leaved macrophytes, phytoperiphyton, and microphytobenthos. Nine components were associated with various forms of non-living organic matter ( 3 and 6 components consisted of allochthonous and autochthonous forms, respectively), the remaining 31 components being different functional/trophic groups of heterotrophs: 7 planktonic, 5 periphytic, 9 benthic, 6 formed by fish, and 4 by birds.

The autotrophic components and allochthonous sources of organic matter formed the base of the trophic pyramid. When constructing a network of energy flow between the components identified, biomass values of individual elements of the Great Lagoon biota were used in combination with the published values of their production rates $(P / B)$, food assimilation efficiency $(A E)$, and efficiency of utilisation of assimilated food for growth $\left(K_{2}\right)$. The expert knowledge on feeding of various animal groups was applied as well, derived either from research conducted in the Lagoon (the major fish species, larval Chironomus sp.) or from literature reviews. The model was parameterized using data on 26 heterotrophic components out of the 45 components of the entire food web. Parameterization was carried out so that the difference between the animal production values calculated by the model and determined from empirical biomass data and the P/B values would not exceed 1\%.

It should be mentioned that empirical biomasses of numerous components were only approximations and the bioenergetic indicators used were derived from studies conducted in other ecosystems, not infrequently on different species. For some components (bacteria, protists), no empirical data exist. It has then to be realised that the picture of the Great Lagoon food web produced by the model, although consistent with the measurement data and meeting the mass conservation requirement, is only an approximation of the true set of interactions; should other assumptions be adopted, a picture emerging would be more or less different that that painted in this work.

The net primary production of all the autotrophic Great Lagoon ecosystem components combined was estimated, for 1998-2002, at $538 \mathrm{gC} \mathrm{m}^{-2} \mathrm{yr}^{-1}$, the supply of allochthonous organic matter being estimated at $470 \mathrm{gC} \mathrm{m}^{-2} \mathrm{yr}^{-1}$. Thus, the total input of organic matter to the ecosystem amounted to about $1000 \mathrm{gC}$ $\mathrm{m}^{-2} \mathrm{yr}^{-1}$, almost half of which being obtained from the outside, from the Szczecin Lagoon catchment area. As the Great Lagoon is a flow-through water body, the supply of organic matter from the catchment is accompanied by constant export to the Pomeranian Bay in the Baltic Sea. According to the model estimates, more 
than $60 \%$ (about $300 \mathrm{gC} \mathrm{m}^{-2} \mathrm{yr}^{-1}$ ) of the allochthonous organic matter entering the Lagoon is exported unused. In addition, there was an export of about $50 \mathrm{gC} \mathrm{m}^{-2} \mathrm{yr}^{-1}$ of the organic matter produced in the Lagoon, hence the amount of the organic matter exported from the Lagoon was by about $1 / 4$ lower than the organic matter supply to the area.

The non-living organic matter was assigned to trophic level 1, similarly to all the primary producers. The highest number of food web components (almost all the invertebrates) were placed between trophic levels 2 and 3. A higher trophic position, between trophic levels 3 and 4, was occupied by Leptodora, sessile macrozooperiphyton, planktivorous fish and benthivorous fish and birds. The top predators (predatory fish as well as omni- and piscivorous birds) were found at trophic level 4-4.5.

In terms of biomass, vascular plants, primarily the emergent species (mainly reed), were the dominant group in the Great Lagoon. The macrophyte biomass was several times higher than the phytoplankton biomass and contributed almost $80 \%$ to the total biomass of the flora and fauna of the Lagoon (not including the biomass of bacteria and protists). The highest contribution to the animal biomass (about 1/4) was that of the zebra mussel. The zoobenthos accounted for almost $60 \%$ of the faunal biomass, fish, zooplankton, and zooperiphyton contributing 27,8 , and $5 \%$, respectively; the waterfowl accounted for as little as about $0.1 \%$. The biomass of fish larvae and fry contributed as little as $7 \%$ to the fish biomass in the ecosystem. Compared to the zoobenthos and the ichthyofauna, the zooplankton biomass was low, 7 times lower that the benthic fauna biomass and 3 times lower than the fish biomass. Thus, a large part of the flora and fauna biomass in the Great Lagoon was accumulated on the bottom, primarily in the littoral.

The dominant role in the energy flow in the Great Lagoon was played by unicellular organisms. Among the autotrophs, the most important was phytoplankton ( $74 \%$ of the net primary production), the heterotrophic part being dominated by bacteria. The consumption, secondary production, and respiration in both the water column and the bottom sediments were dominated by the bacterial components. Of about $1000 \mathrm{gC} \mathrm{m}^{-2} \mathrm{yr}^{-1}$ of organic matter supplied to the system and available to the consumers, heterotrophs respired about $580 \mathrm{gC} \mathrm{m}^{-2} \mathrm{yr}^{-1}$. Of that heterotrophs' respiration, bacteria used more than $60 \%$, further $10 \%$ being utilised by protists. Thus, the contribution of metazoan animals to the heterotrophic utilisation of organic matter supply amounted to less than $30 \%$.

The benthic and the planktonic communities played comparable roles in the overall budget of the matter and energy flow in the ecosystem. The zoobenthos and the zooplankton utilised 46 and $47 \%$ of the organic matter used by all heterotrophs in the system, respectively, the zooperiphyton and fish using 4 and $3 \%$, respectively. The higher biomass of benthic organisms was balanced by a higher metabolic rate of the planktonic organisms. 
From the standpoint of fisheries management, it may be interesting to compare the production of macrozoobenthos and the crustacean zooplankton, as the two groups are the basic food of non-predatory fish. The macrozoobenthos production in the Great Lagoon was estimated at about $22 \mathrm{gC} \mathrm{m}^{-2} \mathrm{yr}^{-1}$, the crustacean zooplankton production amounting to about $20 \mathrm{gC} \mathrm{m} \mathrm{m}^{-2}$. The two values are similar; in this context it may be surprising to find a substantial (several-fold) domination of benthivorous over planktivorous fish in the catches. An explanation of this apparent contradiction is the fact that a high proportion of the crustacean zooplankton production is consumed by larvae and fry of all the fish species, including benthivores and predators. The amount of food consumed by larvae and fry of all fish categories was almost 10 times that consumed by juvenile and adult planktivorous fish. An additional factor is the zooplankton export from the Lagoon to the Pomeranian Bay, the export accounting for $10-30 \%$ of the crustacean zooplankton production.

The Great Lagoon ecosystem produced about $420 \mathrm{gC} \mathrm{m}^{-2} \mathrm{yr}^{-1}$ of non-living organic matter in the form of faeces and remains of plants and animals. Together with the allochthonous organic matter, this pool formed a substantial food resource for decomposers. The detritus consumption in the Lagoon was estimated at about $590 \mathrm{gC} \mathrm{m}^{-2} \mathrm{yr}^{-1}$ and was similar to the biomass consumption estimated at about $570 \mathrm{gC} \mathrm{m}^{-2} \mathrm{yr}^{-1}$. The detritus consumption was dominated (about $75 \%$ ) by bacteria.

The model of the Great Lagoon food web developed allows to analyse the utilisation of production of various components in the ecosystem (the so-called ecotrophic efficiency). Production of most heterotrophic components was utilised to a high extent (80-95\%). Low ecotrophic efficiency (30-70\%) was typical of molluscs (including the zebra mussel) and sessile macrozooperiphyton, which can be explained by efficient protection against predation afforded by shells and exoskeletons. On the other hand, difficult to explain is the relatively low degree $(55 \%)$ of utilisation of the oligochaete production. Perhaps those animals, while living among sediment particles, are better protected from predation and are prone to natural mortality much more than other organisms. However, a too high oligochaete production assumed in the model cannot be ruled out. The relatively high proportion of unused production of predatory fish (more than 30\%), called the "additional mortality" in the model, may be an effect of incomplete catch reports, and may point out to the real catches being twice those officially reported. A particularly low ecotrophic efficiency was shown by the vascular plants, especially the emergent macrophytes, an otherwise wellknown effect.

The ecological indicators that can be calculated for the entire Great Lagoon ecosystem using the model (e.g., the gross primary production to total community respiration ratio close to unity) point out to a considerable maturity of the system. Compared to 20 other ecosystems, the primary production of 
the Great Lagoon was lower than that in some most fertile tropical lagoons and some lagoon-estuarine temperate systems. However, in terms of higher trophic level production, particularly that of fish and fish catches, the Great Lagoon ecosystem scored less only than systems from warmer climatic regimes and the Pärnu Bay in Estonia. This comparison provides evidence of a high ecological efficiency of the Great Lagoon and Pärnu Bay ecosystems, which allows to transfer a relatively high portion of energy assimilated by the producers to the highest trophic levels, even at climatic conditions that are less favourable than those in other ecosystems. 